\title{
Copper(II) Perfluorinated Carboxylate Complexes with Small Aliphatic Amines as Universal Precursors for Nanomaterial Fabrication
}

\author{
Iwona B. Szymańska *(D), Katarzyna Madajska $\mathbb{D}^{\mathbb{D}}$, Aleksandra Butrymowicz $\mathbb{D}^{\mathrm{D}}$ and Magdalena Barwiołek \\ Faculty of Chemistry, Nicolaus Copernicus University in Torun, Gagarina 7, 87-100 Torun, Poland; \\ 502533@doktorant.umk.pl (K.M.); aleksandra.butrymowicz@doktorant.umk.pl (A.B.); \\ mbarwiolek@umk.pl (M.B.) \\ * Correspondence: pola@umk.pl; Tel.: +48-56611-4317
}

check for

updates

Citation: Szymańska, I.B.; Madajska, K.; Butrymowicz, A.; Barwiołek, M. Copper(II) Perfluorinated

Carboxylate Complexes with Small Aliphatic Amines as Universal Precursors for Nanomaterial

Fabrication. Materials 2021, 14, 7451. https://doi.org/10.3390/ma14237451

Academic Editor: Piotr Smoleński

Received: 2 November 2021

Accepted: 30 November 2021

Published: 4 December 2021

Publisher's Note: MDPI stays neutral with regard to jurisdictional claims in published maps and institutional affiliations.

Copyright: (c) 2021 by the authors. Licensee MDPI, Basel, Switzerland. This article is an open access article distributed under the terms and conditions of the Creative Commons Attribution (CC BY) license (https:// creativecommons.org/licenses/by/ $4.0 /)$.

\begin{abstract}
Copper(II) carboxylate compounds with ethylamine and isopropylamine of the general formula $\left[\mathrm{Cu}_{2}\left(\mathrm{RNH}_{2}\right)_{2}\left(\mu-\mathrm{O}_{2} \mathrm{CR}_{\mathrm{f}}\right)_{4}\right]$, where $\mathrm{R}=\mathrm{Et}$, ${ }^{\mathrm{i}} \mathrm{Pr}$, and $\mathrm{R}_{\mathrm{f}}=\mathrm{C}_{\mathrm{n}} \mathrm{F}_{2 \mathrm{n}+1}, \mathrm{n}=1-6$, were characterised in the condensed and gas phases by electron impact mass spectrometry (EI MS), IR spectroscopy, and thermal analysis. A mass spectra analysis confirmed the presence of metallated species in the gas phase. Among the observed fragments, the pseudomolecular ions $\left[\mathrm{Cu}_{2}\left(\mathrm{RNH}_{2}\right)_{2}\left(\mu-\mathrm{O}_{2} \mathrm{CR}_{\mathrm{f}}\right)_{3}\right]^{+}$were found, which suggests the dimeric structure of the studied complexes with axially N-coordinated ethyl- or isopropylamine molecules and bridging perfluorinated carboxylates. TGA studies demonstrated that copper transfer to the gas phase occurs even under atmospheric pressure. The temperature range of the $\left[\mathrm{Cu}_{2}\left(\mathrm{RNH}_{2}\right)_{2}\left(\mu-\mathrm{O}_{2} \mathrm{CR}_{\mathrm{f}}\right)_{4}\right]$ and other copper carriers detection, observed in variable temperature infrared spectra, depends on the type of amine. The possible mechanisms of the decomposition of the tested compounds are proposed. The copper films were produced without additional reducing agents despite using $\mathrm{Cu}$ (II) CVD precursors in the chemical vapor deposition experiments. The layers of the gel-like complexes were fabricated in both spin- and dip-coating experiments, resulting in copper or copper oxide materials when heated. Dinuclear copper(II) carboxylate complexes with ethyl- and isopropylamine $\left[\mathrm{Cu}_{2}\left(\mathrm{RNH}_{2}\right)_{2}\left(\mu-\mathrm{O}_{2} \mathrm{CR}_{\mathrm{f}}\right)_{4}\right]$ can be applied for the formation of metal or metal oxide materials, also in the nanoscale, by vapour and 'wet' deposition methods.
\end{abstract}

Keywords: Copper(II); ethylamine; isopropylamine; perfluorinated carboxylates; EI-MS; chemical vapor deposition; spin- and dip-coating precursors

\section{Introduction}

Nowadays, copper compounds are applied as antifungal and antibacterial coatings, catalysts, or in the assembly of chemical and electrochemical sensors. [1]. Additionally, organic-inorganic hybrid compounds containing copper-bis(triazole) complexes and Keggin-type polyoxometalates (POMs) showed electrocatalytic activities towards the reduction of nitrites [2]. Copper-halide compounds may be employed as new light-emitting materials [3] and in photovoltaic application [4].

To the best of our knowledge, the literature data concerning $\mathrm{Cu}$ (II) carboxylate compounds with $\mathrm{EtNH}_{2}$ are limited to the dicarboxylate $\left[\mathrm{Cu}\left(\mathrm{EtNH}_{2}\right)_{2}\left(\mathrm{C}_{2} \mathrm{O}_{4}\right)\right]$ derivative [5]. It was synthesised by adding ethylamine to a chloroform hemihydrate $\left[\mathrm{Cu}\left(\mathrm{C}_{2} \mathrm{O}_{4}\right)\right] 0.5 \mathrm{H}_{2} \mathrm{O}$ solution, and its spectral, magnetic, and thermal properties were characterised. Information on copper compounds containing carboxylates and triethylamine of the following formula $\left[\mathrm{Cu}_{2}\left(\mathrm{NEt}_{3}\right)_{2}\left(\mu-\mathrm{O}_{2} \mathrm{C}^{\mathrm{t}} \mathrm{Bu}\right)_{4}\right][6]$ and on copper polymers $\left[\mathrm{Cu}_{2}\left(\mathrm{Et}_{3} \mathrm{NH}\right)\left(\mathrm{syn}, \mathrm{syn}-\eta^{1}: \eta^{1}: \mu-\right.\right.$ $\left.\mathrm{O}_{2} \mathrm{CR}\right)_{4}\left(\right.$ anti,anti- $\left.\left.\eta^{1}: \eta^{1}: \mu-\mathrm{O}_{2} \mathrm{CR}\right)\right]_{\mathrm{n}}$, where $\mathrm{R}=\mathrm{Me}$ or $\mathrm{H}$ and dimers such as $\left[\mathrm{Cu}_{2}\left(\mathrm{Et}_{2} \mathrm{NH}_{2}\right)_{2}\right.$ (syn,syn- $\left.\left.\eta^{1}: \eta^{1}: \mu-\mathrm{O}_{2} \mathrm{CMe}\right)_{4}\left(\text { anti- } \eta^{1}-\mathrm{O}_{2} \mathrm{CMe}\right)_{2}\right]$ and $\left[\mathrm{Cu}_{2}\left(\mathrm{Et}_{3} \mathrm{NH}\right)_{2}\left(\text { syn,syn- } \eta^{1}: \eta^{1}: \mu-\mathrm{O}_{2} \mathrm{CPh}\right)_{4}\right.$ (anti- $\left.\eta^{1}-\mathrm{O}_{2} \mathrm{CPh}\right)_{2}$ ] can also be found in the literature [7]. Furthermore, copper(II) complexes with aromatic carboxylates with a substituent on the benzene ring $\left(-\mathrm{CH}_{3},-\mathrm{Cl}\right.$, 
or $-\mathrm{NO}_{2}$ ) and diethylamine or dipropylamine have been previously described [8]. The possibility of tert-butylamine copper(II) carboxylate complexes formation by applying tert-butyl isocyanate was described in our previous paper [9]. Therefore, the applicability of this reaction type for the preparation of ethyl- and isopropylamine $\mathrm{Cu}$ (II) carboxylate compounds was a noteworthy issue. Working with isocyanates is easier due to their higher boiling points (e.g., for ethylamine. b.p $=16.6^{\circ} \mathrm{C}$ so it is gaseous at room temperature, while for ethyl isocyanate, $\mathrm{b} \cdot \mathrm{p}=60^{\circ} \mathrm{C}$ ).

The copper(II) carboxylate complexes with tert-butylamine were applied as $\mathrm{Cu} C V D$ precursors for the fabrication of copper nanomaterials fabrication. It is worth emphasizing that even with the first CVD experiments, all the $\left[\mathrm{Cu}_{2}\left({ }^{\mathrm{t}} \mathrm{BuNH}_{2}\right)_{2}\left(\mu-\mathrm{O}_{2} \mathrm{CR}_{\mathrm{f}}\right)_{4}\right]\left(\mathrm{R}_{\mathrm{f}}=\mathrm{C}_{\mathrm{n}} \mathrm{F}_{2 \mathrm{n}+1}\right.$, $\mathrm{n}=1-6)$ complexes led to copper covers with no reducing agent despite those containing copper in the second oxidation state $[9,10]$. Over the past few years, the synthesis and research of analogous compounds have been continued and expanded. As a result, compounds with the formulas: $\left[\mathrm{Cu}_{2}\left({ }^{\mathrm{t}} \mathrm{BuNH}_{2}\right)_{2}\left(\mu-\mathrm{O}_{2} \mathrm{CC}_{2} \mathrm{~F}_{5}\right)_{4}\right],\left[\mathrm{Cu}_{2}\left({ }^{\mathrm{s}} \mathrm{BuNH}\right)_{2}\right)_{2}(\mu-$ $\left.\left.\mathrm{O}_{2} \mathrm{CC}_{2} \mathrm{~F}_{5}\right)_{4}\right],\left[\mathrm{Cu}_{2}\left(\mathrm{EtNH}_{2}\right)_{2}\left(\mu-\mathrm{O}_{2} \mathrm{CC}_{2} \mathrm{~F}_{5}\right)_{4}\right]$, and $\left[\mathrm{Cu}_{2}\left(\mathrm{EtNH}_{2}\right)_{2}\left(\mu-\mathrm{O}_{2} \mathrm{CC}_{3} \mathrm{~F}_{7}\right)_{4}\right]$ were synthesized and tested for interactions with low-energy electrons and a possible use in the focused electron beam induced deposition (FEBID) method. Due to their gel form, compounds could be directly deposited on a surface which allowed the studying them with surface science tools in a vacuum environment $[11,12]$.

The obtained new compounds $\left[\mathrm{Cu}_{2}\left(\mathrm{RNH}_{2}\right)_{2}\left(\mu-\mathrm{O}_{2} \mathrm{CR}_{\mathrm{f}}\right)_{4}\right]$, where $\mathrm{R}=\mathrm{Et}, \mathrm{R}_{\mathrm{f}}=\mathrm{CF}_{3}$, $\mathrm{C}_{4} \mathrm{~F}_{9}, \mathrm{C}_{5} \mathrm{~F}_{11}, \mathrm{C}_{6} \mathrm{~F}_{13}$; and $\mathrm{R}={ }^{\mathrm{i}} \mathrm{Pr}, \mathrm{R}_{\mathrm{f}}=\mathrm{CF}_{3}, \mathrm{C}_{2} \mathrm{~F}_{5}, \mathrm{C}_{3} \mathrm{~F}_{7}, \mathrm{C}_{4} \mathrm{~F}_{9}$, form blue gels under normal conditions. Therefore, we want to examine how the $\mathrm{N}$-donor ligand modification $\left(\mathrm{EtNH}_{2}\right.$ vs. ${ }^{i} \mathrm{PrNH}_{2}$ ) can affect the physicochemical properties of complexes, mainly their thermal stability and suitability for the generation of metallated volatile species. Due to a good solubility of the compounds, we have tested the applicability of these metal-organic compounds application in 'wet' coating methods. The literature data indicate that using spin- or dipcoating techniques and then heating the deposited precursors, metal or metal oxide layers at a thickness from a few tens up to several hundred nanometers can be obtained $[13,14]$ in a low-cost process because they do not require complicated technical and hence, expensive equipment.

In the case of copper compounds, 'wet' deposition methods are the most often used for the copper(II) oxide materials formation. They are applied as heterogenic catalysts, in electrochemical cells for the $\mathrm{Li}_{2} \mathrm{CuO}_{2}$ preparation, as electrodes in photoelectrochemical PEC cells, and for the construction of gas sensors and high-temperature superconductors. Moreover, the obtained copper materials can be used for example, in electronic [15,16], plasmonics [17,18], catalysis [19-21], and as antibacterial agents [22,23]. In dip and spin-coating methods, systems based on copper carboxylates were applied. For example, the ethanolic solution of the $\left[\mathrm{Cu}_{2}\left(\mathrm{H}_{2} \mathrm{O}\right)_{2}\left(\mu-\mathrm{O}_{2} \mathrm{CCH}_{3}\right)_{4}\right]$ complex in the presence of monoethanolamine (MEA) was used for the copper(II) oxide layer formation by the dip-coating method. The covers were obtained by heating the dip-coated films in the air at $723 \mathrm{~K}$ [24].

Furthermore, the anhydrous copper(II) acetate dissolved in ethanol was applied in a spin-coating process on glass substrates. The final cover $\left(\mathrm{Cu}_{2} \mathrm{O}\right)$ was fabricated by heating at $423 \mathrm{~K}$ under nitrogen. Moreover, copper carboxylate compounds were used for the metallic copper layer formation by a dip-coating method. The solution contained copper acetate dihydrate and diethanolamine (DEA) in 2-propanol. The molar ratio of DEA to $\mathrm{Cu}^{2+}$ was $2: 1$, but the concentration of the obtained sol ranged from 0.25 to $1.5 \mathrm{~mol} / \mathrm{dm}^{3}$. The copper coatings were prepared by heating under nitrogen deposited on glass substrates materials [25]. The results of the complexing agents and surfactants addition aimed at improving the deposition process were described in literature while, for the compounds studied herein, the perfluorinated carboxylates as the complexing surfactants form the integral part of the molecules (vide infra).

In this paper, the synthesis, characteristics by electron impact mass spectrometry, infrared (IR) spectroscopy, variable temperature infrared spectroscopy (VT IR), thermal analysis, and applications of $\left[\mathrm{Cu}_{2}\left(\mathrm{RNH}_{2}\right)_{2}\left(\mu-\mathrm{O}_{2} \mathrm{CR}_{\mathrm{f}}\right)_{4}\right]$ complexes, where $\mathrm{R}=\mathrm{Et}$, ${ }^{\mathrm{i}} \mathrm{Pr}$; 
$\mathrm{R}_{\mathrm{f}}=\mathrm{C}_{\mathrm{n}} \mathrm{F}_{2 \mathrm{n}+1}, \mathrm{n}=1-6$, in the Chemical Vapour Deposition process as well as in spinand dip- coating methods will be described.

\section{Experimental}

\subsection{Materials}

$\mathrm{CuCO}_{3} \cdot \mathrm{Cu}(\mathrm{OH})_{2}$, ethyl isocyanate EtNCO $(97 \%)$, isopropyl isocyanate ${ }^{\mathrm{i}} \mathrm{PrNCO}(98 \%)$, $\mathrm{CF}_{3} \mathrm{COOH}$ and $\mathrm{C}_{6} \mathrm{~F}_{13} \mathrm{COOH}(99 \%) ; \mathrm{C}_{3} \mathrm{~F}_{7} \mathrm{COOH}(98 \%)$; and $\mathrm{R}_{\mathrm{f}} \mathrm{COOH}(97 \%) \mathrm{R}_{\mathrm{f}}=\mathrm{C}_{\mathrm{n}} \mathrm{F}_{2 \mathrm{n}+1}$; $\mathrm{n}=2,4,5$; were purchased from Sigma-Aldrich, acetonitrile (99.9\%) from Honeywell, tetrahydrofuran (p.a.) from Avantor Performance Materials Poland S.A., ethanol (99.6\%) from Bioetanol AEG, $\mathrm{HF}(40 \%)$ and $\mathrm{HNO}_{3}(65 \%)$ from Chempur and $\mathrm{Si}(111)$ from Institute of Economic Materials Technology in Warsaw. All reagents were used as received. Copper(II) carboxylates $\left[\mathrm{Cu}\left(\mu-\mathrm{O}_{2} \mathrm{CR}_{\mathrm{f}}\right)_{2}\right]$, where $\mathrm{R}_{\mathrm{f}}=\mathrm{C}_{\mathrm{n}} \mathrm{F}_{2 \mathrm{n}+1}, \mathrm{n}=1-6$, were prepared as reported [26].

\subsection{Instrumentation}

Mass spectra using a Finnigan MAT 95 mass spectrometer, Waltham, MA, USA and electron impact (EI) ionisation method were registered over the temperature range of 303-623 K. The isotopic patterns were simulated by using the shareware software Wsearch32. IR spectra were measured on a Vertex 70V spectrometer (Bruker Optik, Leipzig, Germany) using a reflective-single reflection diamond ATR unit $\left(200-4000 \mathrm{~cm}^{-1}\right)$ or using a PerkinElmer Spectrum 2000 spectrometer (Waltham, MA, USA) over $400-4000 \mathrm{~cm}^{-1}$ in $\mathrm{KBr}$ and over $200-400 \mathrm{~cm}^{-1}$ in PE, with a medium slit width and a peak resolution of $2.0 \mathrm{~cm}^{-1}$. The $\mathrm{Cu}$ content was determined with an iCE3300 FL atomic absorption spectrometer Thermo Fisher Scientific, Waltham, MA, USA. The content of $\mathrm{C}$ and $\mathrm{H}$ was found out with a Vario MACRO CHN ELEMENTAR Analysensysteme GmbH, Langenselbold, Germany. Thermal studies (TGA/DTA) were performed on an SDT 2960 TA analyser (New Castle, DE, USA) (dry $\mathrm{N}_{2}$; heating rate $2.5 \mathrm{~K} / \mathrm{min}$, heating range up to 598-692 K; sample mass 7-13 mg). Variable temperature infrared spectra (VT IR) were registered using a PerkinElmer Spectrum 2000 spectrometer (Waltham, MA, USA) over $400-4000 \mathrm{~cm}^{-1}$ with a medium slit width and a peak resolution of $2.0 \mathrm{~cm}^{-1}$. The glass vessel with the precursor sample ( 100 mg) was placed in the homemade reactor tube and heated (from 303 to $753 \mathrm{~K}$ ) under a dynamic vacuum ( $p=10^{-1} \mathrm{mbar}$ ). IR spectra of vapours collected at selected temperatures were registered. Optical images of the deposited layers were made using an optical microscope RamanMicro 200 PerkinElmer (Waltham, MA, USA). The morphology and composition studies of obtained materials were performed using scanning electron microscopy: SEM-LEO 1430VP, Ltd., Cambridge, UK (operating voltage $28 \mathrm{kV}$ ) equipped with an energy dispersive X-ray spectrometer (EDS) Quantax 200 with detector XFlash 4010 (Bruker AXS microanalysis GmbH, Berlin, Germany). SEM images were registered using Quanta 3D FEG (FEI, Hillsboro, OR, USA). Transmission electron microscopy (TEM G2 F20X-Twin $200 \mathrm{kV}$ FEI, Hillsboro, OR, USA) was used to confirm the composition of the deposited materials. To identify the chemical elements, energy-dispersive X-ray (EDX, RTEM model SN9577, 134eV, EDAX, FEI, Hillsboro, OR, USA) spectra and selected area (electron) diffraction pattern were recorded.

\subsection{Chemical Vapour Deposition Parameters}

CVD deposition experiments were conducted using the homemade horizontal hotwall CVD reactor. Copper films were grown on $\mathrm{Si}(111)$ substrates in argon atmosphere within $60 \mathrm{~min}$, at $p=10^{-1}$ mbar. Silicon substrate surfaces were previously cleaned according to the literature procedure $[10,27]$. The process parameters were selected based on the data obtained from the thermal analysis and the results of the VT IR.

\subsection{Spin- and Dip-Coating Parameters}

Precursors were dissolved either in tetrahydrofuran (THF) or acetonitrile, forming an almost saturated solution, and deposited on $\mathrm{Si}(111)$ substrates by the spin-coating 
technique using a spin-coater (Laurell 650SZ) and by the dip-coating method using a dip-coater (QPI-168 Qualtech Products Industry).

The spin coating was a multistage process, the spin speed was varied from 600 to $3000 \mathrm{rpm}$, and the process time was changed over the range 4-60 s. The SC (spin-coated) materials were obtained in four stages program. Each program consisted of three steps with variable spin speed and one drying stage ( $3000 \mathrm{rpm}, 1 \mathrm{~min}$ ). The solution introduction on the substrate and all deposition procedures for each layer were repeated twice.

The dip-coating parameters were the following: the withdraw rate $20-80 \mathrm{~mm} / \mathrm{min}$, the immersion rate $60-80 \mathrm{~mm} / \mathrm{min}$, the immersion time 5,10 , or $120 \mathrm{~s}$, and the coating count 5-80.

The films obtained by both techniques were characterised and next heated in a tube furnace PRW 55 Czylok equipped with a quartz reactor with steel gas heads. The process was carried out under a nitrogen atmosphere $\left(1 \mathrm{~cm}^{3} / \mathrm{min}\right)$ at $673 \mathrm{~K}$ for $3 \mathrm{~h}$. Then deposits were cooled down under nitrogen for $3 \mathrm{~h}$. The heating temperature of the films was selected based on the thermal analysis results.

\subsection{Synthesis of $\left.\left[\mathrm{Cu}_{2}\left(\mathrm{RNH}_{2}\right)_{2}\left(\mu-\mathrm{O}_{2} \mathrm{CR}_{f}\right)_{4}\right]\right)(\mathbf{1 - 1 0})$}

In the general procedure, copper(II) carboxylate $\left[\mathrm{Cu}_{2}\left(\mu-\mathrm{O}_{2} \mathrm{CR}_{\mathrm{f}}\right)_{4}\right]\left(1 \cdot 10^{-3} \mathrm{~mol}\right.$ for $\mathrm{R}_{\mathrm{f}}=\mathrm{CF}_{3}(\mathbf{1})$ or $0.5 \cdot 10^{-3} \mathrm{~mol}$ for $\mathrm{R}_{\mathrm{f}}=\mathrm{C}_{4} \mathrm{~F}_{9}, \mathrm{C}_{5} \mathrm{~F}_{11}, \mathrm{C}_{6} \mathrm{~F}_{13}(4-6)$ and $\mathrm{R}=\mathrm{Et} ; 1 \cdot 10^{-3} \mathrm{~mol}$ for $\mathrm{R}_{\mathrm{f}}=\mathrm{CF}_{3}, \mathrm{C}_{2} \mathrm{~F}_{5}, \mathrm{C}_{3} \mathrm{~F}_{7}, \mathrm{C}_{4} \mathrm{~F}_{9}$ and $\mathrm{R}={ }^{\mathrm{i}} \operatorname{Pr}(7-10)$ ) was dissolved in $20 \mathrm{~cm}^{3}$ acetonitrile, and ethyl or isopropyl isocyanate $1 \cdot 10^{-3} \mathrm{~mol}$ or $0,5 \cdot 10^{-3} \mathrm{~mol}$ was dropped in, respectively. The obtained reaction mixture was stirred for $4 \mathrm{~h}$, on air, at room temperature for $R_{f}=C_{n} F_{2 n+1}$, where $n=1-5$ but at $303 \mathrm{~K}$ for $R_{f}=C_{6} F_{13}(6)$. Next, the solution was filtered, and the final product was isolated by solvent evaporation at the reduced pressure in argon. The obtained complexes were blue, gel-like solids, stable on air, which should only be moisture-protected during the storage. Yields ranged between $40-85 \%$ for $\mathrm{R}=\mathrm{Et}$ and $62-72 \%$ for $\mathrm{R}={ }^{\mathrm{i}} \mathrm{Pr}$. No crystals suitable for an $\mathrm{X}$-ray structure determination were obtained.

The synthesis of compounds $\left[\mathrm{Cu}_{2}\left(\mathrm{EtNH}_{2}\right)_{2}\left(\mu-\mathrm{O}_{2} \mathrm{CC}_{2} \mathrm{~F}_{5}\right)_{4}\right](2)$ and $\left[\mathrm{Cu}_{2}\left(\mathrm{EtNH}_{2}\right)_{2}(\mu-\right.$ $\left.\left.\mathrm{O}_{2} \mathrm{CC}_{3} \mathrm{~F}_{7}\right)_{4}\right]$ (3) has been described by us earlier [11,12]. The complexes (2) and (3) were prepared and tested for interactions with low-energy electrons.

The results of elementary analyses and spectroscopic data are given below:

$\left[\mathrm{Cu}_{2}\left(\mathrm{EtNH}_{2}\right)_{2}\left(\mu-\mathrm{O}_{2} \mathrm{CCF}_{3}\right)_{4}\right](\mathbf{1}) \mathrm{C}_{12} \mathrm{H}_{14} \mathrm{Cu}_{2} \mathrm{~F}_{12} \mathrm{~N}_{2} \mathrm{O}_{8}$ (calc./found) \% Cu 19.0/18.3, C 21.53/21.72, H 2.11/2.28; EI-MS T = $305 \mathrm{~K}(\mathrm{~m} / \mathrm{z}, \mathrm{RI} \%)\left[\mathrm{C}_{2} \mathrm{H}_{7} \mathrm{~N}\right]^{+} .(45,45) ;\left[\mathrm{Cu}\left(\mathrm{EtNH}_{2}\right)\left(\mathrm{O}_{2} \mathrm{CCF}_{3}\right)\right]^{+}$ $(221,11) ;\left[\mathrm{Cu}_{2}\left(\mathrm{O}_{2} \mathrm{CCF}_{3}\right)\right]^{+}(239,100) ;\left[\mathrm{Cu}_{2}\left(\mathrm{EtNH}_{2}\right)\left(\mathrm{O}_{2} \mathrm{CCF}_{3}\right)\right]^{+}(284,5) ;\left[\mathrm{Cu}_{2}\left(\mathrm{O}_{2} \mathrm{CCF}_{3}\right)_{2}\right]^{+}$. $(352,66) ;\left[\mathrm{Cu}_{2}\left(\mathrm{EtNH}_{2}\right)_{2}\left(\mathrm{O}_{2} \mathrm{CCF}_{3}\right)_{3}\right]^{+}(555,3) ; \mathrm{IR}(\mathrm{KBr}, 3253,3084,2992,2835,2743,2628$, 2520, 2046, 1672, 1518, 1478, 1436, 1402, 1337, 1202, 1143, 1045, 996, 842, 797, 726, 612, 600, 520, 422; PE 426, 382, $347 \mathrm{~cm}^{-1}$ ).

Data for copper complexes (2) and (3) have been published previously [11,12].

$\left[\mathrm{Cu}_{2}\left(\mathrm{EtNH}_{2}\right)_{2}\left(\mu-\mathrm{O}_{2} \mathrm{CC}_{2} \mathrm{~F}_{5}\right)_{4}\right](2) \mathrm{C}_{16} \mathrm{H}_{14} \mathrm{Cu}_{2} \mathrm{~F}_{20} \mathrm{~N}_{2} \mathrm{O}_{8}$ [12].

$\left[\mathrm{Cu}_{2}\left(\mathrm{EtNH}_{2}\right)_{2}\left(\mu-\mathrm{O}_{2} \mathrm{CC}_{3} \mathrm{~F}_{7}\right)_{4}\right](3) \mathrm{C}_{20} \mathrm{H}_{14} \mathrm{Cu}_{2} \mathrm{~F}_{28} \mathrm{~N}_{2} \mathrm{O}_{8}$ [11].

$\left[\mathrm{Cu}_{2}\left(\mathrm{EtNH}_{2}\right)_{2}\left(\mu-\mathrm{O}_{2} \mathrm{CC}_{4} \mathrm{~F}_{9}\right)_{4}\right]$ (4) $\mathrm{C}_{24} \mathrm{H}_{14} \mathrm{Cu}_{2} \mathrm{~F}_{36} \mathrm{~N}_{2} \mathrm{O}_{8}$ (calc./found) \% $\mathrm{Cu}$ 10.0/10.2, C 22.71/23.03, H 1.11/1.53, EI-MS T $=345 \mathrm{~K}(\mathrm{~m} / \mathrm{z}, \mathrm{RI} \%)\left[\mathrm{C}_{2} \mathrm{H}_{7} \mathrm{~N}\right]^{+\cdot}(45,10) ;\left[\mathrm{Cu}_{2}\left(\mathrm{O}_{2} \mathrm{CC}_{4} \mathrm{~F}_{9}\right)\right]^{+}$ $(389,100) ;\left[\mathrm{Cu}_{2}\left(\mathrm{EtNH}_{2}\right)\left(\mathrm{O}_{2} \mathrm{CC}_{4} \mathrm{~F}_{9}\right)\right]^{+}(434,1) ;\left[\mathrm{Cu}_{2}\left(\mathrm{O}_{2} \mathrm{CC}_{4} \mathrm{~F}_{9}\right)_{2}\right]^{+\cdot} \cdot(652,25) ;\left[\mathrm{Cu}_{2}\left(\mathrm{EtNH}_{2}\right)_{2}\right.$ $\left.\left(\mathrm{O}_{2} \mathrm{CC}_{4} \mathrm{~F}_{9}\right)_{3}\right]^{+}(1005,1)$; IR $(\mathrm{KBr}, 3252,3156,3068,2998,2595,2505,1993,1681,1531,1403$, $1348,1210,1162,1135,1056,1043,1024,914,885,815,743,714,656,556,533,452,416$; PE $421,395,350 \mathrm{~cm}^{-1}$ ).

$\left[\mathrm{Cu}_{2}\left(\mathrm{EtNH}_{2}\right)_{2}\left(\mu-\mathrm{O}_{2} \mathrm{CC}_{5} \mathrm{~F}_{11}\right)_{4}\right]$ (5) $\mathrm{C}_{28} \mathrm{H}_{14} \mathrm{Cu}_{2} \mathrm{~F}_{44} \mathrm{~N}_{2} \mathrm{O}_{8}$ (calc. / found) \% Cu 8.7/8.2, C 22.88/22.2, H 0.96/1.10, EI-MS T $=319 \mathrm{~K}(\mathrm{~m} / z, \mathrm{RI} \%)\left[\mathrm{C}_{2} \mathrm{H}_{7} \mathrm{~N}\right]^{+\cdot}(45,28) ;\left[\mathrm{Cu}_{2}\left(\mathrm{O}_{2} \mathrm{CC}_{5} \mathrm{~F}_{11}\right)\right]^{+}$ $(439,94) ;\left[\mathrm{Cu}_{2}\left(\mathrm{EtNH}_{2}\right)\left(\mathrm{O}_{2} \mathrm{CC}_{5} \mathrm{~F}_{11}\right)\right]^{+}(484,2) ;\left[\mathrm{Cu}_{2}\left(\mathrm{O}_{2} \mathrm{CC}_{5} \mathrm{~F}_{11}\right)_{2}\right]^{+\cdot}(752,22) ;\left[\mathrm{Cu}_{2}\left(\mathrm{EtNH}_{2}\right)_{2}\right.$ $\left.\left(\mathrm{O}_{2} \mathrm{CC}_{5} \mathrm{~F}_{11}\right)_{3}\right]^{+}(1155,2)$; IR (KBr, 3245, 3093, 2838, 2743, 2628, 2520, 2046, 1679, 1638, 1545, $1479,1435,1409,1200,1142,1046,996,843,796,726,612,520$; PE 427, 382, $\left.342 \mathrm{~cm}^{-1}\right)$.

$\left[\mathrm{Cu}_{2}\left(\mathrm{EtNH}_{2}\right)_{2}\left(\mu-\mathrm{O}_{2} \mathrm{CC}_{6} \mathrm{~F}_{13}\right)_{4}\right](6) \mathrm{C}_{32} \mathrm{H}_{14} \mathrm{Cu}_{2} \mathrm{~F}_{52} \mathrm{~N}_{2} \mathrm{O}_{8}$ (calc./found) \% Cu 7.6/7.7, C 23.02/22.50, H 0.85/1.13, EI-MS T $=365 \mathrm{~K}(\mathrm{~m} / \mathrm{z}$, RI \% $)\left(\left[\mathrm{C}_{2} \mathrm{H}_{7} \mathrm{~N}\right]^{+\cdot}(45,8) ;\left[\mathrm{Cu}_{2}\left(\mathrm{O}_{2} \mathrm{CC}_{6} \mathrm{~F}_{13}\right)\right]^{+}\right.$ $(489,100) ;\left[\mathrm{Cu}_{2}\left(\mathrm{EtNH}_{2}\right)\left(\mathrm{O}_{2} \mathrm{CC}_{6} \mathrm{~F}_{13}\right)\right]^{+}(534,2) ;\left[\mathrm{Cu}_{2}\left(\mathrm{O}_{2} \mathrm{CC}_{6} \mathrm{~F}_{13}\right)_{2}\right]^{+\cdot}(852,18) ;\left[\mathrm{Cu}_{2}\left(\mathrm{EtNH}_{2}\right)_{2}\right.$ 
$\left.\left(\mathrm{O}_{2} \mathrm{CC}_{6} \mathrm{~F}_{13}\right)_{3}\right]^{+}(1305,1)$; IR (KBr, 3244, 3165, 3068, 2998, 2958, 2738, 2602, 2501, 1982, 1673, 1623, 1527, 1478, 1461, 1404, 1358, 1310, 1290, 1233, 1207, 1150, 1121, 1064, 1049, 976, 961, $930,904,849,805,788,775,744,735,718,705,663,626,591,571,551,529,459,415$; PE 429, $\left.375,343 \mathrm{~cm}^{-1}\right)$.

$\left[\mathrm{Cu}_{2}\left({ }^{\mathrm{i}} \mathrm{PrNH}_{2}\right)_{2}\left(\boldsymbol{\mu}-\mathrm{O}_{2} \mathbf{C C F}_{3}\right)_{4}\right]$ (7) $\mathrm{C}_{14} \mathrm{H}_{18} \mathrm{Cu}_{2} \mathrm{~F}_{12} \mathrm{~N}_{2} \mathrm{O}_{8}$ (calc. /found) \% $\mathrm{Cu} 18.21 / 18.42$, C 24.11/24.91, H 2.60/3.51, EI-MS T = $389 \mathrm{~K}(\mathrm{~m} / z, \mathrm{RI} \%)\left[\mathrm{C}_{3} \mathrm{H}_{9} \mathrm{~N}\right]^{+\cdot}(59,41) ;\left[\mathrm{Cu}\left({ }^{\mathrm{i}} \mathrm{PrNH}_{2}\right)\right.$ $\left.\left(\mathrm{O}_{2} \mathrm{CCF}_{3}\right)\right]^{+}(235,28) ;\left[\mathrm{Cu}_{2}\left({ }^{\mathrm{i}} \mathrm{PrNH}_{2}\right)\left(\mathrm{O}_{2} \mathrm{CCF}_{3}\right)\right]^{+}(298,14) ;\left[\mathrm{Cu}_{2}\left(\mathrm{O}_{2} \mathrm{CCF}_{3}\right)_{2}\right]^{+\cdot}(352,63)$; $\left[\mathrm{Cu}_{2}\left({ }^{\mathrm{i}} \mathrm{PrNH}_{2}\right)_{2}\left(\mathrm{O}_{2} \mathrm{CCF}_{3}\right)_{3}\right]^{+}(583,77)$; IR (ATR, 3082, 2983, 2947, 1666, 1520, 1471, 1431, 1400, 1385, 1190, 1136, 1024, 937, 922, 841, 795, 725, 613, 521, 469, 420, 375, $\left.347 \mathrm{~cm}^{-1}\right)$.

$\left[\mathrm{Cu}_{2}\left({ }^{\mathrm{i}} \mathrm{PrNH}_{2}\right)_{2}\left(\mu-\mathrm{O}_{2} \mathrm{CC}_{2} \mathrm{~F}_{5}\right)_{4}\right](8) \mathrm{C}_{18} \mathrm{H}_{18} \mathrm{Cu}_{2} \mathrm{~F}_{20} \mathrm{~N}_{2} \mathrm{O}_{8}$ (calc./found) \% Cu 14.15/14.84, C 24.09/23.90, H 2.02/2.39, EI-MS T $=404 \mathrm{~K}(\mathrm{~m} / z, \mathrm{RI} \%)\left[\mathrm{C}_{3} \mathrm{H}_{9} \mathrm{~N}\right]^{+\cdot}(59,46) ;\left[\mathrm{Cu}\left({ }^{\mathrm{i}} \mathrm{PrNH}_{2}\right)\right.$ $\left.\left(\mathrm{O}_{2} \mathrm{CC}_{2} \mathrm{~F}_{5}\right)\right]^{+}(285,24) ;\left[\mathrm{Cu}_{2}\left(\mathrm{O}_{2} \mathrm{CC}_{2} \mathrm{~F}_{5}\right)\right]^{+}(289,3) ;\left[\mathrm{Cu}_{2}\left({ }^{\mathrm{i}} \mathrm{PrNH}_{2}\right)\left(\mathrm{O}_{2} \mathrm{CC}_{2} \mathrm{~F}_{5}\right)\right]^{+}(348,16) ;$ $\left[\mathrm{Cu}_{2}\left({ }^{\mathrm{i}} \mathrm{PrNH}_{2}\right)_{2}\left(\mathrm{O}_{2} \mathrm{CC}_{2} \mathrm{~F}_{5}\right)_{3}\right]^{+}(733,72)$; IR (ATR, 3065, 2986, 1675, 1523, 1471, 1403, 1323, $\left.1207,1158,1028,818,732,586,542,471,420,377,360 \mathrm{~cm}^{-1}\right)$.

$\left[\mathrm{Cu}_{2}\left({ }^{\mathrm{i}} \mathrm{PrNH}_{2}\right)_{2}\left(\mu-\mathrm{O}_{2} \mathrm{CC}_{3} \mathrm{~F}_{7}\right)_{4}\right](9) \mathrm{C}_{22} \mathrm{H}_{18} \mathrm{Cu}_{2} \mathrm{~F}_{28} \mathrm{~N}_{2} \mathrm{O}_{8}$ (calc. / found) \% $\mathrm{Cu}$ 11.57/14.09, C 24.08/24.09, H 1.65/2.02, EI-MS T = $372 \mathrm{~K}(\mathrm{~m} / z, \mathrm{RI} \%)\left[\mathrm{C}_{3} \mathrm{H}_{9} \mathrm{~N}\right]^{+\cdot}(59,16) ;\left[\mathrm{Cu}\left({ }^{\mathrm{i}} \mathrm{PrNH}_{2}\right)\right.$ $\left.\left(\mathrm{O}_{2} \mathrm{CC}_{3} \mathrm{~F}_{7}\right)\right]^{+}(334,4) ;\left[\mathrm{Cu}_{2}\left(\mathrm{O}_{2} \mathrm{CC}_{3} \mathrm{~F}_{7}\right)\right]^{+}(339,24) ;\left[\mathrm{Cu}_{2}\left({ }^{\mathrm{i}} \mathrm{PrNH}_{2}\right)\left(\mathrm{O}_{2} \mathrm{CC}_{3} \mathrm{~F}_{7}\right)\right]^{+}(398,5)$; $\left[\mathrm{Cu}_{2}\left(\mathrm{O}_{2} \mathrm{CC}_{3} \mathrm{~F}_{7}\right)_{2}\right]^{+\cdot}(552,4) ;\left[\mathrm{Cu}_{2}\left({ }^{\mathrm{i}} \mathrm{PrNH}_{2}\right)_{2}\left(\mathrm{O}_{2} \mathrm{CC}_{3} \mathrm{~F}_{7}\right)_{3}\right]^{+}(883,24) ; \mathrm{IR}$ (ATR, 3088, 2990, $2955,1683,1630,1592,1522,1473,1406,1340,1275,1207,1165,1119,1086,967,934,818,762$, $\left.745,722,645,603,589,528,475,428,376,351 \mathrm{~cm}^{-1}\right)$.

$\left[\mathrm{Cu}_{2}\left({ }^{\mathbf{i}} \mathrm{PrNH}_{2}\right)_{2}\left(\mu-\mathrm{O}_{2} \mathbf{C C}_{4} \mathrm{~F}_{\mathbf{9}}\right)_{4}\right](\mathbf{1 0}) \mathrm{C}_{26} \mathrm{H}_{18} \mathrm{Cu}_{2} \mathrm{~F}_{36} \mathrm{~N}_{2} \mathrm{O}_{8}$ (calc. /found) \% Cu 9.79/10.32, $\mathrm{C} 24.07 / 23.39, \mathrm{H} 1.40 / 2.23, \mathrm{EI}-\mathrm{MS} \mathrm{T}=401 \mathrm{~K}(\mathrm{~m} / z, \mathrm{RI} \%)\left[\mathrm{C}_{3} \mathrm{H}_{9} \mathrm{~N}\right]^{+\cdot}(59,23) ;\left[\mathrm{Cu}\left({ }^{\mathrm{i}} \mathrm{PrNH}_{2}\right)\right.$ $\left.\left(\mathrm{O}_{2} \mathrm{CC}_{4} \mathrm{~F}_{9}\right)\right]^{+}(385,3) ;\left[\mathrm{Cu}_{2}\left(\mathrm{O}_{2} \mathrm{CC}_{4} \mathrm{~F}_{9}\right)\right]^{+}(389,64) ;\left[\mathrm{Cu}_{2}\left({ }^{\mathrm{i}} \mathrm{PrNH}_{2}\right)\left(\mathrm{O}_{2} \mathrm{CC}_{4} \mathrm{~F}_{9}\right)\right]^{+}(448,5) ;\left[\mathrm{Cu}_{2}\right.$ $\left.\left(\mathrm{O}_{2} \mathrm{CC}_{4} \mathrm{~F}_{9}\right)_{2}\right]^{+\cdot}(652,9)$; $\left[\mathrm{Cu}_{2}\left({ }^{\mathrm{i}} \mathrm{PrNH}_{2}\right)_{2}\left(\mathrm{O}_{2} \mathrm{CC}_{4} \mathrm{~F}_{9}\right)_{3}\right]^{+}(1033,21)$, IR (ATR, 3095, 2987, 1681, $1627,1588,1522,1475,1403,1347,1198,1163,1130,1060,1023,939,916,888,813,743,717$, $\left.657,603,554,535,470,419,376,352 \mathrm{~cm}^{-1}\right)$.

\section{Results and Discussion}

In the case of other simple aliphatic amines, the following reaction:

$2\left[\mathrm{Cu}\left(\mu-\mathrm{O}_{2} \mathrm{CR}_{\mathrm{f}}\right)_{2}\right]+2 \mathrm{RNCO}+2 \mathrm{H}_{2} \mathrm{O} \rightarrow\left[\mathrm{Cu}_{2}\left(\mathrm{RNH}_{2}\right)_{2}\left(\mu-\mathrm{O}_{2} \mathrm{CR}_{\mathrm{f}}\right)_{4}\right]+2 \mathrm{CO}_{2}$ is analogous to those we reported copper compounds containing tert-butylamine [9], as well as ethylamine $\left[\mathrm{Cu}_{2}\left(\mathrm{EtNH}_{2}\right)_{2}\left(\mu-\mathrm{O}_{2} \mathrm{CC}_{2} \mathrm{~F}_{5}\right)_{4}\right](2)$ and $\left[\mathrm{Cu}_{2}\left(\mathrm{EtNH}_{2}\right)_{2}\left(\mu-\mathrm{O}_{2} \mathrm{CC}_{3} \mathrm{~F}_{7}\right)_{4}\right](3)$ complexes [11,12].

The obtained compounds (1-10) were blue, gel-like solids, stable without moisture access for months.

\subsection{Infrared Spectra Analysis}

The results of infrared spectroscopy are given in (Table 1, Figures S1-S10) The strong absorption bands typical of stretching vibrations of the isocyanate group $v_{a s} \mathrm{~N}=\mathrm{C}=\mathrm{O}=$ $2279 \mathrm{~cm}^{-1}$ for ethyl isocyanate and $v_{a s} \mathrm{~N}=\mathrm{C}=\mathrm{O}=2267 \mathrm{~cm}^{-1}$ for isopropyl isocyanate disappeared. Simultaneously, the broad and intense band of the amine N-H stretching and hydrogen bonding vibrations were detected over the range $3060-3100 \mathrm{~cm}^{-1}$ (Table 1). The coordination shifts of this band were calculated in relation to the free amine (for ethylamine $-3360 \mathrm{~cm}^{-1}$, isopropylamine $\left.-3380 \mathrm{~cm}^{-1}\right)$, and they achieved the values approximately $300-270 \mathrm{~cm}^{-1}(\mathbf{1}-\mathbf{6})$ and $320-280 \mathrm{~cm}^{-1}(\mathbf{7}-\mathbf{1 0})$, respectively. The $\mathrm{Cu}-\mathrm{N}$ bond formation and the occurrence of hydrogen bonds NH-F influenced the high value of this shift [28]. The shift of the N-H stretching band towards the lower wavenumber was also observed for other amine complexes of copper as well as palladium and silver [29-31]. Additionally, the signals over the range $1520-1545 \mathrm{~cm}^{-1}$ were detected. They can be assigned to the scissors deformation vibration of the amine group. These bands were shifted down for about 102-80 $\mathrm{cm}^{-1}(\mathbf{1}-\mathbf{6})$ and $98-95 \mathrm{~cm}^{-1}(\mathbf{7 - 1 0})$, which confirms the ethyl- and isopropylamine coordination. The shift of the stretching and deformation bands changed irregularly with the length of the carboxylate carbon chain. 
Table 1. Selected IR absorption bands $\left(\mathrm{cm}^{-1}\right)$ of studied compounds (1-10).

\begin{tabular}{|c|c|c|c|c|c|c|}
\hline \multicolumn{2}{|r|}{ Compound } & \multirow{2}{*}{$\begin{array}{c}\boldsymbol{v} \mathbf{N H}_{\mathbf{2}} \mathbf{b r} \\
3080\end{array}$} & \multirow{2}{*}{$\frac{v_{\text {as }} \mathrm{COO}}{1672}$} & \multirow{2}{*}{$\begin{array}{c}\mathbf{v N H}_{2} \text { scci } \\
1518\end{array}$} & \multirow{2}{*}{$\frac{v_{\mathbf{s}} \mathrm{COO}}{1436}$} & \multirow{2}{*}{$\frac{\Delta v \mathrm{COO}}{236}$} \\
\hline (1) & {$\left[\mathrm{Cu}_{2}\left(\mathrm{EtNH}_{2}\right)_{2}\left(\mu-\mathrm{O}_{2} \mathrm{CCF}_{3}\right)_{4}\right]$} & & & & & \\
\hline (2) & {$\left[\mathrm{Cu}_{2}\left(\mathrm{EtNH}_{2}\right)_{2}\left(\mu-\mathrm{O}_{2} \mathrm{CC}_{2} \mathrm{~F}_{5}\right)_{4}\right]$} & 3080 & 1675 & 1531 & 1413 & 262 \\
\hline (3) & {$\left[\mathrm{Cu}_{2}\left(\mathrm{EtNH}_{2}\right)_{2}\left(\mu-\mathrm{O}_{2} \mathrm{CC}_{3} \mathrm{~F}_{7}\right)_{4}\right]$} & 3060 & 1679 & 1528 & 1405 & 274 \\
\hline (4) & {$\left[\mathrm{Cu}_{2}\left(\mathrm{EtNH}_{2}\right)_{2}\left(\mu-\mathrm{O}_{2} \mathrm{CC}_{4} \mathrm{~F}_{9}\right)_{4}\right]$} & 3070 & 1681 & 1531 & 1403 & 278 \\
\hline (5) & {$\left[\mathrm{Cu}_{2}\left(\mathrm{EtNH}_{2}\right)_{2}\left(\mu-\mathrm{O}_{2} \mathrm{CC}_{5} \mathrm{~F}_{11}\right)_{4}\right]$} & 3090 & 1679 & 1545 & 1409 & 270 \\
\hline (6) & {$\left[\mathrm{Cu}_{2}\left(\mathrm{EtNH}_{2}\right)_{2}\left(\mu-\mathrm{O}_{2} \mathrm{CC}_{6} \mathrm{~F}_{13}\right)_{4}\right]$} & 3070 & 1673 & 1527 & 1404 & 269 \\
\hline (7) & {$\left[\mathrm{Cu}_{2}\left({ }^{\mathrm{i}} \mathrm{PrNH}_{2}\right)_{2}\left(\mu-\mathrm{O}_{2} \mathrm{CCF}_{3}\right)_{4}\right]$} & 3080 & 1666 & 1520 & 1431 & 235 \\
\hline (8) & {$\left[\mathrm{Cu}_{2}\left({ }^{\mathrm{i}} \mathrm{PrNH}_{2}\right)_{2}\left(\mu-\mathrm{O}_{2} \mathrm{CC}_{2} \mathrm{~F}_{5}\right)_{4}\right]$} & 3060 & 1675 & 1523 & 1403 & 272 \\
\hline (9) & {$\left[\mathrm{Cu}_{2}\left({ }^{\mathrm{i}} \mathrm{PrNH}_{2}\right)_{2}\left(\mu-\mathrm{O}_{2} \mathrm{CC}_{3} \mathrm{~F}_{7}\right)_{4}\right]$} & 3090 & 1683 & 1522 & 1406 & 277 \\
\hline (10) & {$\left[\mathrm{Cu}_{2}\left({ }^{\mathrm{i}} \mathrm{PrNH}_{2}\right)_{2}\left(\mu-\mathrm{O}_{2} \mathrm{CC}_{4} \mathrm{~F}_{9}\right)_{4}\right]$} & 3100 & 1681 & 1522 & 1403 & 278 \\
\hline & $\mathrm{EtNH}_{2}$ & 3360 & - & 1625 & - & - \\
\hline & ${ }^{\mathrm{i}} \mathrm{PrNH}_{2}$ & 3380 & - & 1618 & - & - \\
\hline
\end{tabular}

$\Delta v\left(\mathrm{CF}_{3} \mathrm{COONa}\right)=223 \mathrm{~cm}^{-1}, \Delta v\left(\mathrm{C}_{2} \mathrm{~F}_{5} \mathrm{COONa}\right)=268 \mathrm{~cm}^{-1}, \Delta v\left(\mathrm{C}_{\mathrm{n}} \mathrm{F}_{2 \mathrm{n}+1} \mathrm{COONa} ; \mathrm{n}=3-6\right)=272 \mathrm{~cm}^{-1} ;$ br, broad (approximate values).

Asymmetric and symmetric stretching vibrations of the carboxylic group were detected over the ranges: $v_{\mathrm{as}} \mathrm{COO}=1673-1681 \mathrm{~cm}^{-1}$ and $v_{\mathrm{s}} \mathrm{COO}=1403-1436 \mathrm{~cm}^{-1}$ (Table 1 , Figures S1-S10). The calculated $\Delta v=v_{\text {as }} \mathrm{COO}-v_{\mathrm{s}} \mathrm{COO}$ parameter for the $\left[\mathrm{Cu}_{2}\left(\mathrm{EtNH}_{2}\right)_{2}(\mu-\right.$ $\left.\left.\mathrm{O}_{2} \mathrm{CCF}_{3}\right)_{4}\right](\mathbf{1})$ amounted $\Delta v=236 \mathrm{~cm}^{-1}$ and in the case of $\left[\mathrm{Cu}_{2}\left(\mathrm{EtNH}_{2}\right)_{2}\left(\mu-\mathrm{O}_{2} \mathrm{CC}_{\mathrm{n}} \mathrm{F}_{2 \mathrm{n}+1}\right)_{4}\right]$, $\mathrm{n}=2-6(2-6)$ achieved $\Delta v=262-278 \mathrm{~cm}^{-1}$. While for compounds containing an isopropyl group, the calculated amounted $\Delta v=235 \mathrm{~cm}^{-1}$ for the $\left[\mathrm{Cu}_{2}\left({ }^{\mathrm{i}} \mathrm{PrNH}_{2}\right)_{2}\left(\mu-\mathrm{O}_{2} \mathrm{CCF}_{3}\right)_{4}\right](7)$ and reached the value of $\Delta v=272-278 \mathrm{~cm}^{-1}$ for the $\left[\mathrm{Cu}_{2}\left({ }^{\mathrm{i}} \mathrm{PrNH}_{2}\right)_{2}\left(\mu-\mathrm{O}_{2} \mathrm{CC}_{\mathrm{n}} \mathrm{F}_{2 \mathrm{n}+1}\right)_{4}\right], \mathrm{n}=2-4$ $(8-10)$. These values are close to the same parameter found for the appropriate sodium salts $\left(\Delta v\left(\mathrm{CF}_{3} \mathrm{COONa}\right)=223 \mathrm{~cm}^{-1}\right.$ and $\left.\Delta v\left(\mathrm{C}_{\mathrm{n}} \mathrm{F}_{2 \mathrm{n}+1} \mathrm{COONa} ; \mathrm{n}=2-6\right)=268-272 \mathrm{~cm}^{-1}\right)$ which suggests the bridging coordination mode of carboxylates. The analogous relationship was observed in the case previously described $\left[\mathrm{Cu}_{2}\left({ }^{\mathrm{t}} \mathrm{BuNH}_{2}\right)_{2}\left(\mu-\mathrm{O}_{2} \mathrm{CC}_{n} \mathrm{~F}_{2 n+1}\right)_{4}\right]$ complexes with tert-butylamine [9]. The bridging mode of copper(II) carboxylates is in favor of complexes' dimeric units in the solid state [32,33].

Assuming the $\mathrm{C}_{4 \mathrm{v}}$ microsymmetry of the $\mathrm{Cu}$ (II) coordination sphere [9] spectra in the metal-ligand vibrations region $\left(600-100 \mathrm{~cm}^{-1}\right)$ can be described in the following manner: the bands detected over the range $419-429 \mathrm{~cm}^{-1}$ can be assigned to $\mathrm{Cu}-\mathrm{N}$ stretching vibrations and these observed over $375-395 \mathrm{~cm}^{-1}$ and $331-360 \mathrm{~cm}^{-1}$ - to asymmetric and symmetric $\mathrm{CuO}_{4}$ stretching vibrations, respectively [28].

\subsection{Mass Spectra Analysis}

Mass spectra (EI MS) of the studied compounds were measured between 303 and $623 \mathrm{~K}$ (Figures S11-S20) and applied for the molecular mass determination and structural characteristics. Additionally, metallated fragments in the gas phase can be identified, and a preliminary usefulness evaluation of usefulness by vapour deposition techniques can also be considered.

For the $\left[\mathrm{Cu}_{2}\left(\mathrm{EtNH}_{2}\right)_{2}\left(\mu-\mathrm{O}_{2} \mathrm{CR}_{\mathrm{f}}\right)_{4}\right]$ complexes (1-6) (Table 2 and Tables S1-S5), the following fragments, characteristic of ethylamine, were detected: $\left[\mathrm{C}_{2} \mathrm{H}_{7} \mathrm{~N}\right]^{+}(45 \mathrm{~m} / \mathrm{z})$, $\left[\mathrm{C}_{2} \mathrm{H}_{4} \mathrm{~N}\right]^{+}(42 \mathrm{~m} / \mathrm{z}),\left[\mathrm{C}_{2} \mathrm{H}_{3} \mathrm{~N}\right]^{+}(41 \mathrm{~m} / \mathrm{z}),\left[\mathrm{C}_{2} \mathrm{H}_{2} \mathrm{~N}\right]^{+}(40 \mathrm{~m} / \mathrm{z})$. Among these ions, the $\left[\mathrm{C}_{2} \mathrm{H}_{7} \mathrm{~N}\right]^{+}$ fragment exhibits $\mathrm{RI}=69 \%$ for $(\mathbf{1})$ (Table 2 ) at $355 \mathrm{~K}$. Other complexes (2-6) revealed a different behaviour, and their RI achieved only $10-38 \%$ over the temperature range 305-357 K. Additionally, the copper-amine ion $\left[\mathrm{Cu}\left(\mathrm{EtNH}_{2}\right)\right]^{+}(108 \mathrm{~m} / \mathrm{z})$ was observed for the following complexes: (2) (3-4\% RI, up to $357 \mathrm{~K})$, (3) (2-3\% RI, up to $463 \mathrm{~K})$, and (6) $(1-2 \%$ RI, up to $431 \mathrm{~K})$. 
Table 2. Mass spectrometry EI MS data of $\left[\mathrm{Cu}_{2}\left(\mathrm{EtNH}_{2}\right)_{2}\left(\mu-\mathrm{O}_{2} \mathrm{CCF}_{3}\right)_{4}\right](\mathbf{1})$.

\begin{tabular}{|c|c|c|c|c|}
\hline \multirow{2}{*}{ Fragments } & \multirow{2}{*}{$\mathrm{m} / \mathrm{z}$} & \multicolumn{3}{|c|}{$\mathrm{RI}[\%]$} \\
\hline & & $305 \mathrm{~K}$ & $355 \mathrm{~K}$ & $600 \mathrm{~K}$ \\
\hline$\left[\mathrm{C}_{2} \mathrm{H}_{2} \mathrm{~N}\right]^{+}$ & 40 & 7 & 6 & - \\
\hline$\left[\mathrm{C}_{2} \mathrm{H}_{3} \mathrm{~N}\right]^{+}$ & 41 & 11 & 8 & - \\
\hline$\left[\mathrm{C}_{2} \mathrm{H}_{4} \mathrm{~N}\right]^{+}$ & 42 & 15 & 13 & - \\
\hline$\left[\mathrm{CO}_{2}\right]^{+}$ & 44 & 35 & 33 & 100 \\
\hline$\left[\mathrm{C}_{2} \mathrm{H}_{7} \mathrm{~N}\right]^{+} \cdot /[\mathrm{COOH}]^{+}$ & 45 & 45 & 69 & 3 \\
\hline$\left[\mathrm{CF}_{2}\right]^{+}$ & 50 & 20 & 20 & 11 \\
\hline$\left[\mathrm{CF}_{3}\right]^{+}$ & 69 & 93 & 100 & 61 \\
\hline$\left[\mathrm{CF}_{3} \mathrm{CO}\right]^{+}$ & 97 & 9 & 9 & 6 \\
\hline$[\mathrm{Cu}]^{+}$ & 63 & 40 & 26 & 1 \\
\hline$\left[\mathrm{Cu}_{2}\right]^{+\cdot}$ & 126 & 6 & 7 & - \\
\hline$\left[\mathrm{Cu}_{2} \mathrm{~F}\right]^{+}$ & 145 & 25 & 24 & 2 \\
\hline$\left[\mathrm{Cu}\left(\mathrm{EtNH}_{2}\right)\left(\mathrm{O}_{2} \mathrm{CCF}_{3}\right)\right]^{+}$ & 221 & 11 & 3 & - \\
\hline$\left[\mathrm{Cu}_{2}\left(\mathrm{O}_{2} \mathrm{CCF}_{3}\right)\right]^{+}$ & 239 & 100 & 98 & 6 \\
\hline$\left[\mathrm{Cu}_{2}\left(\mathrm{EtNH}_{2}\right)\left(\mathrm{O}_{2} \mathrm{CCF}_{3}\right)\right]^{+}$ & 284 & 5 & 2 & - \\
\hline$\left[\mathrm{Cu}_{2}\left(\mathrm{O}_{2} \mathrm{CCF}_{3}\right)_{2}\right]^{+\cdot}$ & 352 & 66 & 61 & 4 \\
\hline$\left[\mathrm{Cu}_{2}\left(\mathrm{O}_{2} \mathrm{CCF}_{3}\right)_{3}\right]^{+}$ & 465 & 7 & 1 & - \\
\hline$\left[\mathrm{Cu}_{2}\left(\mathrm{EtNH}_{2}\right)\left(\mathrm{O}_{2} \mathrm{CCF}_{3}\right)_{3}\right]^{+}$ & 510 & 11 & 3 & - \\
\hline$\left[\mathrm{Cu}_{2}\left(\mathrm{EtNH}_{2}\right)_{2}\left(\mathrm{O}_{2} \mathrm{CCF}_{3}\right)_{3}\right]^{+}$ & 555 & 3 & - & - \\
\hline$\left[\mathrm{Cu}_{3}\left(\mathrm{O}_{2} \mathrm{CCF}_{3}\right)_{5}\right]^{+}$ & 756 & 2 & - & - \\
\hline
\end{tabular}

Similar ions were observed for the $\left[\mathrm{Cu}_{2}\left({ }^{\mathrm{i}} \mathrm{PrNH}_{2}\right)_{2}\left(\mu-\mathrm{O}_{2} \mathrm{CR}_{\mathrm{f}}\right)_{4}\right]$ complexes (7-10) (Table 3 and Tables S6-S8), a molecular ion characteristic for isopropylamine was recorded $\left[\mathrm{C}_{3} \mathrm{H}_{9} \mathrm{~N}\right]^{+}(59 \mathrm{~m} / \mathrm{z})$ and achieved the highest intensity $\mathrm{RI}=46 \%$ for $(8)$ at $404 \mathrm{~K}$, for other compounds intensity of this ion were in the range of $16-41 \%$ for $(7,9,10)$ at $372-389 \mathrm{~K}$. The highest intensity of a metallated fragment with isopropylamine molecule $\left[\mathrm{Cu}\left({ }^{\mathrm{i}} \mathrm{PrNH}_{2}\right)\right]^{+}$ $(122 \mathrm{~m} / \mathrm{z})$ were observed for $(8) \mathrm{RI}=53 \%$ at $404 \mathrm{~K}$, while for other compounds (7) $\mathrm{RI}=40 \%$ at $389 \mathrm{~K}$ and $(9) \mathrm{RI}=25 \%$ at $372 \mathrm{~K}$.

Table 3. Mass spectrometry EI MS data of $\left[\mathrm{Cu}_{2}\left({ }^{\mathrm{i}} \mathrm{PrNH}_{2}\right)_{2}\left(\mu-\mathrm{O}_{2} \mathrm{CCF}_{3}\right)_{4}\right](7)$.

\begin{tabular}{|c|c|c|c|c|}
\hline \multirow{2}{*}{ Fragments } & \multirow{2}{*}{$m / z$} & \multicolumn{3}{|c|}{ RI[\%] } \\
\hline & & $368 \mathrm{~K}$ & $389 \mathrm{~K}$ & $548 \mathrm{~K}$ \\
\hline$\left[\mathrm{C}_{2} \mathrm{H}_{2} \mathrm{~N}\right]^{+}$ & 40 & 1 & 50 & 3 \\
\hline$\left[\mathrm{C}_{2} \mathrm{H}_{3} \mathrm{~N}\right]^{+}$ & 41 & - & 1 & 8 \\
\hline$\left[\mathrm{C}_{2} \mathrm{H}_{4} \mathrm{~N}\right]^{+}$ & 42 & 1 & 1 & 6 \\
\hline$\left[\mathrm{C}_{3} \mathrm{H}_{7}\right]^{+}$ & 43 & 42 & 80 & 2 \\
\hline$\left[\mathrm{CO}_{2}\right]^{+}$ & 44 & 100 & 6 & 4 \\
\hline$\left[\mathrm{C}_{2} \mathrm{H}_{7} \mathrm{~N}\right]^{+} /[\mathrm{COOH}]^{+\cdot}$ & 45 & 40 & 37 & 40 \\
\hline$\left[\mathrm{CF}_{2}\right]^{+}$ & 50 & 8 & 67 & 52 \\
\hline$\left[\mathrm{C}_{3} \mathrm{H}_{7} \mathrm{~N}\right]^{+}$ & 57 & 18 & 19 & - \\
\hline$\left[\mathrm{C}_{3} \mathrm{H}_{8} \mathrm{~N}\right]^{+}$ & 58 & 69 & 1 & - \\
\hline$\left[\mathrm{C}_{3} \mathrm{H}_{9} \mathrm{~N}\right]^{+\cdot}$ & 59 & 19 & 41 & 2 \\
\hline$\left[\mathrm{CF}_{3}\right]^{+}$ & 69 & 44 & 2 & 1 \\
\hline$\left[\mathrm{CF}_{3} \mathrm{CO}\right]^{+}$ & 97 & 4 & 55 & 32 \\
\hline$[\mathrm{Cu}]^{+}$ & 63 & - & 20 & 44 \\
\hline$\left[\mathrm{Cu}\left({ }^{\mathrm{i}} \operatorname{PrNH} \mathrm{NH}_{2}\right)\right]^{+}$ & 122 & 2 & 40 & - \\
\hline$\left[\mathrm{Cu}_{2}\right]^{+\cdot}$ & 126 & - & 8 & 11 \\
\hline$\left[\mathrm{Cu}_{2} \mathrm{~F}\right]^{+}$ & 145 & - & 29 & 39 \\
\hline$\left[\mathrm{Cu}\left({ }^{\mathrm{i}} \operatorname{PrNH}_{2}\right)\left(\mathrm{O}_{2} \mathrm{CCF}_{3}\right)\right]^{+}$ & 235 & 1 & 28 & 2 \\
\hline$\left[\mathrm{Cu}_{2}\left(\mathrm{O}_{2} \mathrm{CCF}_{3}\right)\right]^{+}$ & 239 & - & - & 99 \\
\hline$\left[\mathrm{Cu}\left({ }^{\mathrm{i}} \mathrm{PrNH}_{2}\right)_{2}\left(\mathrm{O}_{2} \mathrm{CCF}_{3}\right)\right]^{+}$ & 294 & 1 & 22 & - \\
\hline$\left[\mathrm{Cu}_{2}\left({ }^{\mathrm{i}} \mathrm{PrNH}_{2}\right)\left(\mathrm{O}_{2} \mathrm{CCF}_{3}\right)\right]^{+}$ & 298 & 1 & 14 & - \\
\hline$\left[\mathrm{Cu}_{2}\left(\mathrm{O}_{2} \mathrm{CCF}_{3}\right)_{2}\right]^{+\cdot}$ & 352 & - & 63 & 45 \\
\hline$\left[\mathrm{Cu}_{2}\left(\mathrm{O}_{2} \mathrm{CCF}_{3}\right)_{3}\right]^{+\mathrm{a})}$ & 465 & - & - & - \\
\hline$\left[\mathrm{Cu}_{2}\left({ }^{\mathrm{i}} \mathrm{PrNH}_{2}\right)\left(\mathrm{O}_{2} \mathrm{CCF}_{3}\right)_{3}\right]^{+}$ & 524 & - & 12 & - \\
\hline$\left[\mathrm{Cu}_{2}\left({ }^{\mathrm{i}} \mathrm{PrNH}_{2}\right)_{2}\left(\mathrm{O}_{2} \mathrm{CCF}_{3}\right)_{3}\right]^{+}$ & 583 & 5 & 77 & - \\
\hline
\end{tabular}

a) The $\left[\mathrm{Cu}_{2}\left(\mathrm{O}_{2} \mathrm{CCF}_{3}\right)_{3}\right]^{+}{ }_{2}$ ion $(465 \mathrm{~m} / \mathrm{z})$ was detected but not at the temperatures selected for Table 3 . 
The $\left[\mathrm{Cu}_{2}\left(\mathrm{O}_{2} \mathrm{CR}_{\mathrm{f}}\right)\right]^{+}$and $\left[\mathrm{Cu}_{2}\left(\mathrm{O}_{2} \mathrm{CR}_{\mathrm{f}}\right)_{2}\right]^{+}$dicopper carboxylate ions were noticed in the gas phase of all the studied complexes (Figures 1 and 2), which confirms the dimeric structure of the compounds (1-10). For the complexes with ethylamine, the $\left[\mathrm{Cu}_{2}\left(\mathrm{O}_{2} \mathrm{CR}_{\mathrm{f}}\right)\right]^{+}$ ion achieved the highest intensity (up to $100 \%$ ) over the range 305-425 K (Tables 2 and S1-S5). Interestingly, for the complexes (2) and (3), the high intensity (100\% RI) of the $\left[\mathrm{Cu}_{2}\left(\mathrm{O}_{2} \mathrm{CR}_{\mathrm{f}}\right)\right]^{+}$ion was maintained up to $542 \mathrm{~K}$ (Tables $\mathrm{S} 1$ and S2). For compounds with isopropylamine, the $\left[\mathrm{Cu}_{2}\left(\mathrm{O}_{2} \mathrm{CR}_{\mathrm{f}}\right)\right]^{+}$ion reaches a maximum intensity of $64 \% \mathrm{RI}$ at $401 \mathrm{~K}$ for compound (10). The $\left[\mathrm{Cu}_{2}\left(\mathrm{O}_{2} \mathrm{CR}_{\mathrm{f}}\right)_{2}\right]^{+\cdot}$ fragment generally accompanies the $\left[\mathrm{Cu}_{2}\left(\mathrm{O}_{2} \mathrm{CR}_{\mathrm{f}}\right)\right]^{+}$ ion, but its intensity is usually lower. The fragmentation of the long-chain carboxylates influences the amount and intensity of the fluorocarbon species, e.g., $\left[\mathrm{C}_{2} \mathrm{~F}_{5}\right]^{+},\left[\mathrm{C}_{4} \mathrm{~F}_{7}\right]^{+}$. The formation of the $\left[\mathrm{C}_{3} \mathrm{~F}_{5}\right]^{+}$ion (RI to $100 \%$ ), which is the analogue of the allyl cation, was observed for the compounds (3-6 and 9-10). Moreover, the less complicated metallated fragments: $\left[\mathrm{Cu}_{2} \mathrm{~F}\right]^{+}(145 \mathrm{~m} / \mathrm{z}),\left[\mathrm{Cu}_{2}\right]^{+\cdot}(126 \mathrm{~m} / \mathrm{z})$, and $[\mathrm{Cu}]^{+}(63 \mathrm{~m} / \mathrm{z})$ were detected as the fragmentation terminal products. This fact may indicate the sensitivity of the compounds to the electron beam and the formation of a mixture of copper and copper(I) fluoride. The intensity of the $\left[\mathrm{Cu}_{2} \mathrm{~F}\right]^{+}$ion was relatively high comparison to the analogous complexes with tert-butylamine [9]. The $\left[\mathrm{Cu}_{3}\left(\mathrm{O}_{2} \mathrm{CR}_{\mathrm{f}}\right)_{5}\right]^{+}$ion was also detected for some studied carboxylate compounds with ethylamine $(\mathbf{1}, \mathbf{4}, \mathbf{5})$ and isopropylamine $(\mathbf{9}, \mathbf{1 0})$.

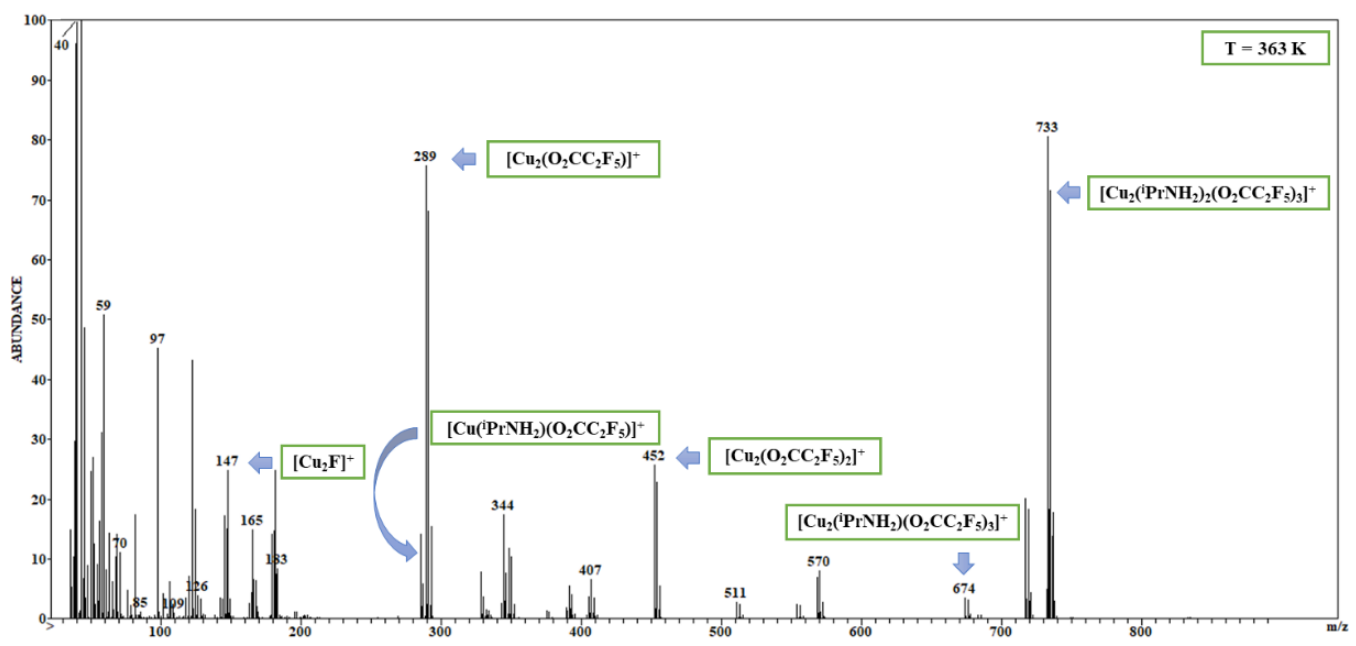

Figure 1. EI MS spectrum of $\left[\mathrm{Cu}_{2}\left({ }^{\mathrm{i}} \mathrm{PrNH}_{2}\right)_{2}\left(\mu-\mathrm{O}_{2} \mathrm{CC}_{2} \mathrm{~F}_{5}\right)_{4}\right](8), \mathrm{T}=363 \mathrm{~K}$.

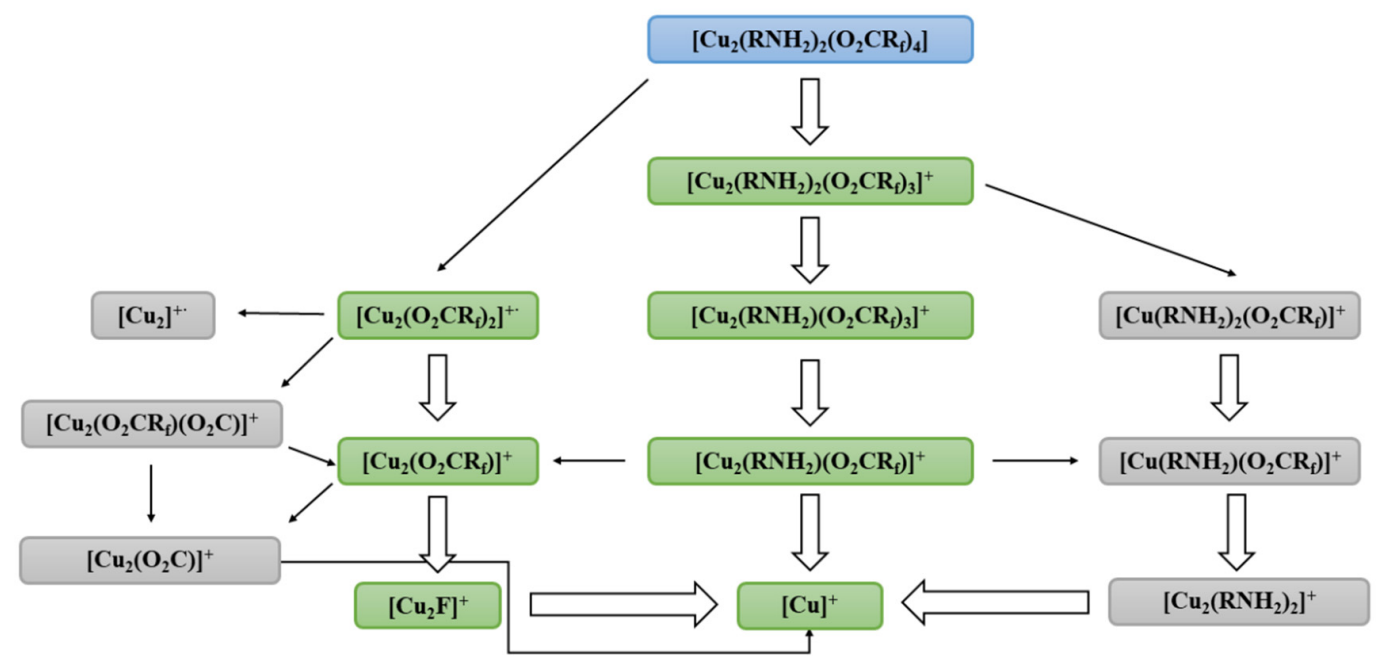

Figure 2. Fragmentation scheme for metallated fragments of $\left[\mathrm{Cu}_{2}\left(\mathrm{RNH}_{2}\right)_{2}\left(\mu-\mathrm{O}_{2} \mathrm{CR}_{\mathrm{f}}\right)_{4}\right]$ (marked green-observed for all compounds (1-10); marked grey-observed for some complexes). 
The detection of the metallated fragments containing both ligands, i.e., $\left[\mathrm{Cu}\left(\mathrm{RNH}_{2}\right)\right.$ $\left.\left(\mathrm{O}_{2} \mathrm{CR}_{\mathrm{f}}\right)\right]^{+},\left[\mathrm{Cu}\left(\mathrm{RNH}_{2}\right)_{2}\left(\mathrm{O}_{2} \mathrm{CR}_{\mathrm{f}}\right)\right]^{+},\left[\mathrm{Cu}_{2}\left(\mathrm{RNH}_{2}\right)\left(\mathrm{O}_{2} \mathrm{CR}_{\mathrm{f}}\right)\right]^{+},\left[\mathrm{Cu}_{2}\left(\mathrm{RNH}_{2}\right)\left(\mathrm{O}_{2} \mathrm{CR}_{\mathrm{f}}\right)_{3}\right]^{+}$and the pseudomolecular $\left[\mathrm{Cu}_{2}\left(\mathrm{RNH}_{2}\right)_{2}\left(\mathrm{O}_{2} \mathrm{CR}_{\mathrm{f}}\right)_{3}\right]^{+}$ion (simulations of isotopic patterns are shown in the Figures S11-S20) was the most important (Figures 1 and 2). The latter was formed by one carboxylate ligand detaching. It was also observed for the complex (6) whose molecular mass is the highest. The majority of metallated fragments were dinuclear, but in the case of the complexes (1), (7)-(10), monocopper fragments containing both ligands were detected as well (Table 2 and Tables S6-S8). In the mass spectra of the tested compounds, the following fragments which contain $\mathrm{Cu}(\mathrm{I})$ ions appear: $\left[\mathrm{Cu}\left(\mathrm{RNH}_{2}\right)\right]^{+},\left[\mathrm{Cu}_{2}\left(\mathrm{O}_{2} \mathrm{CR}_{\mathrm{f}}\right)\right]^{+}$, $\left[\mathrm{Cu}_{2}\left(\mathrm{O}_{2} \mathrm{CR}_{\mathrm{f}}\right)_{2}\right]^{+}$, and $\left[\mathrm{Cu}_{2}\left(\mathrm{RNH}_{2}\right)\left(\mathrm{O}_{2} \mathrm{CR}_{\mathrm{f}}\right)\right]^{+}$. It suggests that the copper(II) reduction can occur during the thermolysis. When the $\left[\mathrm{Cu}_{2}\left({ }^{\mathrm{t}} \mathrm{BuNH}\right)_{2}\left(\mu-\mathrm{O}_{2} \mathrm{CR}_{\mathrm{f}}\right)_{4}\right]$ complexes were used as $\mathrm{Cu} C V D$ precursors, this process resulted in metallic copper formation [10]. Generally, the metallated fragments group achieved the highest intensity (at least the level of a few percent) over the temperature range 305-600 K and 340-548 K for complexes with ethyland isopropylamine, respectively. The complexes (1), (2), and (5) showed the lowest temperature of the metallated fragments generation, and they seemed to be promising for CVD purposes.

Summarising, the types of the observed fragments in the case of ethyl- and isopropylamine complexes were almost the same as those of the tert-butylamine derivatives. Additionally, the $\left[\mathrm{Cu}\left(\mathrm{O}_{2} \mathrm{C}\right)\right]^{+}$ion $(\mathbf{2}, \mathbf{3}, \mathbf{6}, \mathbf{8})$ and the $\left[\mathrm{Cu}\left(\mathrm{RNH}_{2}\right)_{2}\left(\mathrm{O}_{2} \mathrm{CCF}_{3}\right)\right]^{+}$fragment $(\mathbf{1}$, 7-10) were detected. The temperatures at which the $\left[\mathrm{Cu}_{2}\left(\mathrm{EtNH}_{2}\right)_{2}\left(\mathrm{O}_{2} \mathrm{CR}_{\mathrm{f}}\right)_{3}\right]^{+}$pseudomolecular ions achieved the highest intensity, were generally lower (305-357 K) for the $\left[\mathrm{Cu}_{2}\left(\mathrm{EtNH}_{2}\right)_{2}\left(\mu-\mathrm{O}_{2} \mathrm{CR}_{\mathrm{f}}\right)_{4}\right]$ complexes than in the case of the $\left[\mathrm{Cu}_{2}\left({ }^{\mathrm{i}} \mathrm{PrNH}_{2}\right)_{2}\left(\mu-\mathrm{O}_{2} \mathrm{CR}_{\mathrm{f}}\right)_{4}\right]$ $(389-404 \mathrm{~K})$ and $\left[\mathrm{Cu}_{2}\left({ }^{\mathrm{t}} \mathrm{BuNH}_{2}\right)_{2}\left(\mu-\mathrm{O}_{2} \mathrm{CR}_{\mathrm{f}}\right)_{4}\right]$ analogues $(369-465 \mathrm{~K})$. It means that the complexes with ethylamine show the highest volatility among the tested compounds. A similar dependence was observed for the $\left[\mathrm{Cu}_{2}\left(\mathrm{O}_{2} \mathrm{CR}_{\mathrm{f}}\right)\right]^{+}$ions. The highest intensities (up to 100\%) were achieved over the temperature range 305-425 $\mathrm{K}\left(\mathrm{EtNH}_{2}\right)$ in relation to $401-548 \mathrm{~K}$ $\left({ }^{\mathrm{i}} \mathrm{PrNH}_{2}\right)$ and $505-573 \mathrm{~K}\left({ }^{\mathrm{t}} \mathrm{BuNH}_{2}\right)$. Seemingly, these data concerning temperatures may appear as promising for the chemical vapour deposition purposes. Additionally, the [Cu] ${ }^{+}$ high intensity (40\% RI), especially observed simultaneously with the pseudomolecular ion detection, suggests that, from among the studied complexes with $\mathrm{EtNH}_{2},{ }^{\mathrm{i}} \mathrm{PrNH}_{2}$, and ${ }^{t} \mathrm{BuNH}_{2}$, to the electron, is $\left[\mathrm{Cu}_{2}\left(\mathrm{EtNH}_{2}\right)_{2}\left(\mu-\mathrm{O}_{2} \mathrm{CCF}_{3}\right)_{4}\right]$ is the compound most sensitive to the electrons (1).

\subsection{Results of Thermal Analysis}

The thermal analysis of the complexes (1-4) and (7-10) indicates that the slow weight loss occurs from the beginning of heating of the complex (Figures S21 and S23-S28). A complicated process is observed at higher temperatures. Analysis of the DTA curve for these compounds indicates the endothermic effects connected with thermal decomposition.

The temperature of the decomposition process onset changed over the range 388-410 K and 308-355 $\mathrm{K}$ for complexes containing ethyl or isopropyl group, respectively. The temperature of the final product formation varied from $505 \mathrm{~K}$ to $532 \mathrm{~K}(\mathbf{1}),(\mathbf{3}),(4)$, and $478 \mathrm{~K}$ to $548 \mathrm{~K}$ (7-10). The lowest $\mathrm{T}_{\mathrm{m}}(466 \mathrm{~K}$ and 463-464 K) was observed for the compound (3), (9), and (10) containing chain $\mathrm{R}_{\mathrm{f}}=\mathrm{C}_{3} \mathrm{~F}_{7}, \mathrm{C}_{4} \mathrm{~F}_{9}$ and the highest value (486 $\mathrm{K}$ and $474 \mathrm{~K}$ ) for (1) and (7) including group $\mathrm{CF}_{3}$. The mass of the residues after the thermal analysis for compounds (1) and (7) reveals that the decomposition product of the compounds with $\mathrm{EtNH}_{2}$ is metallic copper, while for compounds with ${ }^{\mathrm{i}} \mathrm{PrNH}_{2}$, it is copper(II) oxide (Table 4). The formation of these substances is also confirmed by the color of the residue, red-orange and black, respectively. In the case of the complexes (3), (4), (8), and (9), the mass of the final decomposition products was lower than the value calculated for pure copper or copper(II) oxide (Table 4), which suggests that the copper transfer to the gas phase occurred under the atmospheric pressure, which seemed promising for the CVD and FEBID application. The higher residue mass with regard to its theoretical value for the compound (10) $\left(R_{f}=C_{6} F_{13}\right)$ may indicate carbon contamination during thermal decomposition. 
Table 4. Thermal analysis data.

\begin{tabular}{|c|c|c|c|c|c|}
\hline \multirow{2}{*}{ Complex } & \multicolumn{3}{|c|}{ Temperature (K) } & \multicolumn{2}{|c|}{ Residue (\%) } \\
\hline & $T_{i}$ & $\mathrm{~T}_{\mathrm{m}}$ & $T_{f}$ & Found & Calc. \\
\hline$\left[\mathrm{Cu}_{2}\left(\mathrm{EtNH}_{2}\right)_{2}\left(\mu-\mathrm{O}_{2} \mathrm{CCF}_{3}\right)_{4}\right](1)$ & 410 & 486 & 532 & 18.17 & $18.99(\mathrm{Cu})$ \\
\hline$\left[\mathrm{Cu}_{2}\left(\mathrm{EtNH}_{2}\right)_{2}\left(\mu-\mathrm{O}_{2} \mathrm{CC}_{3} \mathrm{~F}_{7}\right)_{4}\right]$ & 395 & 466 & 505 & 6.03 & $11.88(\mathrm{Cu})$ \\
\hline$\left[\mathrm{Cu}_{2}\left(\mathrm{EtNH}_{2}\right)_{2}\left(\mu-\mathrm{O}_{2} \mathrm{CC}_{4} \mathrm{~F}_{9}\right)_{4}\right](4)$ & 388 & 476 & 520 & 6.97 & $10.01(\mathrm{Cu})$ \\
\hline$\left[\mathrm{Cu}_{2}\left({ }^{\mathrm{i}} \mathrm{PrNH}_{2}\right)_{2}\left(\mu-\mathrm{O}_{2} \mathrm{CCF}_{3}\right)_{4}\right](7)$ & 312 & 474 & 528 & 22.9 & $22.8(\mathrm{CuO})$ \\
\hline$\left[\mathrm{Cu}_{2}\left({ }^{\mathrm{i}} \mathrm{PrNH}_{2}\right)_{2}\left(\mu-\mathrm{O}_{2} \mathrm{CC}_{2} \mathrm{~F}_{5}\right)_{4}\right](8)$ & 323 & 449 & 478 & 4.72 & $17.7(\mathrm{CuO})$ \\
\hline$\left[\mathrm{Cu}_{2}\left({ }^{\mathrm{i}} \mathrm{PrNH}_{2}\right)_{2}\left(\mu-\mathrm{O}_{2} \mathrm{CC}_{3} \mathrm{~F}_{7}\right)_{4}\right](9)$ & 308 & 464 & 548 & 7.2 & $14.5(\mathrm{CuO})$ \\
\hline$\left[\mathrm{Cu}_{2}\left({ }^{\mathrm{i}} \mathrm{PrNH}_{2}\right)_{2}\left(\mu-\mathrm{O}_{2} \mathrm{CC}_{4} \mathrm{~F}_{9}\right)_{4}\right](10)$ & 355 & 463 & 510 & 14.4 & $12.2(\mathrm{CuO})$ \\
\hline
\end{tabular}

$T_{i}$, initial temperature; $T_{m}$, maximum temperature; $T_{f}$, final temperature.

In the case of $\left[\mathrm{Cu}_{2}\left(\mathrm{EtNH}_{2}\right)_{2}\left(\mu-\mathrm{O}_{2} \mathrm{CR}_{\mathrm{f}}\right)_{4}\right]$ complexes, the onset temperatures achieved higher values than those for the tert-butylamine analogues. However, for the $\left[\mathrm{Cu}_{2}\left({ }^{\mathrm{i} P r N H}\right)_{2}\right.$ $\left.\left(\mu-\mathrm{O}_{2} \mathrm{CR}_{\mathrm{f}}\right)_{4}\right]$ complexes, the initial temperatures of the decomposition process were similar to the temperatures observed for the compounds containing the tert-butylamine group. On the contrary, the observed final decomposition temperatures were lower for the compounds containing ethylamine and also the isopropylamine group. It means that the thermal decomposition ranges for the $\left[\mathrm{Cu}_{2}\left(\mathrm{RNH}_{2}\right)_{2}\left(\mu-\mathrm{O}_{2} \mathrm{CR}_{\mathrm{f}}\right)_{4}\right]$ complexes discussed here are narrower than those for previously described $\left[\mathrm{Cu}_{2}\left({ }^{\mathrm{t}} \mathrm{BuNH}_{2}\right)_{2}\left(\mu-\mathrm{O}_{2} \mathrm{CR}_{\mathrm{f}}\right)_{4}\right]$ compounds. Interestingly, in the case of complexes with ${ }^{\mathrm{t}} \mathrm{BuNH}_{2},\left[\mathrm{Cu}_{2}\left({ }^{\mathrm{t}} \mathrm{BuNH}\right)_{2}\left(\mu-\mathrm{O}_{2} \mathrm{CCF}_{3}\right)_{4}\right]$ was the most volatile, while for ${ }^{\mathrm{i}} \mathrm{PrNH}_{2}$ and $\mathrm{EtNH}_{2}$, it was observed that compounds with trifluoroacetate have the lowest volatility [9].

Due to the complexity of the process of thermal decomposition of the compounds, we decided to investigate it in more detail for the complex (1) by examining gas phase composition during thermal analysis by infrared spectroscopy (TGA/IR). The spectra analysis showed the characteristic absorption bands for coordinated ethylamine $\left(\nu \mathrm{CH}=2990 \mathrm{~cm}^{-1}\right.$, $\left.\delta \mathrm{NH}_{2}=1524 \mathrm{~cm}^{-1}\right)$ and carboxylate ligands $\left(v_{\mathrm{as}} \mathrm{COO}=1701 \mathrm{~cm}^{-1}, v_{\mathrm{s}} \mathrm{COO}=1440 \mathrm{~cm}^{-1}\right)$. These results suggested that from 413 to $436 \mathrm{~K}$, the complex (1) undergoes evaporation. The $2361 \mathrm{~cm}^{-1}$ band, characteristics of $\mathrm{CO}_{2}$ [34], was detected over the whole studied temperature range (413-501 K), but between 446 and $478 \mathrm{~K}$, its intensity decreased rapidly (Figure S22). The bands typical for fluorinated species $\left(\vee C F=1199 \mathrm{~cm}^{-1}\right.$, $1156 \mathrm{~cm}^{-1}$ ) were observed throughout the temperature range. The typical bands for $\mathrm{H}_{2} \mathrm{O}$ $\left(\nu \mathrm{OH}=4000-3500 \mathrm{~cm}^{-1}, \delta \mathrm{OH}=1800-1300 \mathrm{~cm}^{-1}\right)$ [35] were registered over the 446-501 K. The free amine [36] was detected over $413-478 \mathrm{~K}$. The observed organic molecule bands indicate the partial compound decomposition in the gas phase (Figure 3).

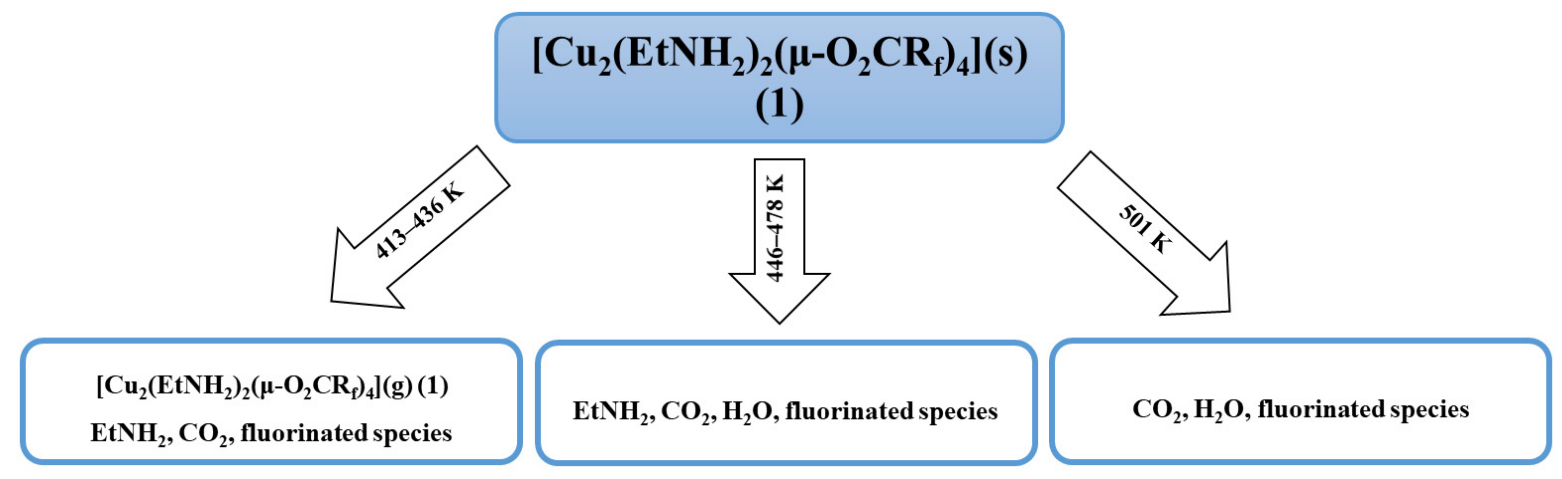

Figure 3. The thermal decomposition scheme for $\left[\mathrm{Cu}_{2}\left(\mathrm{EtNH}_{2}\right)_{2}\left(\mu-\mathrm{O}_{2} \mathrm{CCF}_{3}\right)_{4}\right](\mathbf{1})$ proposed based on TG-IR results.

The TGA/IR results confirm that the thermal decomposition of the compound (1) is a complicated process. Additionally, it has been shown that the complex (1) enters the gas 
phase in the initial heating phase in a narrow temperature range and is accompanied by its decomposition.

\subsection{Temperature Variable Infrared Spectroscopy}

The following selected compounds $\left[\mathrm{Cu}_{2}\left(\mathrm{EtNH}_{2}\right)_{2}\left(\mu-\mathrm{O}_{2} \mathrm{CCF}_{3}\right)_{4}\right](\mathbf{1}),\left[\mathrm{Cu}_{2}\left(\mathrm{EtNH}_{2}\right)_{2}(\mu-\right.$ $\left.\left.\mathrm{O}_{2} \mathrm{CC}_{2} \mathrm{~F}_{5}\right)_{4}\right](2),\left[\mathrm{Cu}_{2}\left(\mathrm{EtNH}_{2}\right)_{2}\left(\mu-\mathrm{O}_{2} \mathrm{CC}_{4} \mathrm{~F}_{9}\right)_{4}\right](4),\left[\mathrm{Cu}_{2}\left({ }^{\mathrm{i}} \mathrm{PrNH}_{2}\right)_{2}\left(\mu-\mathrm{O}_{2} \mathrm{CCF}_{3}\right)_{4}\right](7)$, and $\left[\mathrm{Cu}_{2}\left({ }^{\mathrm{i}} \mathrm{PrNH}_{2}\right)_{2}\left(\mu-\mathrm{O}_{2} \mathrm{CC}_{2} \mathrm{~F}_{5}\right)_{4}\right]$ (8) were studied by temperature variable infrared spectroscopy (VT IR) over the temperature range 303-753 K.

In the case of the $\left[\mathrm{Cu}_{2}\left(\mathrm{EtNH}_{2}\right)_{2}\left(\mu-\mathrm{O}_{2} \mathrm{CCF}_{3}\right)_{4}\right](\mathbf{1})$ four bands $\left(1801 \mathrm{~cm}^{-1}, 1759 \mathrm{~cm}^{-1}\right.$, $1709 \mathrm{~cm}^{-1}$, and $1682 \mathrm{~cm}^{-1}$ ) within the range characteristic of $\mathrm{C}=\mathrm{O}$ stretching vibrations were observed in the temperature between 433 and $533 \mathrm{~K}$. The first is typical of gas-phase ethyl trifluoroacetate, which seems to be the decomposition product [37] The carboxylic acid formation was also considered, but in the spectrum of $\mathrm{CF}_{3} \mathrm{COOH}$ acid in the gas phase, the band $\nu \mathrm{C}=\mathrm{O}$ band appears at $1826 \mathrm{~cm}^{-1}$ and $1788 \mathrm{~cm}^{-1}$ for the monomeric and the dimeric form, respectively [38-40]. Due to the existence of a band coordination shift relative to $v_{\mathrm{as}} \mathrm{COO}$ for the free carboxylic acid, other bands in this area can be attributed to asymmetric vibrations of the coordinated COO group (Figure 4). Therefore, the lowest band $\left(1682 \mathrm{~cm}^{-1}\right)$ can be assigned to the $v_{\mathrm{as}} \mathrm{COO}$ vibrations in the copper carboxylate $\left[\mathrm{Cu}_{2}\left(\mu-\mathrm{O}_{2} \mathrm{CCF}_{3}\right)_{4}\right]$, as evidenced by the gas-phase spectrum measured for copper(II) pentafluoropropionate (Figure S29). In the solid-phase spectra, the $\mathrm{v}_{\mathrm{as}} \mathrm{COO}$ band are shifted towards higher values for the amine-containing compounds when compared to the copper carboxylate $\left(1647 \mathrm{~cm}^{-1}\right.$ $\rightarrow 1672 \mathrm{~cm}^{-1}$; Figure S30 and Figure 5). Taking this fact into account, the band at $1709 \mathrm{~cm}^{-1}$ can be assigned to the vibration of $v_{\mathrm{as}} \mathrm{COO}$ in the molecule of the complex (1) in the gas phase, which means shifting up $37 \mathrm{~cm}^{-1}$ with regard to the compound (1) in the solid phase (Figure 5). The coordinated ethylamine vibrations bands were also identified at $2995 \mathrm{~cm}^{-1}$ $\left(v \mathrm{CH}_{3}\right), 3168 \mathrm{~cm}^{-1}\left(v \mathrm{NH}_{2}\right)$, and $1532 \mathrm{~cm}^{-1}\left(\delta \mathrm{NH}_{2}\right)$, which additionally confirmed the evaporation of the complex during heating. Interestingly, no bands characteristic of free ethylamine in the gas phase were observed in the spectra $\left(3345 \mathrm{~cm}^{-1}, 1620 \mathrm{~cm}^{-1}\right.$ [41]). The occurrence of the $\mathrm{vas}_{\mathrm{as}} \mathrm{COO}$ at $1759 \mathrm{~cm}^{-1}$ (shift towards higher values) indicates a change in the coordination mode from bidentate to unidentate [42] Combining this fact with the presence of the $\mathrm{vNH}_{2}$ at $3486 \mathrm{~cm}^{-1}$, the formation of the transitional copper(II) carboxylate complex with coordinated amido group $\left(\mathrm{NH}_{2}{ }^{-}\right)$in the gas phase, in which the coordination center is reduced to $\mathrm{Cu}(\mathrm{I})$ and a hydrazine-bridged complex is generated, has been proposed (Figure 6). A similar chemical reaction was observed for the nickel complexes. [43] The strongest registered signals came from the $v \mathrm{CF}$ stretching vibrations over the $1152-1203 \mathrm{~cm}^{-1}$ range.

In the next step, at the temperature of $553 \mathrm{~K}$, the band at $3035 \mathrm{~cm}^{-1}$ from the $v \mathrm{CH}_{3}$ stretching vibrations and at $1154 \mathrm{~cm}^{-1}$ from the $v C F$ stretching vibrations were registered. Ethyl trifluoroacetate was still observed in the gas phase. Moreover, the identified bands at $2345 \mathrm{~cm}^{-1}$ and $2172 \mathrm{~cm}^{-1}$ can be assigned to the $\mathrm{CO}_{2}$ and $\mathrm{CO}$ molecules, respectively. A band characteristic of aliphatic fluorinated compounds $\left(1029 \mathrm{~cm}^{-1}\right)$ was also detected. The above data analysis leads to a conclusion that the $\left[\mathrm{Cu}_{2}\left(\mathrm{EtNH}_{2}\right)_{2}\left(\mu-\mathrm{O}_{2} \mathrm{CCF}_{3}\right)_{4}\right]$ complex (1) exists from $473 \mathrm{~K}$ to $533 \mathrm{~K}$ in the gas phase. Over this temperature, the compound (1) disappeared, and the decomposition products mixture was formed. 


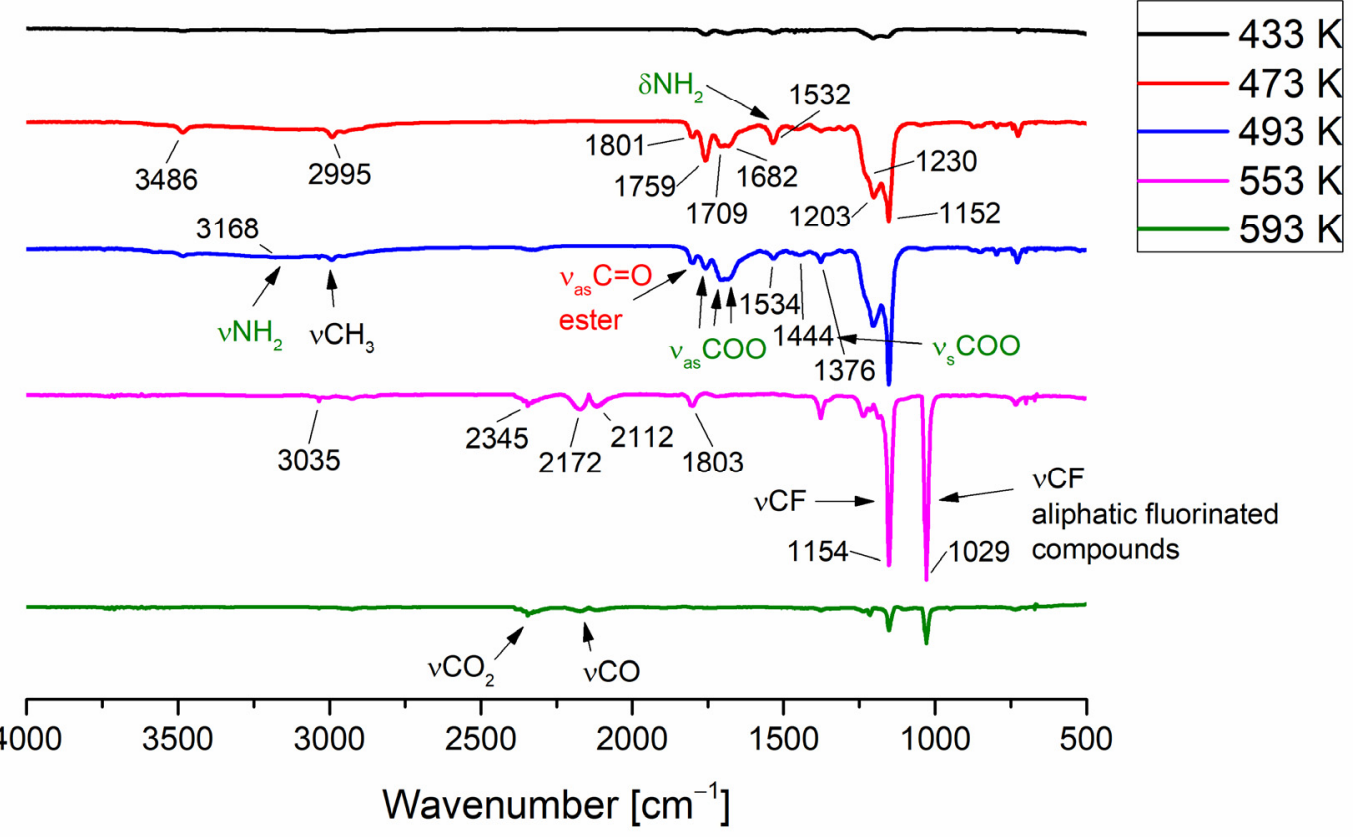

Figure 4. Temperature variable infrared spectra VT IR for the vapour formed during the $\left[\mathrm{Cu}_{2}\left(\mathrm{EtNH}_{2}\right)_{2}\left(\mu-\mathrm{O}_{2} \mathrm{CCF}_{3}\right)_{4}\right]$ complex (1) heating.

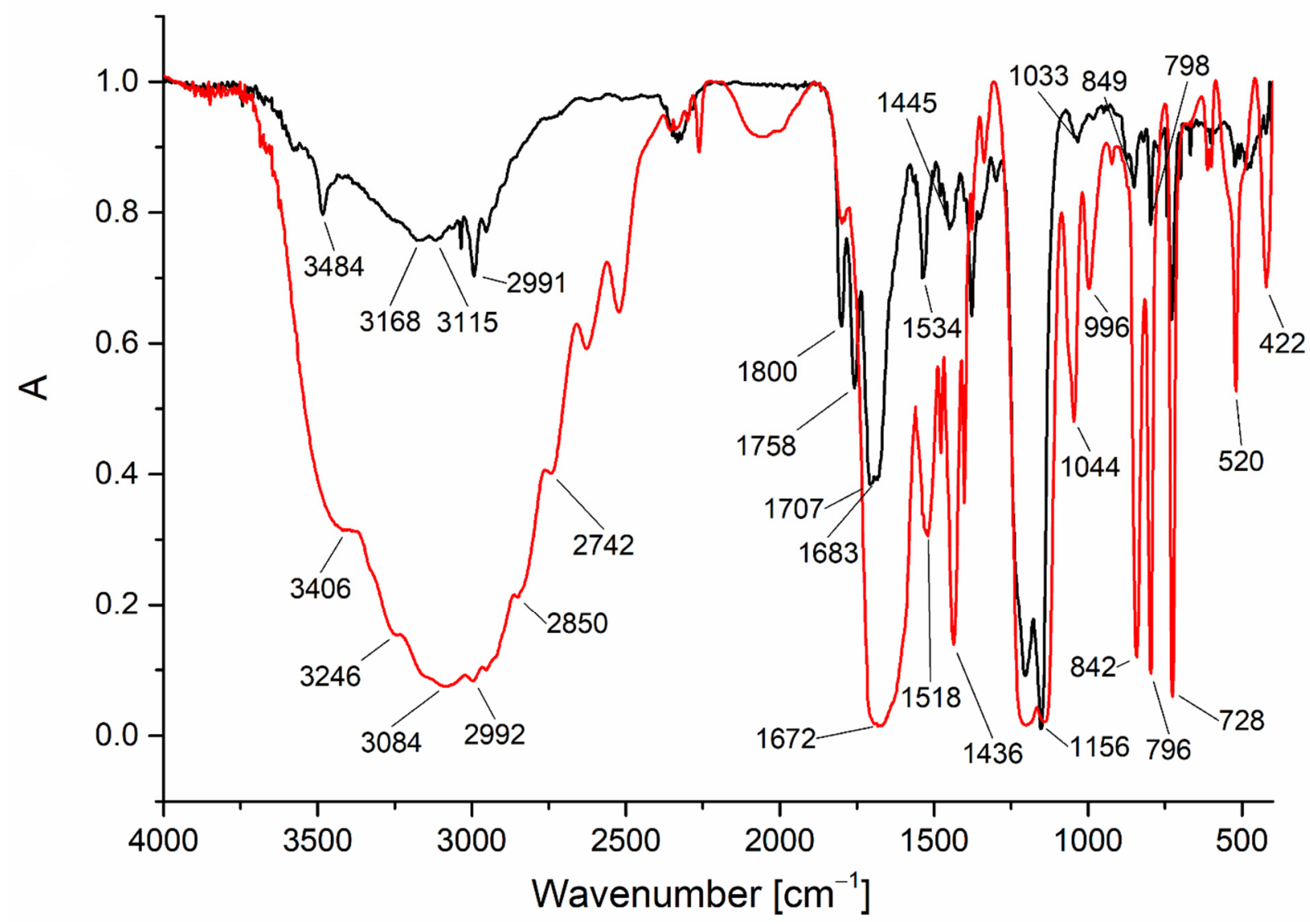

Figure 5. The spectra comparison for the $\left[\mathrm{Cu}_{2}\left(\mathrm{EtNH}_{2}\right)_{2}\left(\mu-\mathrm{O}_{2} \mathrm{CCF}_{3}\right)_{4}\right]$ complex $(\mathbf{1})$ in the solid-state (red line) and the gas phase at $493 \mathrm{~K}$ (black line).

Similar products in the gas phase were observed in the VT IR spectra for compounds (2), (4), (7), and (8). Bands characteristic of the studied complexes were noted for each 
of them, and they are also shifted towards higher values in relation to the signals in the solid phase (Figures S31-S36). In conclusion, the compounds with ethylamine evaporate in the temperature range $433-533 \mathrm{~K}$ but those with isopropylamine in the range $473-613 \mathrm{~K}$ (Table 5).

Table 5. Temperature ranges of occurrence of decomposition products in the gas phase for compounds (1), (2), (4), (7), and (8).

\begin{tabular}{cccccc}
\hline The Product & \multicolumn{4}{c}{ Temperature Range [K] } \\
\cline { 2 - 6 } in the Gas Phase & $\mathbf{( 1 )}$ & $\mathbf{( 2 )}$ & $\mathbf{( 4 )}$ & $\mathbf{( 7 )}$ & $\mathbf{( 8 )}$ \\
\hline$\left[\mathrm{Cu}_{2}\left(\mathrm{RNH}_{2}\right)_{2}\left(\mathrm{O}_{2} \mathrm{CR}_{\mathrm{f}}\right)_{4}\right]$ & $433-533$ & $463-513$ & $433-533$ & $493-533$ & $473-613$ \\
{$\left[\mathrm{Cu}_{2}\left(\mathrm{O}_{2} \mathrm{CR}_{\mathrm{f}}\right)_{4}\right]$} & $433-533$ & $463-513$ & $433-513$ & $433-533$ & $473-613$ \\
{$\left[\mathrm{Cu}_{2}\left(\mathrm{NH}_{2}\right)_{2}\left(\mathrm{O}_{2} \mathrm{CR}_{\mathrm{f}}\right)_{2}\right]$} & $433-533$ & $\geq 463$ & $473-533 *$ & $433-533$ & $\geq 473$ \\
$\mathrm{R}_{\mathrm{f}} \mathrm{COOR}$ & $433-573$ & $\geq 463$ & $\geq 433$ & $\geq 453$ & $533-613$ \\
$\mathrm{R}_{\mathrm{f}} \mathrm{COOH}$ & - & $473-513$ & - & $\geq 513$ & - \\
$\mathrm{CO}$ & $\geq 553$ & $\geq 413$ & $\geq 533$ & $\geq 493$ & $\geq 473$ \\
$\mathrm{CO}$ & $\geq 553$ & - & $533-553$ & $\geq 553$ & - \\
\hline
\end{tabular}

* Very low concentration.

The presence of carboxylic acid was identified for compounds (2) and (7) in the gas phase. In the case of the complex (2), relatively intense signals characteristic of water contamination in the gas phase were also observed in the spectra. Its presence may explain the formation of acid during decomposition. For the compound (7), the bands for water are not visible. The low intensity of the $v_{\mathrm{as}} \mathrm{COO}$ band for the acid testifies to its little concentration in the gas phase. Therefore, the water content in the gas phase may be so low that it is invisible in the spectra but sufficient to form an acid. In addition, for the complex (2), the formation of $\mathrm{CO}_{2}$ was detected at the temperature of $413 \mathrm{~K}$ before the appearance of metal carriers in the gas phase. In the case of the compound (4), the bands characteristic of copper carboxylates with a coordinated amide $\left(\mathrm{NH}_{2}{ }^{-}\right)$group were not registered. The possible mechanisms of the decomposition of the tested compounds are shown in Figure 6.

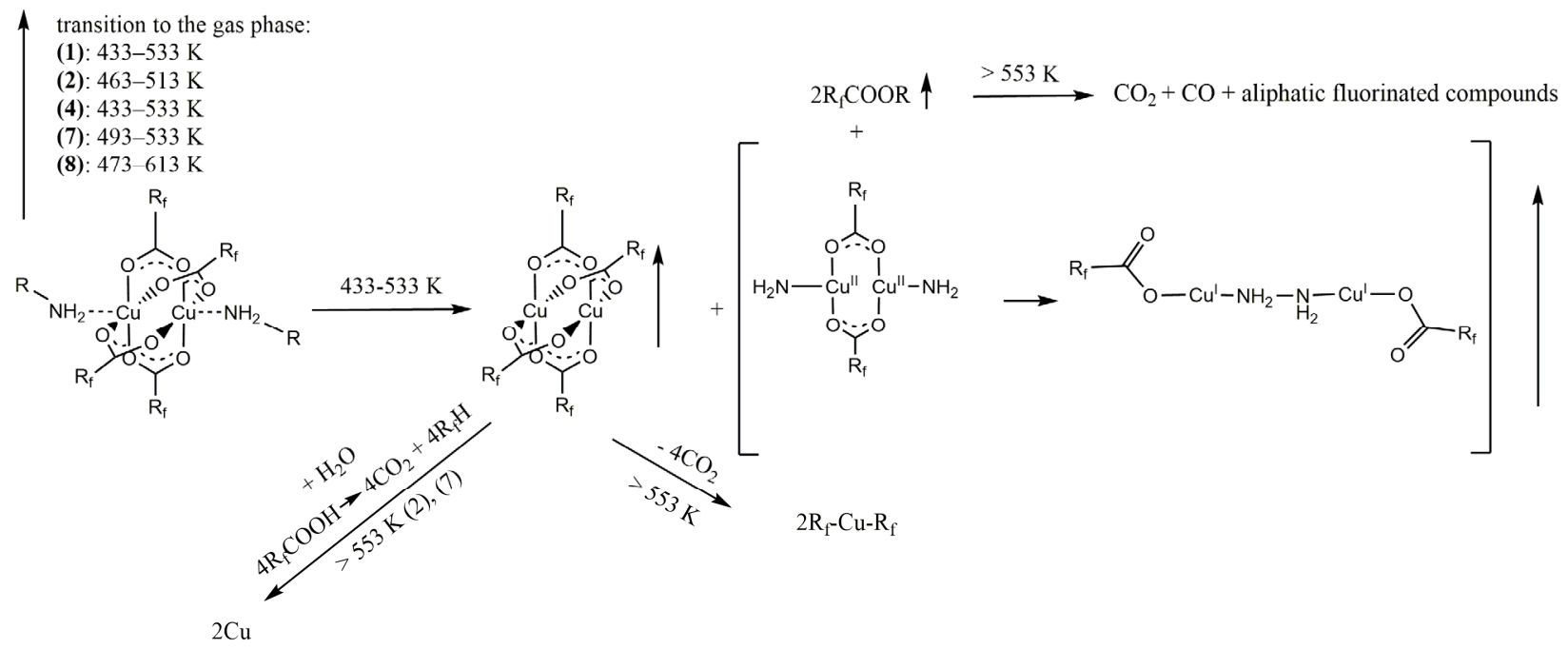

Figure 6. The thermal decomposition scheme for $\left[\mathrm{Cu}_{2}\left(\mathrm{RNH}_{2}\right)_{2}\left(\mu-\mathrm{O}_{2} \mathrm{CR}_{\mathrm{f}}\right)_{4}\right]$ compounds $(\mathbf{1}, \mathbf{2}, \mathbf{4}, \mathbf{7}$, and $\mathbf{8})$ based on VT IR results.

The intensity of bands registered above $3000 \mathrm{~cm}^{-1}$ in the VT IR spectra of the compounds (1), (2), (4), (7), and (8) was lower than that in the solid phase, which confirms that in the gas phase, the number of hydrogen bonds decreased, as expected. Comparing all the $\left[\mathrm{Cu}_{2}\left(\mathrm{RNH}_{2}\right)_{2}\left(\mu-\mathrm{O}_{2} \mathrm{CR}_{\mathrm{f}}\right)_{4}\right]$ complexes $\left(\mathrm{R}=\mathrm{Et},{ }^{\mathrm{i}} \mathrm{Pr},{ }^{\mathrm{t}} \mathrm{Bu}\right)$, the earlier described 
compound $\left[\mathrm{Cu}_{2}\left({ }^{\mathrm{t}} \mathrm{BuNH}_{2}\right)_{2}\left(\mu-\mathrm{O}_{2} \mathrm{CC}_{2} \mathrm{~F}_{5}\right)_{4}\right]$ with tert-butylamine $[9,10]$ has the lowest evaporation temperature $(413 \mathrm{~K})$. On the other hand, the gas-phase complex occurs in the widest temperature range, in the case of $\left[\mathrm{Cu}_{2}\left({ }^{\mathrm{i}} \mathrm{PrNH}_{2}\right)_{2}\left(\mu-\mathrm{O}_{2} \mathrm{CC}_{2} \mathrm{~F}_{5}\right)_{4}\right](8)$.

\subsection{CVD Experiments}

The above-mentioned studies in the gas phase indicated that from among the obtained complexes, $\left[\mathrm{Cu}_{2}\left(\mathrm{EtNH}_{2}\right)_{2}\left(\mu-\mathrm{O}_{2} \mathrm{CCF}_{3}\right)_{4}\right](\mathbf{1}),\left[\mathrm{Cu}_{2}\left(\mathrm{EtNH}_{2}\right)_{2}\left(\mu-\mathrm{O}_{2} \mathrm{CC}_{2} \mathrm{~F}_{5}\right)_{4}\right](\mathbf{2}),\left[\mathrm{Cu}_{2}\left({ }^{\mathrm{i}} \mathrm{PrNH}_{2}\right)_{2}\right.$ $\left.\left(\mu-\mathrm{O}_{2} \mathrm{CCF}_{3}\right)_{4}\right](7),\left[\mathrm{Cu}_{2}\left({ }^{\mathrm{i}} \mathrm{PrNH}_{2}\right)_{2}\left(\mu-\mathrm{O}_{2} \mathrm{CC}_{2} \mathrm{~F}_{5}\right)_{4}\right](8)$, and $\left[\mathrm{Cu}_{2}\left({ }^{\mathrm{i}} \mathrm{PrNH}_{2}\right)_{2}\left(\mu-\mathrm{O}_{2} \mathrm{CC}_{3} \mathrm{~F}_{7}\right)_{4}\right](9)$ revealed the best properties for the purposes of Chemical Vapor Deposition precursors formation. These are derivatives of the carboxylate ligands with shorter carbon chains (number of carbon atoms in the chain $\mathrm{n}=1-3)$. For all the selected compounds ((1), (2), (7), (8), and (9)), deposits were obtained by the CVD method. The vaporisation temperatures $\mathrm{T}_{\mathrm{V}}$ were $453 \mathrm{~K}(\mathbf{7})$ and $473 \mathrm{~K}(\mathbf{1}, \mathbf{2}, \mathbf{8}$, and $\mathbf{9})$, whereas the deposition temperatures $\mathrm{T}_{\mathrm{D}}$ values were from $573 \mathrm{~K}$ to $713 \mathrm{~K}$ (Table 6).

Table 6. Summary CVD conditions for experiments.

\begin{tabular}{|c|c|c|c|c|c|c|}
\hline & $\begin{array}{c}\text { Vaporization } \\
\text { Temperature } \\
T_{V}[K]\end{array}$ & $\begin{array}{c}\text { Deposition } \\
\text { Temperature } \\
T_{D}[K]\end{array}$ & $\begin{array}{l}\text { Precursor Mass } \\
\quad(\mathrm{m})[\mathrm{mg}]\end{array}$ & Carrier Gas & Substrate & $\begin{array}{l}\text { Deposition Time } \\
\text { (t) }[\mathrm{min}]\end{array}$ \\
\hline$\left[\mathrm{Cu}_{2}\left(\mathrm{EtNH}_{2}\right)_{2}\left(\mu-\mathrm{O}_{2} \mathrm{CCF}_{3}\right)_{4}\right](\mathbf{1})$ & 473 & 573 & 80 & \multirow{5}{*}{$\mathrm{Ar}$} & \multirow{5}{*}{$\operatorname{Si}(111)$} & \multirow{5}{*}{60} \\
\hline$\left[\mathrm{Cu}_{2}\left(\mathrm{EtNH}_{2}\right)_{2}\left(\mu-\mathrm{O}_{2} \mathrm{CC}_{2} \mathrm{~F}_{5}\right)_{4}\right](2)$ & 473 & 713 & 100 & & & \\
\hline$\left[\mathrm{Cu}_{2}\left({ }^{\mathrm{i}} \mathrm{PrNH}_{2}\right)_{2}\left(\mu-\mathrm{O}_{2} \mathrm{CCF}_{3}\right)_{4}\right](7)$ & 453 & 573 & 80 & & & \\
\hline$\left[\mathrm{Cu}_{2}\left({ }^{\mathrm{i}} \mathrm{PrNH}_{2}\right)_{2}\left(\mu-\mathrm{O}_{2} \mathrm{CC}_{2} \mathrm{~F}_{5}\right)_{4}\right](8)$ & 473 & 713 & 100 & & & \\
\hline$\left[\mathrm{Cu}_{2}\left({ }^{\mathrm{i}} \mathrm{PrNH}_{2}\right)_{2}\left(\mu-\mathrm{O}_{2} \mathrm{CC}_{3} \mathrm{~F}_{7}\right)_{4}\right](9)$ & 473 & 673 & 100 & & & \\
\hline
\end{tabular}

The surface morphology of the formed deposits from the complex $\left[\mathrm{Cu}_{2}\left(\mathrm{EtNH}_{2}\right)_{2}(\mu-\right.$ $\left.\left.\mathrm{O}_{2} \mathrm{CCF}_{3}\right)_{4}\right]$ (1) is differentiated due to the size, shape, and density of the objects (Figure 7) and depends on the length of the transport pathway in the CVD reactor. On the first covered silicone substrate (Figure 7a), sparsely distributed nanowires with the length of $300 \mathrm{~nm}$ to $800 \mathrm{~nm}$ in length and around $50 \mathrm{~nm}$ to $90 \mathrm{~nm}$ in diameter were observed. Instead, the surface of the sample (Figure $7 \mathrm{~b}$ ) is covered by a heterogeneous and rough deposit layer on which a few nanoparticles of $80 \mathrm{~nm}$ in diameter were visible. The surface of the next deposit (Figure 7c) is most different from the other two because it is covered by grains with of $40 \mathrm{~nm}$ to $70 \mathrm{~nm}$ in diameter that overlap in some areas.

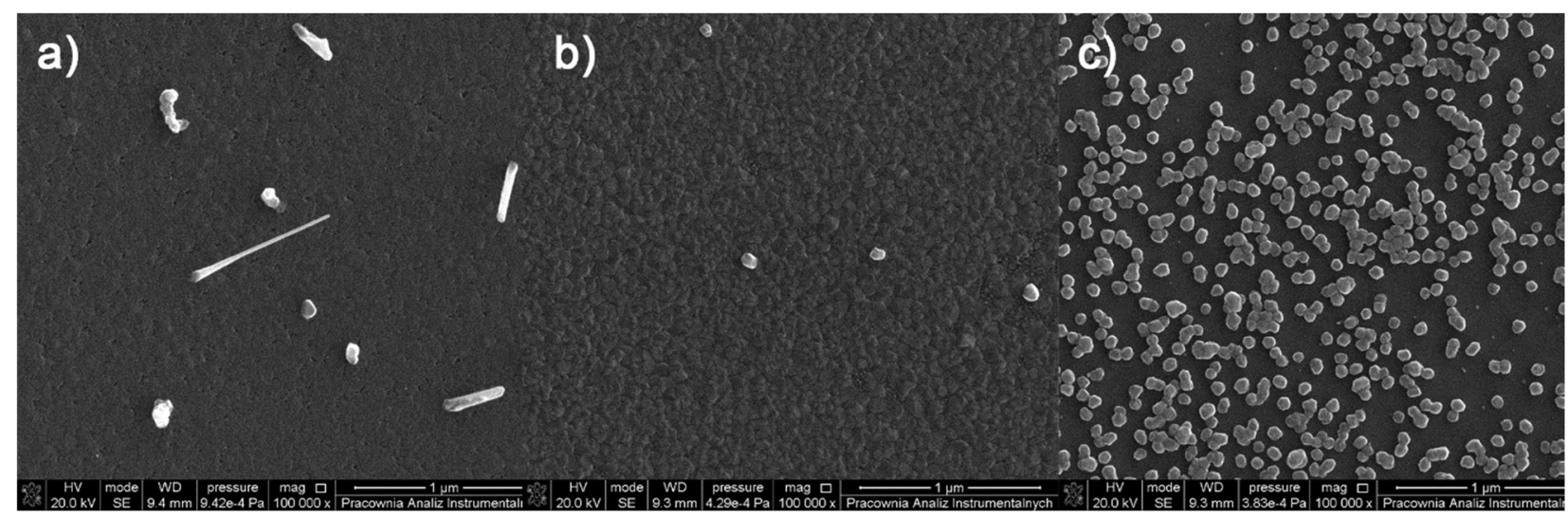

Figure 7. SEM images of deposits for the precursor $\left[\mathrm{Cu}_{2}\left(\mathrm{EtNH}_{2}\right)_{2}\left(\mu-\mathrm{O}_{2} \mathrm{CCF}_{3}\right)_{4}\right](\mathbf{1}), \mathrm{Mag}=100,000 \times((\mathbf{a}-\mathbf{c})-$ orderly with the increasing transport way), $\mathrm{T}_{\mathrm{V}}=473 \mathrm{~K}, \mathrm{~T}_{\mathrm{D}}=573 \mathrm{~K}, \mathrm{Si}(111)$, Ar.

SEM images (Figure 8) for the compound $\left[\mathrm{Cu}_{2}\left(\mathrm{EtNH}_{2}\right)_{2}\left(\mu-\mathrm{O}_{2} \mathrm{CC}_{2} \mathrm{~F}_{5}\right)_{4}\right](2)$ show that the surface morphology of the obtained materials is diversified. The dependence of the 
deposit morphology on the length of the transport pathway of the precursor is evident. The coverage silicone substrate (a) (Figure 8a) morphology is extremely interesting. It consists of densely packed vertical copper nanorods with a diameter of 60 to $150 \mathrm{~nm}$ in diameter and approximately $500 \mathrm{~nm}$ in length. The material (b) (Figure 8b) is composed of densely packed grains with a size of $60-150 \mathrm{~nm}$ in size, which begin to interconnect with each other. The deposit (Figure 8c) shows that the grains virtually completely coalesce with the formation of a continuous layer. Considering data for the morphology of the obtained materials, it was found that the grains merged more and more intensively with the extension of the transport way.

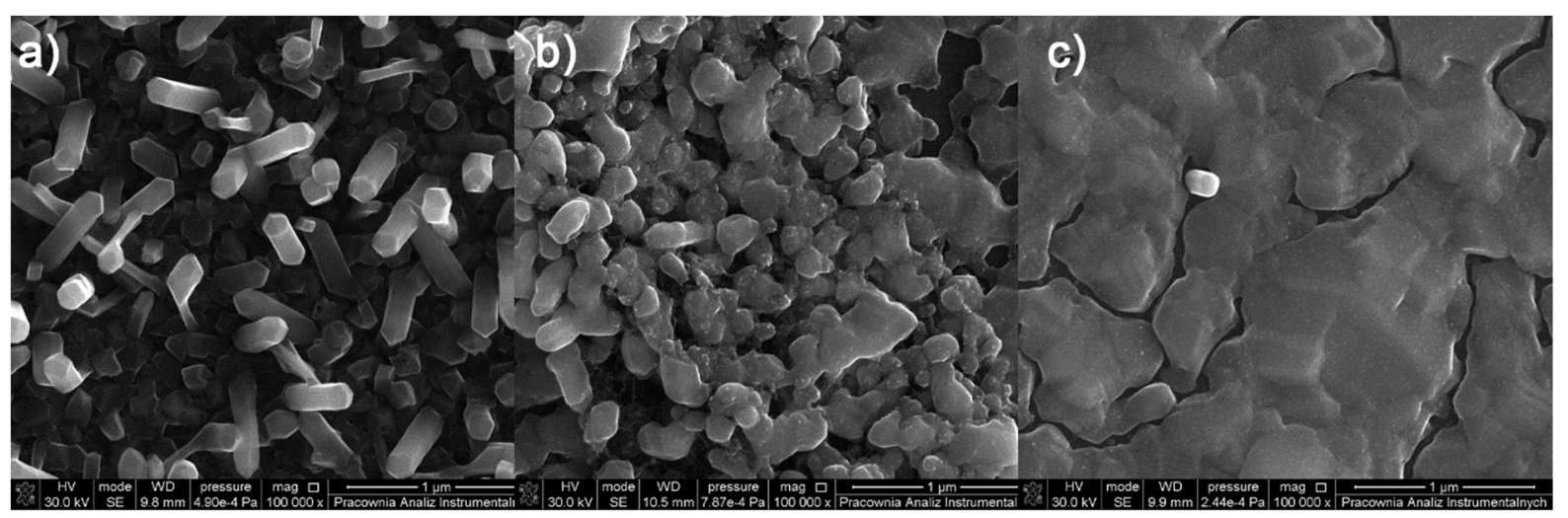

Figure 8. SEM pictures of deposits for the precursor $\left[\mathrm{Cu}_{2}\left(\mathrm{EtNH}_{2}\right)_{2}\left(\mu-\mathrm{O}_{2} \mathrm{CC}_{2} \mathrm{~F}_{5}\right)_{4}\right](2), \mathrm{Mag}=150,000 \times,((\mathbf{a}-\mathbf{c})$-orderly with the increasing transport way), $\mathrm{T}_{\mathrm{V}}=473 \mathrm{~K}, \mathrm{~T}_{\mathrm{D}}=713 \mathrm{~K}, \mathrm{Si}(111)$, Ar.

In order to check the effect of an amine on the type of deposits formed in the CVD process, complexes containing ${ }^{i} \mathrm{PrNH}_{2}$ in the axial position were also used. The surface morphology of the obtained materials $(\mathrm{a}, \mathrm{b}, \mathrm{c})$ (Figure 9) for the complex $\left[\mathrm{Cu}_{2}\left({ }^{\mathrm{i}} \mathrm{PrNH}_{2}\right)_{2}(\mu-\right.$ $\left.\left.\mathrm{O}_{2} \mathrm{CCF}_{3}\right)_{4}\right]$ (7) is heterogeneous. The $\mathrm{Si}(111)$ substrate (a) is covered by a rugged film on which oblong elements are visible. The deposit (b) consists of clusters of elements forming a rough surface. A similar situation is observed for the cover (c) but, this surface is even less homogeneous, and the areas with holes are visible.

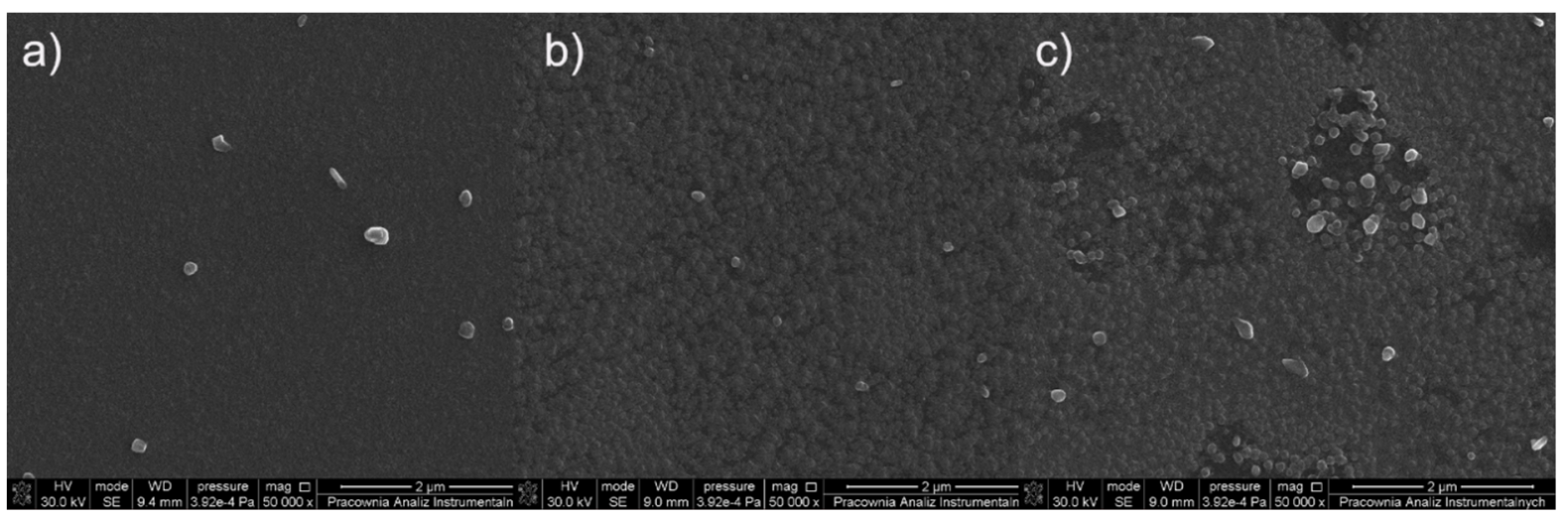

Figure 9. SEM pictures of deposits for the precursor $\left[\mathrm{Cu}_{2}\left({ }^{\mathrm{i} P r N H_{2}}\right)_{2}\left(\mu-\mathrm{O}_{2} \mathrm{CCF}_{3}\right)_{4}\right](7), \mathrm{Mag}=50,000 \times,((\mathbf{a}-\mathbf{c})$-orderly with the increasing transport way), $\mathrm{T}_{\mathrm{V}}=453 \mathrm{~K}, \mathrm{~T}_{\mathrm{D}}=573 \mathrm{~K}, \mathrm{Si}(111)$, Ar.

As for the complex (2), in the case of the deposits obtained for the complex $\left[\mathrm{Cu}_{2}\left({ }^{\mathrm{i} P r N H}\right)_{2}\right.$ $\left.\left(\mu-\mathrm{O}_{2} \mathrm{CC}_{2} \mathrm{~F}_{5}\right)_{4}\right](8)$ (Figure 10), the influence of the precursor transport way on the surface morphology and the formation of nanowires was observed. However, when the compound (8) was used, the obtained nanorods were overgrown with droplet-shaped grains with a size of $80-200 \mathrm{~nm}$ in size (Figure 10a,b). The size of the nanorods (a) was 50-150 nm in 
diameter and about $900 \mathrm{~nm}$ in length, but the structures (b) were $20-50 \mathrm{~nm}$ in diameter and 500-900 $\mathrm{nm}$ in length. In the formed deposit (c), the packed grains with in size of $140-300 \mathrm{~nm}$ and nanorods in diameter of 30-70 $\mathrm{nm}$ and about 300-600 nm in length were grown.

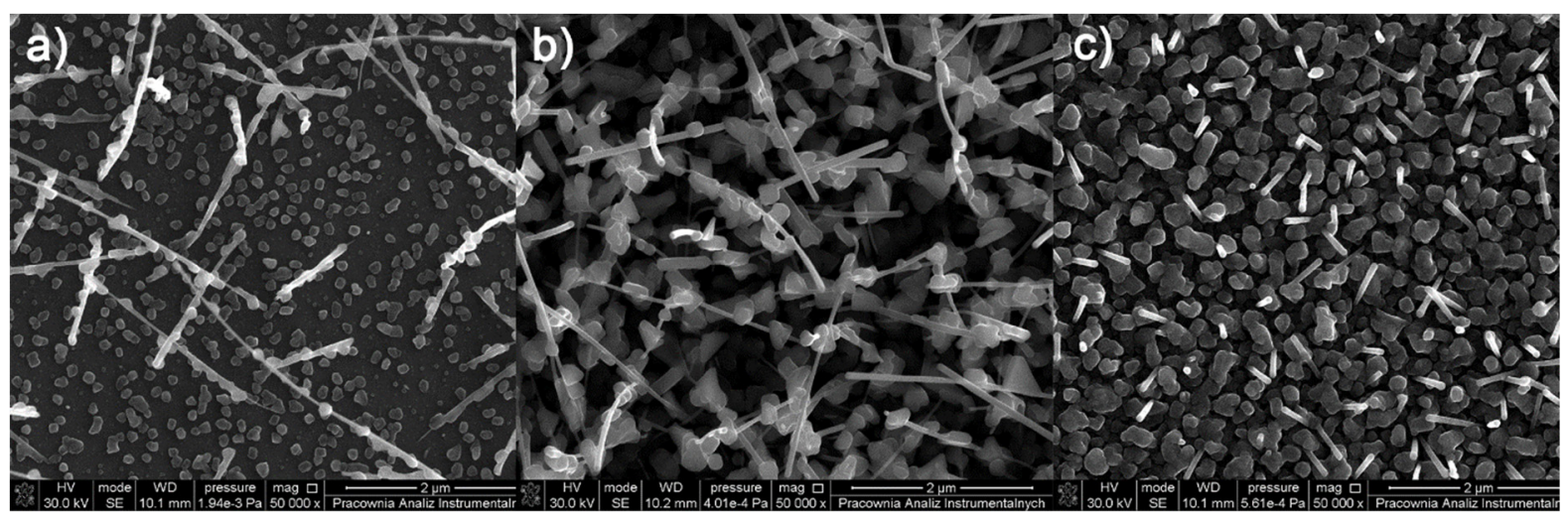

Figure 10. SEM pictures of deposits for the precursor $\left[\mathrm{Cu}_{2}\left({ }^{\mathrm{i}} \mathrm{PrNH}_{2}\right)_{2}\left(\mu-\mathrm{O}_{2} \mathrm{CC}_{2} \mathrm{~F}_{5}\right)_{4}\right](\mathbf{8}), \mathrm{Mag}=50,000 \times,((\mathbf{a}-\mathbf{c})-$ orderly with the increasing transport pathway), $\mathrm{T}_{\mathrm{V}}=473 \mathrm{~K}, \mathrm{~T}_{\mathrm{D}}=713 \mathrm{~K}, \mathrm{Si}(111)$, Ar.

Morphology of the compound $\left[\mathrm{Cu}_{2}\left({ }^{\mathrm{i}} \mathrm{PrNH}_{2}\right)_{2}\left(\mu-\mathrm{O}_{2} \mathrm{CC}_{3} \mathrm{~F}_{7}\right)_{4}\right]$ (9) deposits (Figure 11) is also heterogeneous. On the surface (a), rods of about $1 \mu \mathrm{m}$ and single grains are visible. The substrate $(b)$ is covered by grains differing in shape $(100-180 \mathrm{~nm})$ and round, smaller elements (approx. 50nm in diameter) between which single rods are visible. In comparison, surface (c) is uniformly coated by small and round grains $(30-80 \mathrm{~nm})$.

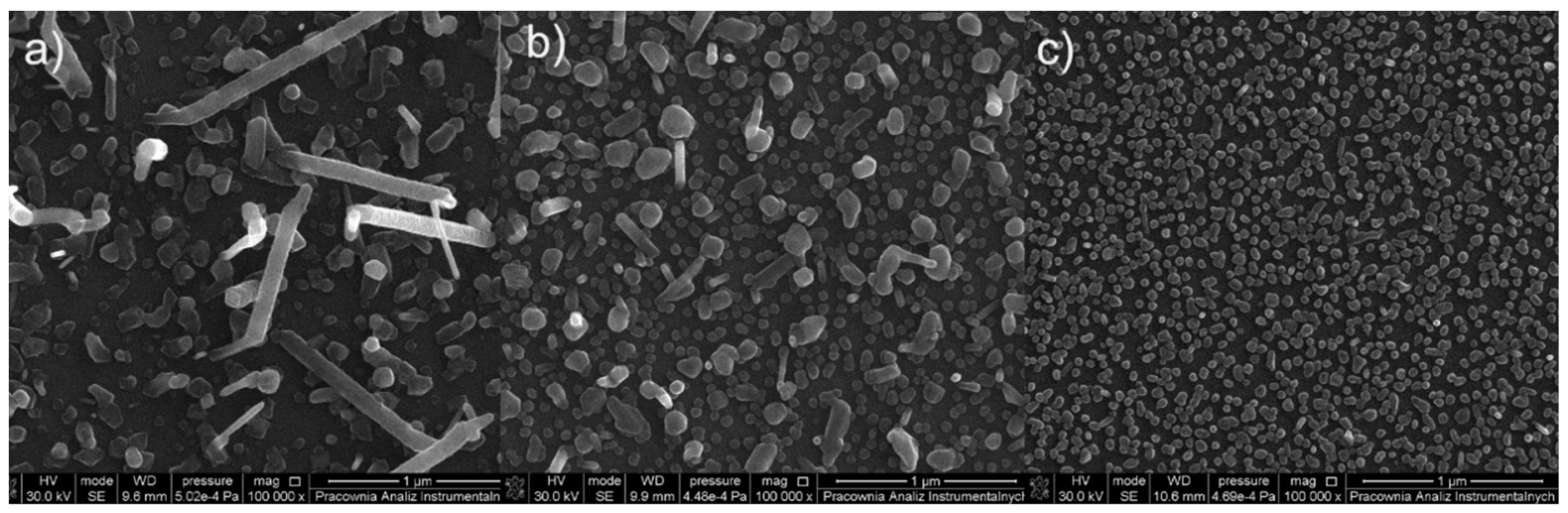

Figure 11. SEM pictures of deposits for the precursor $\left[\mathrm{Cu}_{2}\left({ }^{\mathrm{i} P r N H}\right)_{2}\left(\mu-\mathrm{O}_{2} \mathrm{CC}_{3} \mathrm{~F}_{7}\right)_{4}\right](\mathbf{9}), \mathrm{Mag}=100,000 \times,((\mathbf{a}-\mathbf{c})-\mathrm{orderly}$ with the increasing transport way), $\mathrm{T}_{\mathrm{V}}=473 \mathrm{~K}, \mathrm{~T}_{\mathrm{D}}=673 \mathrm{~K}, \mathrm{Si}(111)$, Ar.

The EDX spectra (Figure 12) confirm the presence of copper in the obtained deposits. For the majority of materials, signals from oxygen, nitrogen, carbon, and fluorine, of which the precursor was composed of which, were not observed in the spectra. A slight peak corresponding to oxygen was recorded for the cover obtained from the complex (7). It may be due to the formation of small amounts of copper oxide. In all the cases, the evaporation temperatures were similar as opposed to the deposition temperatures. In the case of the precursors (2) and (8), the copper signal in the spectrum is the most intense because the resulting covers contain a densely packed material. This result may due to the better transport of the metal carriers in the gas phase and the higher decomposition temperature used. 


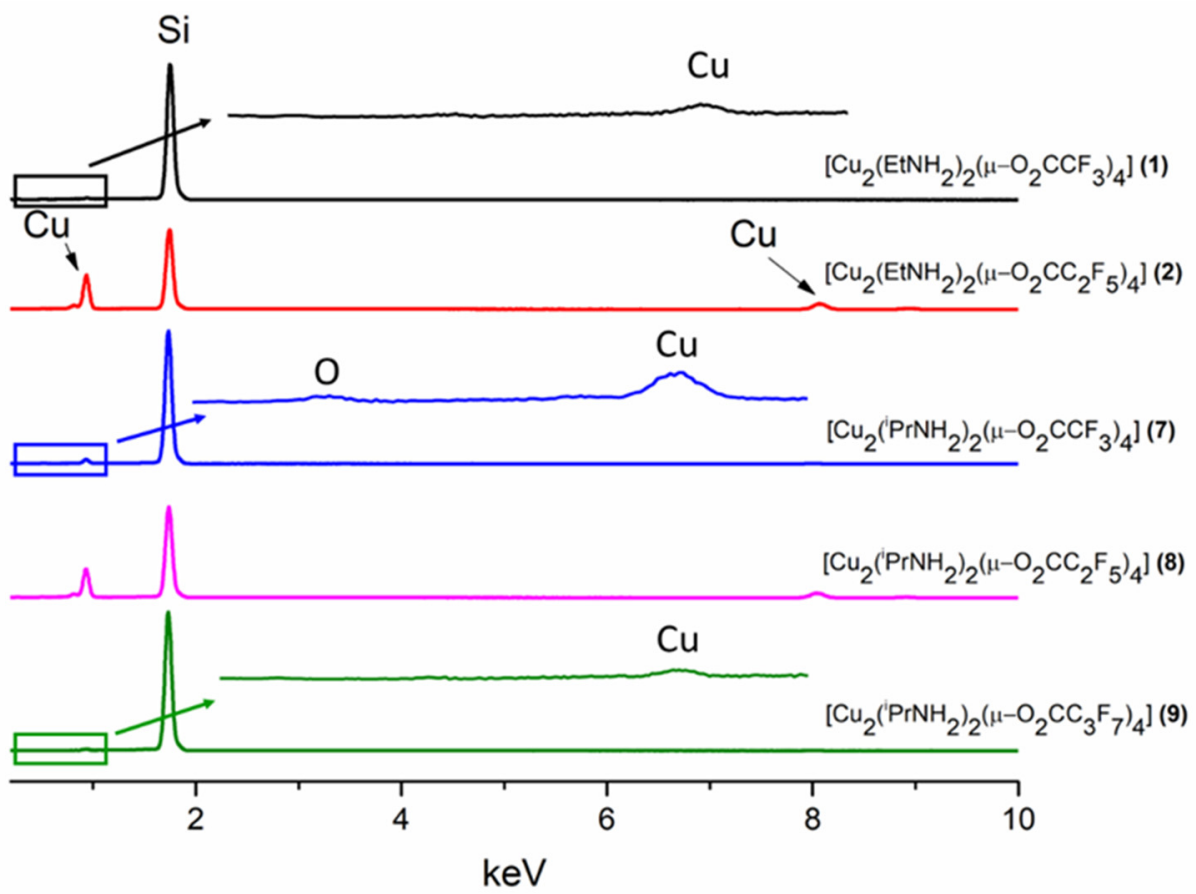

Figure 12. Composition analysis of the obtained materials using precursors: $\left[\mathrm{Cu}_{2}\left(\mathrm{EtNH}_{2}\right)_{2}(\mu-\right.$ $\left.\left.\mathrm{O}_{2} \mathrm{CCF}_{3}\right)_{4}\right]$ (1) (black line), $\left[\mathrm{Cu}_{2}\left(\mathrm{EtNH}_{2}\right)_{2}\left(\mu-\mathrm{O}_{2} \mathrm{CC}_{2} \mathrm{~F}_{5}\right)_{4}\right]$ (2) (red line), $\left[\mathrm{Cu}_{2}\left({ }^{\mathrm{i}}{ }^{\mathrm{PrNH}}{ }_{2}\right)_{2}\left(\mu-\mathrm{O}_{2} \mathrm{CCF}_{3}\right)_{4}\right](7)$ (blue line), $\left[\mathrm{Cu}_{2}\left({ }^{\mathrm{i}} \mathrm{PrNH}_{2}\right)_{2}\left(\mu-\mathrm{O}_{2} \mathrm{CC}_{2} \mathrm{~F}_{5}\right)_{4}\right]$ (8) (pink line), $\left[\mathrm{Cu}_{2}\left({ }^{\mathrm{i}} \mathrm{PrNH}_{2}\right)_{2}\left(\mu-\mathrm{O}_{2} \mathrm{CC}_{3} \mathrm{~F}_{7}\right)_{4}\right]$ (9) (green line).

\subsection{Spin- and Dip-Coating Deposition}

Since the first preliminary attempts to deposit nanomaterials using the ethylamine derivative in the CVD method failed, dip- and spin-coating methods were used to prepare thin layers of the gel-like copper complexes on a silicon substrate. The thus fabricated materials were then heated to decompose the compounds to produce thin copper oxide or copper layers.

\subsubsection{Spin-Coated Materials}

In the case of the $\left[\mathrm{Cu}_{2}\left(\mathrm{EtNH}_{2}\right)_{2}\left(\mu-\mathrm{O}_{2} \mathrm{CC}_{3} \mathrm{~F}_{7}\right)_{4}\right]$ complex (3) deposited on the Si substrate (at $1100 \mathrm{rpm}, 30 \mathrm{~s}$ ), the copper compound covered the surface evenly-in the dots shape (Figure 13). The phase AFM images show homogeneity of the covers (Figure 14a). One area of the complex layer was observed. The height (thickness) of the layers ranged from 2.5 to $25 \mathrm{~nm}$.
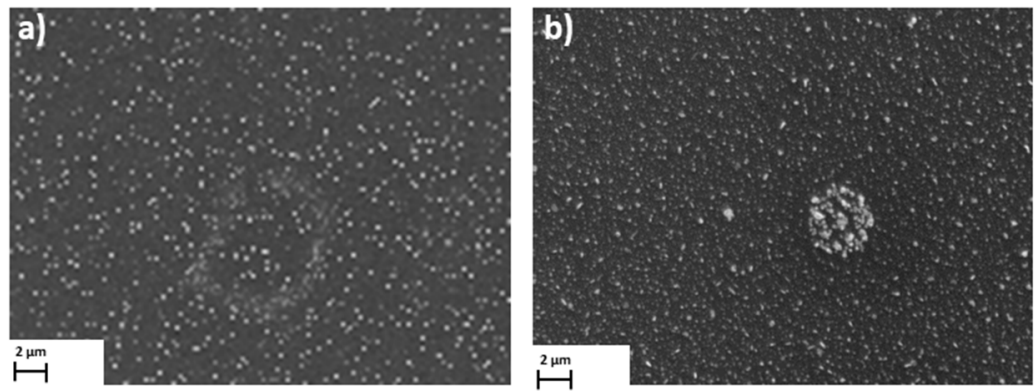

Figure 13. SEM images of $\left[\mathrm{Cu}_{2}\left(\mathrm{EtNH}_{2}\right)_{2}\left(\mu-\mathrm{O}_{2} \mathrm{CC}_{3} \mathrm{~F}_{7}\right)_{4}\right](3) / \mathrm{Si}(\mathbf{a})$ before, $(\mathbf{b})$ after heating Mag $=$ $10,000 \times(1100 \mathrm{rpm}, 30 \mathrm{~s})$.

After annealing, the dots become flatter and more extensive. The roughness parameters achieved $\mathrm{R}_{\mathrm{a}}=2.46 \mathrm{~nm}, \mathrm{R}_{\mathrm{q}}=2.14 \mathrm{~nm}$ before heating, and $\mathrm{R}_{\mathrm{a}}=8.76 \mathrm{~nm}, \mathrm{R}_{\mathrm{q}}=27.50 \mathrm{~nm}$ 
after heating, which points to the roughness increasing after the complex thermal decomposition Figure 14b.

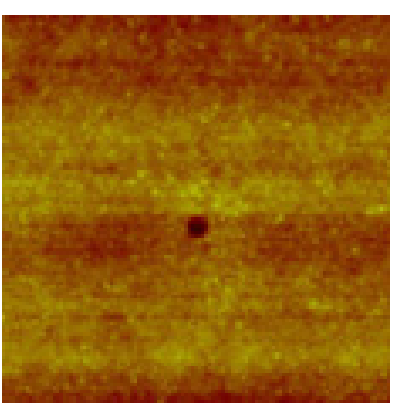

height

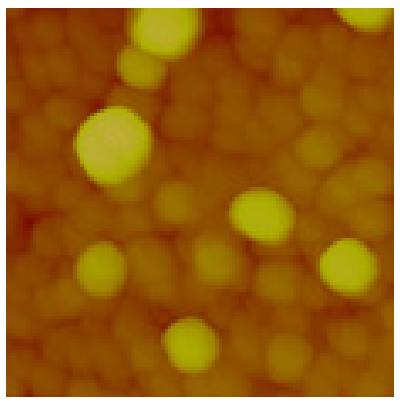

height

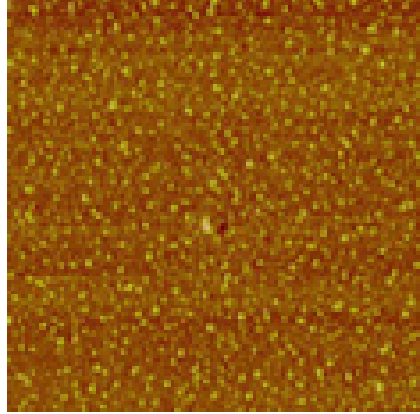

phase

(a) before heating

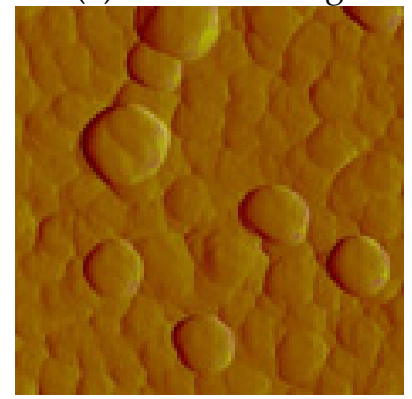

phase

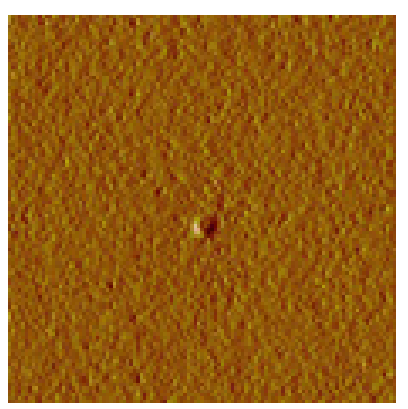

amplitude

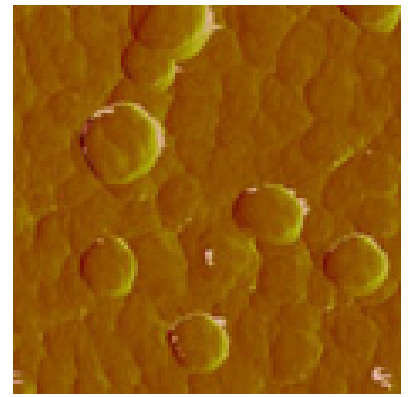

amplitude

(b) after heating

Figure 14. AFM images of $\left[\mathrm{Cu}_{2}\left(\mathrm{EtNH}_{2}\right)_{2}\left(\mu-\mathrm{O}_{2} \mathrm{CC}_{3} \mathrm{~F}_{7}\right)_{4}\right](\mathbf{3}) / \mathrm{Si}(\mathbf{a})$ before, (b) after heating (1100 rpm, $\left.30 \mathrm{~s}\right)$.

The application of the $\left[\mathrm{Cu}_{2}\left(\mathrm{EtNH}_{2}\right)_{2}\left(\mu-\mathrm{O}_{2} \mathrm{CC}_{2} \mathrm{~F}_{5}\right)_{4}\right]$ complex (2) on $\mathrm{Si}(111)$ in the multistage spin coating process gave the formation of a new type of layers type, in which small islands of the compound occasionally appeared. The size of these islands did not exceed $1 \mu \mathrm{m}$. Depending on the spin coating conditions, the films with different arrangements were obtained. The complex formed grains of regular size and covered the surface evenly without empty spaces. The layer was smooth with $R_{a}=1.78 \mathrm{~nm}$, $\mathrm{R}_{\mathrm{q}}=2.37 \mathrm{~nm}$, and $15 \mathrm{~nm}$ thick. Similar to how it was observed for the $\left[\mathrm{Cu}_{2}\left(\mathrm{EtNH}_{2}\right)_{2}(\mu-\right.$ $\left.\left.\mathrm{O}_{2} \mathrm{CC}_{3} \mathrm{~F}_{7}\right)_{4}\right]$ (3) materials, SEM analysis indicated the presence of the small crystallites in the complex surface.

After heating, the size of the grains increased, and sometimes the empty spaces appeared; the cracks were also noted resulting in inhomogeneous cover (Figure 15). This fact influenced the surface roughness, and the parameters $R_{a}$ and $R_{q}$ increased significantly, achieving $15.1 \mathrm{~nm}$ and $18.7 \mathrm{~nm}$, respectively. Generally, the roughness of the obtained layers increased after annealing (Figure 16). Additionally, after heating the layers, the defects (spaces between compounds structures) increased twice from about $60 \mathrm{~nm}$ to $120 \mathrm{~nm}$. As a consequence, the discontinuity of the films was observed. Different film thicknesses can be explained by the above-mentioned spin coating process as a result of which defects upon heating can be produced. Unequal evaporation of the in situ formed reaction products leads to partially cracked films of copper compounds films. A similar phenomenon was observed in the case of other copper and silver complexes [44]. 


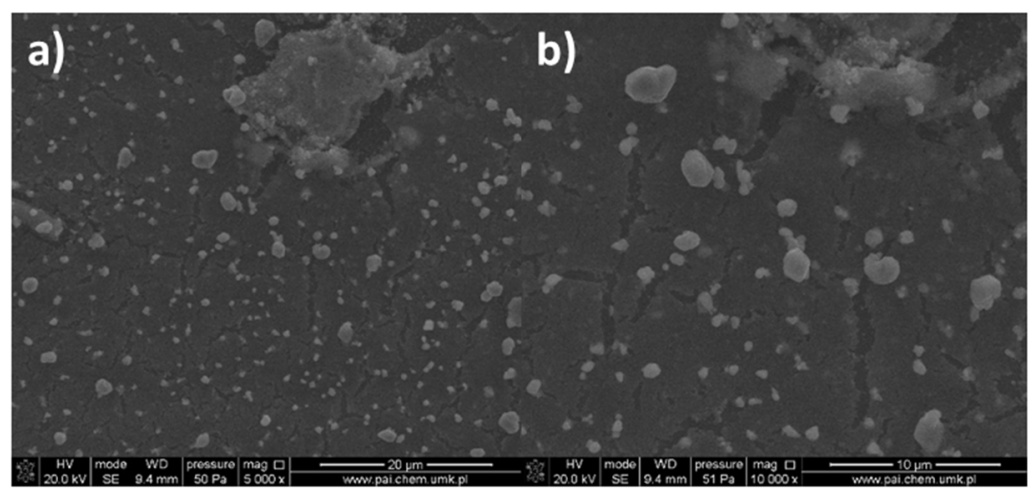

Figure 15. SEM images of $\left[\mathrm{Cu}_{2}\left(\mathrm{EtNH}_{2}\right)_{2}\left(\mu-\mathrm{O}_{2} \mathrm{CC}_{2} \mathrm{~F}_{5}\right)_{4}\right](2) / \mathrm{Si}$ after heating, $\mathrm{Cu} 5.53$ wt.\%, O 10.48 wt.\%, (800 rpm, $10 \mathrm{~s}, 600 \mathrm{rpm}, 10 \mathrm{~s} \times 2$, drying $3000 \mathrm{rpm}, 60 \mathrm{~s})(\mathbf{a}) \mathrm{Mag}=5000 \times(\mathbf{b})$ Mag $=10,000 \times$.

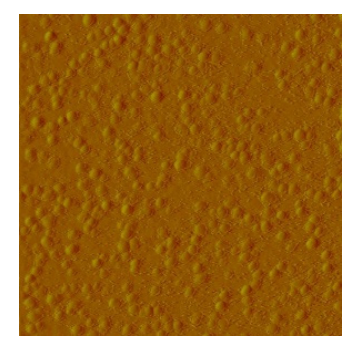

amplitude

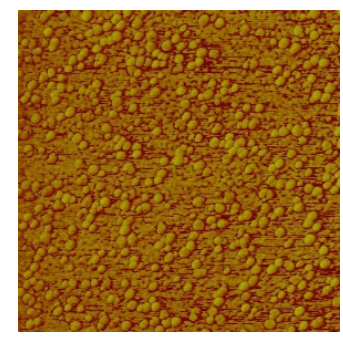

phase

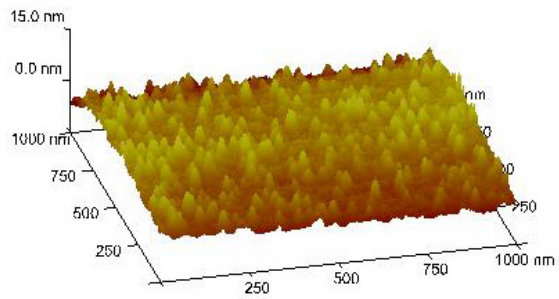

(a)

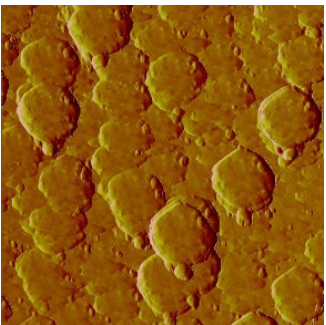

amplitude

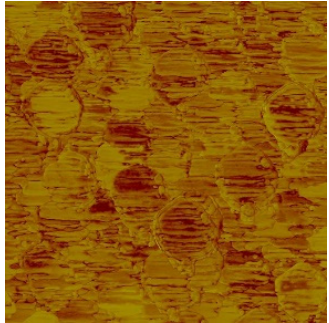

phase

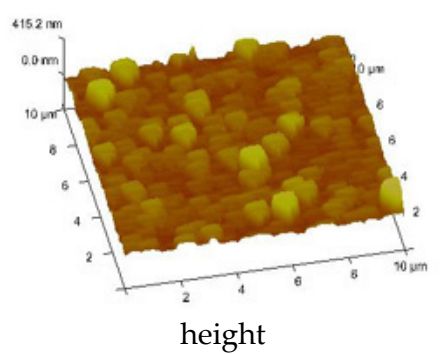

(b)

Figure 16. AFM images of $\left[\mathrm{Cu}_{2}\left(\mathrm{EtNH}_{2}\right)_{2}\left(\mu-\mathrm{O}_{2} \mathrm{CC}_{2} \mathrm{~F}_{5}\right)_{4}\right](2) / \mathrm{Si}(\mathbf{a})$ before, $(\mathbf{b})$ after heating (multistage process: 800 rpm, $10 \mathrm{~s}, 600 \mathrm{rpm}, 10 \mathrm{~s}, 600 \mathrm{rpm}, 10 \mathrm{~s}$, drying $3000 \mathrm{rpm}, 60 \mathrm{~s}$ ). 
EDX results for the $\left[\mathrm{Cu}_{2}\left(\mathrm{EtNH}_{2}\right)_{2}\left(\mu-\mathrm{O}_{2} \mathrm{CC}_{3} \mathrm{~F}_{7}\right)_{4}\right](3) / \mathrm{Si}$ material formed at the spin speed $1000 \mathrm{rpm}$ and time of coating $30 \mathrm{~s}$ were: $\mathrm{Cu} 1.69 ; \mathrm{N}$ 9.80; $\mathrm{F} 10.44 ; \mathrm{O} 5.0 / \mathrm{Cu} 2.10 ; \mathrm{O}$ $6.11 \mathrm{wt} . \%$ (before/after heating). The same phenomenon was observed for $\left[\mathrm{Cu}_{2}\left(\mathrm{EtNH}_{2}\right)_{2}(\mu-\right.$ $\left.\left.\mathrm{O}_{2} \mathrm{CC}_{2} \mathrm{~F}_{5}\right)_{4}\right] / \mathrm{Si}(2)$ material (1100 rpm $30 \mathrm{~s}$ ), and the following amount of copper: $0.78 \mathrm{wt} . \%$ before and $1.05 \mathrm{wt} . \%$ after heating were found. Moreover, the punctual copper quantity was much higher and achieved $20.4 \mathrm{wt} . \%$. This situation results from the heating and an irregularly arrangement of a compound on the substrate surface (the presence of local islands of compounds). After heating, only $\mathrm{Cu}$ and $\mathrm{O}$ elements were detected as the result of the copper complex thermal decomposition. The lack of fluorine and nitrogen signals indicated the most probable formation of $\mathrm{CuO}$ as the final product. According to our expectations, the relative concentration of copper in the layers increased after heating. The above discussion suggests that the quality of the layer (uniformity, roughness) can be optimised by the spin speed and deposition time variation.

\subsubsection{Dip-Coated Materials}

Dip coating was the second method used to obtain thin layers of both complexes (2) and (3). Considering the essential factors affecting the formation and quality of the fabricated covers, the effect of the following parameters was taken into account: the number of coating counts (varied from 5 to 30), immersion rate (from 20 to $80 \mathrm{~mm} / \mathrm{min}$ ), and the immersion time (over 5-120 s). Selected from among twenty-one, the four different sets of process parameters, for which the deposition effects were most promising, were chosen (Table 7). The influence of coating counts on the properties of the $\left[\mathrm{Cu}_{2}\left(\mathrm{EtNH}_{2}\right)_{2}(\mu-\right.$ $\left.\left.\mathrm{O}_{2} \mathrm{CC}_{2} \mathrm{~F}_{5}\right)_{4}\right](2)$ layers were studied as well.

Table 7. The list of selected parameters of the dip-coating process for the best quality layers of $\left[\mathrm{Cu}_{2}\left(\mathrm{EtNH}_{2}\right)_{2}\left(\mu-\mathrm{O}_{2} \mathrm{CC}_{3} \mathrm{~F}_{7}\right)_{4}\right](3)$.

\begin{tabular}{cccc}
\hline Set Number & $\begin{array}{c}\text { Coating } \\
\text { Counts }\end{array}$ & $\begin{array}{c}\text { Immersion Rate } \\
{[\mathbf{m m} / \mathbf{m i n}]}\end{array}$ & Immersion Time[s] \\
\hline 1 & 10 & 80 & 5 \\
\hline 2 & 10 & 80 & 20 \\
\hline 3 & 10 & 80 & 30 \\
\hline 4 & 30 & 80 & 10 \\
\hline
\end{tabular}

Again, the complex layers were heated to obtain copper oxide or thin copper materials.

AFM results showed evenly distributed copper complexes on the silicon surface and layers without discontinuities. The phase AFM images exhibited only one area of the complex layers (Figures 17 and 18).

The covers of $\left[\mathrm{Cu}_{2}\left(\mathrm{EtNH}_{2}\right)_{2}\left(\mu-\mathrm{O}_{2} \mathrm{CC}_{3} \mathrm{~F}_{7}\right)_{4}\right]$ (3) obtained at the immersion time $30 \mathrm{~s}$ exhibited tight surface; in some places, depressions and ridges appeared $\left(\mathrm{R}_{\mathrm{a}}=2.90 \mathrm{~nm}\right.$, $\mathrm{R}_{\mathrm{q}}=3.98 \mathrm{~nm}$ ) (Figures S37, S38 and Figure 17). These layers are slightly rougher than the deposits obtained in the spin coating process $\left(R_{a}=2.46 \mathrm{~nm}, R_{q}=2.14 \mathrm{~nm}\right)$. Reducing the immersion time to $20 \mathrm{~s}$ led to a more covered surface-the weight percent of silicon equals 10 , which suggests a relatively good deposition of the copper complex on the surface. The best dip-coating parameters were immersion rate 10, immersion speed $80 \mathrm{~mm} / \mathrm{min}$, immersion time $20 \mathrm{~s}$ (Figures S15 and S39). The EDX analysis confirmed the presence of the complex by the percentage of copper $9.93 \mathrm{wt} . \%$, oxygen $3.25 \mathrm{wt} . \%$, fluoride $55.34 \mathrm{wt} . \%$, carbon $6.29 \mathrm{wt} . \%$, and nitrogen $4.22 \mathrm{wt} . \%$. 


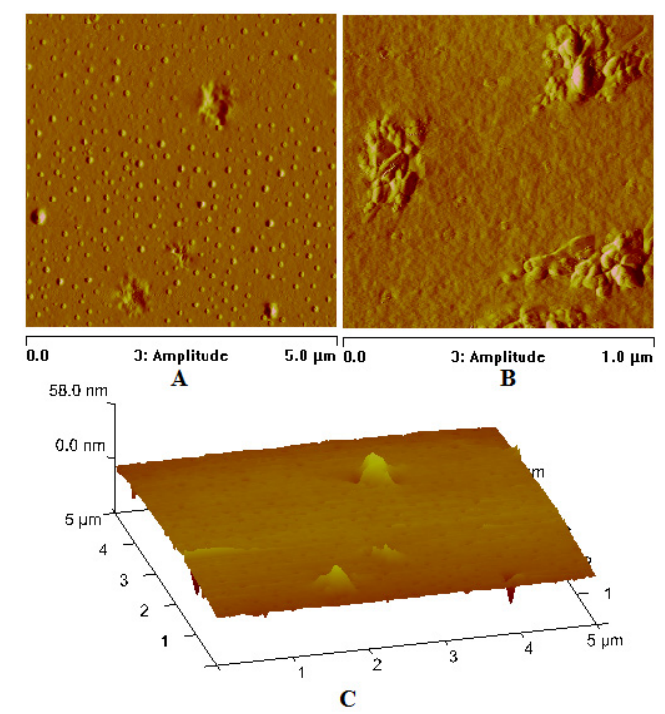

Figure 17. AFM images of $\left[\mathrm{Cu}_{2}\left(\mathrm{EtNH}_{2}\right)_{2}\left(\mu-\mathrm{O}_{2} \mathrm{CC}_{3} \mathrm{~F}_{7}\right)_{4}\right](3) / \mathrm{Si}$ immersion time $30 \mathrm{~s}$, amplitude Mag $=5 \mu \mathrm{m}(\mathbf{A}) ; \mathrm{Mag}=1 \mu \mathrm{m}(\mathbf{B})$, height $(\mathbf{C})$ before heating, dip coating, $\mathrm{R}_{\mathrm{a}}=2.90 \mathrm{~nm}, \mathrm{R}_{\mathrm{q}}=3.98 \mathrm{~nm}$.

The $\left[\mathrm{Cu}_{2}\left(\mathrm{EtNH}_{2}\right)_{2}\left(\mu-\mathrm{O}_{2} \mathrm{CC}_{2} \mathrm{~F}_{5}\right)_{4}\right]$ (2) complex forming materials obtained by deposition on $\mathrm{Si}(111)$ exhibited a thin, regular structure at the following roughness parameters as follows: $R_{a}=0.34-0.40 \mathrm{~nm}, R_{\mathrm{q}}=0.45-0.50 \mathrm{~nm}$. In some cases, small, single crystallites appeared. These layers are smoother than those fabricated by the spin-coating method $\left(R_{a}=1.78 \mathrm{~nm}, R_{q}=2.37 \mathrm{~nm}\right.$ for $\left.\mathrm{SC}\right)$. The phase AFM images show homogeneity of the covers (Figure 18). One area of the complex layer was observed. The height of the layer was equal to $68 \mathrm{~nm}$. Additionally, the AFM analysis pointed out a difference in the materials depending on the coating counts (5 or 10). In both cases, the layers are smooth, but increasing the coating count leads to the layers in which the singular, randomly distributed crystallites appear.

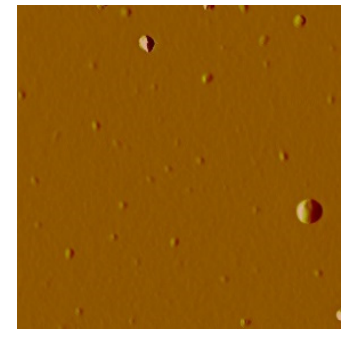

amplitude

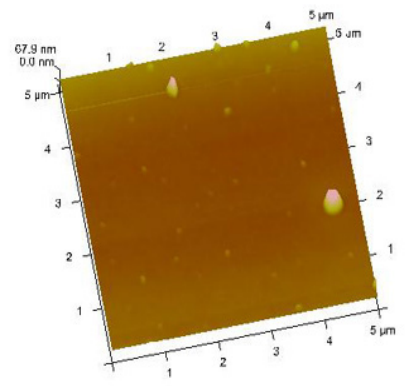

height

Figure 18. AFM images of $\left[\mathrm{Cu}_{2}\left(\mathrm{EtNH}_{2}\right)_{2}\left(\mu-\mathrm{O}_{2} \mathrm{CC}_{2} \mathrm{~F}_{5}\right)_{4}\right](2) / \mathrm{Si}$, Mag $=5 \mu \mathrm{m}$, dip coating before heating.

For all the dip-coated materials, the roughness of the layers increased after heating. The enhancement of the roughness is a consequence of the solvent lose and decomposition of the copper complex. Other authors observed the same effect in the case of silver and copper complexes $[13,14,45]$. After heating, the layers' shape, structure, and composition were changed significantly. In the $\left[\mathrm{Cu}_{2}\left(\mathrm{EtNH}_{2}\right)_{2}\left(\mu-\mathrm{O}_{2} \mathrm{CC}_{3} \mathrm{~F}_{7}\right)_{4}\right](3) / \mathrm{Si}$ materials, the grains of sizes from 5 to $500 \mathrm{~nm}$, formed irregular aggregates. The regular grains were evenly dispersed on the silicon surface (Figures S40A and 19-21). 


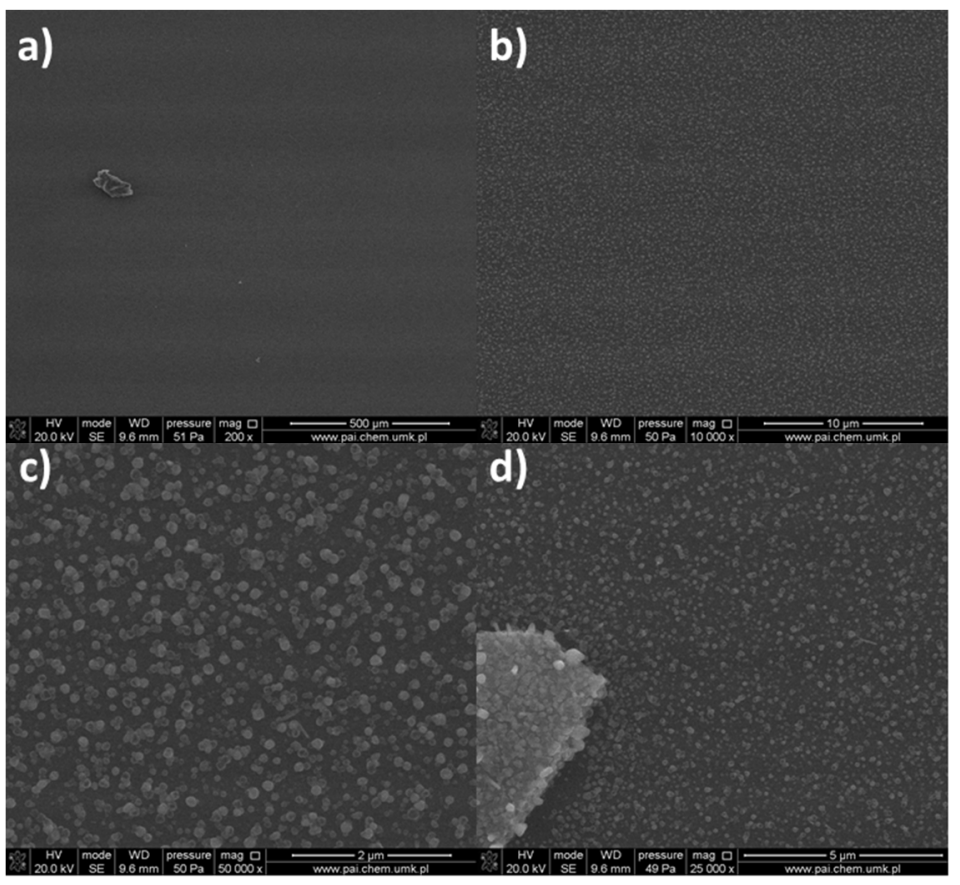

Figure 19. SEM images of $\left[\mathrm{Cu}_{2}\left(\mathrm{EtNH}_{2}\right)_{2}\left(\mu-\mathrm{O}_{2} \mathrm{CC}_{3} \mathrm{~F}_{7}\right)_{4}\right] / \mathrm{Si}(3), \mathrm{Mag}=200 \times(\mathbf{a}), \mathrm{Mag}=10,000 \times(\mathbf{b})$, Mag $=50,000 \times(\mathbf{c})$, and Mag $=25,000 \times(\mathbf{d})$, immersion time $20 \mathrm{~s}$, after heating.

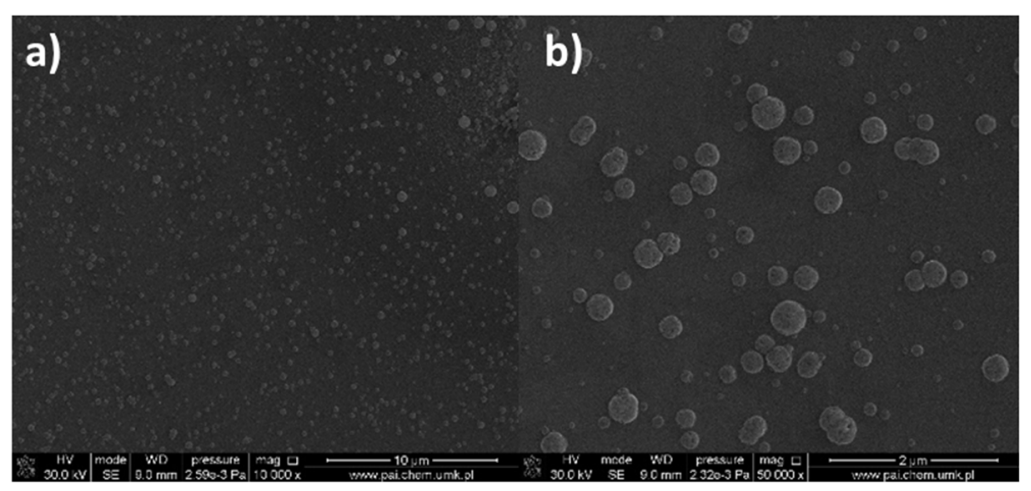

Figure 20. SEM images of $\left[\mathrm{Cu}_{2}\left(\mathrm{EtNH}_{2}\right)_{2}\left(\mu-\mathrm{O}_{2} \mathrm{CC}_{3} \mathrm{~F}_{7}\right)_{4}\right]$ (3)/Si after heating, (a) Mag = 10,000 $\times$, (b) $\mathrm{Mag}=50,000 \times$.

Surprisingly, the relative copper content decreased several times in some cases (e.g., from 9.93 to 5.64 wt.\%). The layers were smooth with $R_{a}=3.53 \mathrm{~nm}, \mathrm{R}_{\mathrm{q}}=4.31 \mathrm{~nm}$ before heating and rough $\mathrm{R}_{\mathrm{a}}=33.4 \mathrm{~nm}, \mathrm{R}_{\mathrm{q}}=42.3 \mathrm{~nm}$ after heating (Figure 21).

Similar results were observed in the case of nickel and cobalt films, which were achieved by a dip-coating process using acetolhydrazone (ALH) as a dissolving and reducing agent [46]. When the copper acetate and diethanoldiamine as solvent were used and the produced films were then heated, thin, homogenous, and smooth layers without cracks were obtained [25]. The films consisted of grains of sizes dependent on heating temperature. The roughness of these films was relatively low and ranged from 50 to $100 \mathrm{~nm}$. 

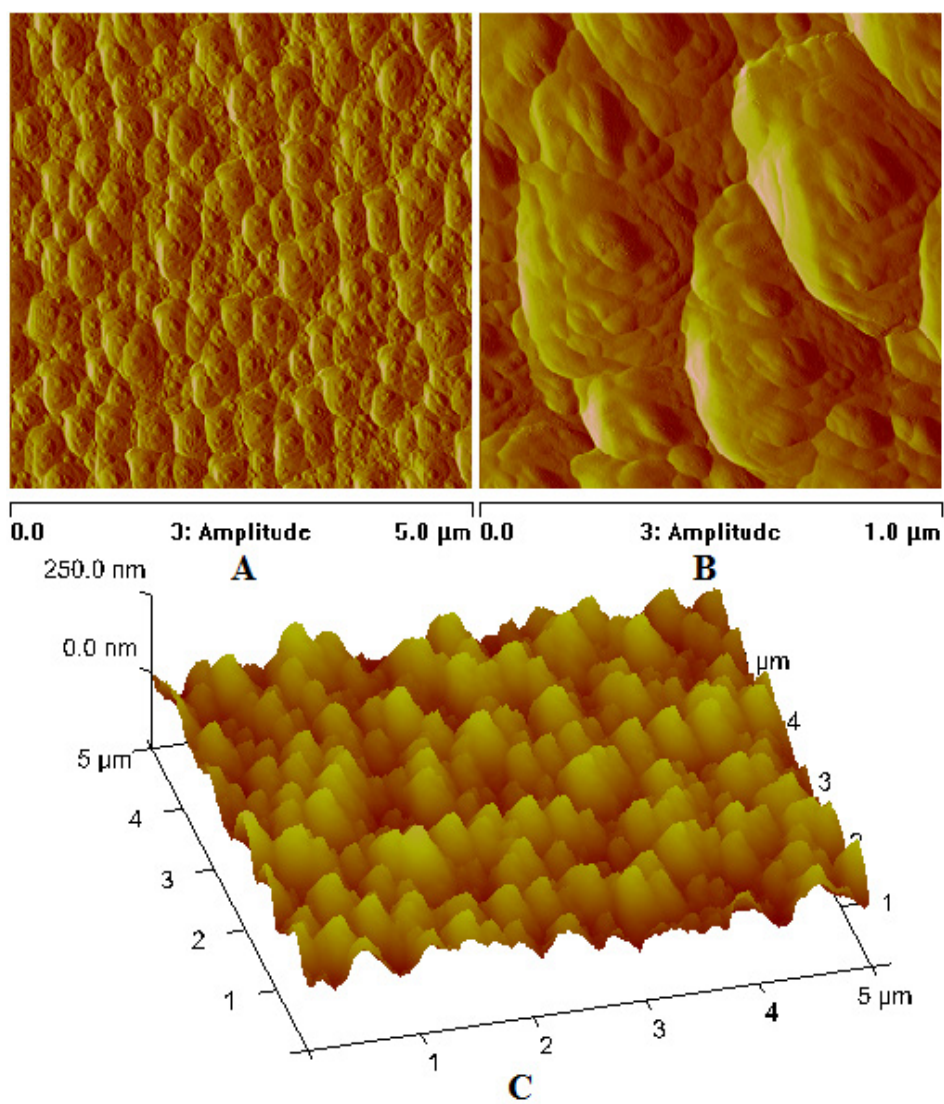

Figure 21. AFM images of $\left[\mathrm{Cu}_{2}\left(\mathrm{EtNH}_{2}\right)_{2}\left(\mu-\mathrm{O}_{2} \mathrm{CC}_{3} \mathrm{~F}_{7}\right)_{4}\right]$ (3)/Si immersion time $20 \mathrm{~s}$, Mag $5 \mu \mathrm{m}$ (A); Mag $1 \mu \mathrm{m}(\mathbf{B})$ height $(\mathbf{C})$, after heating.

Additionally, for $\left[\mathrm{Cu}_{2}\left(\mathrm{EtNH}_{2}\right)_{2}\left(\mu-\mathrm{O}_{2} \mathrm{CC}_{3} \mathrm{~F}_{7}\right)_{4}\right](3) / \mathrm{Si}$ covers after heating, TEM analysis was performed (Figure 22). TEM results confirmed the presence of copper (96.51 atomic \%) and a small amount of oxygen in the layer, suggesting the metallic copper materials as the final product of thermal treatment. The diffraction analysis pointed to the $\mathrm{d}_{\mathrm{h} \mathrm{kl}}=2 / 5 \mathrm{~nm}=0.4 \mathrm{~nm}$ and confirmed the copper grains formation as the final heating product [47]. The materials were formed by spherical structures of around $50 \mathrm{~nm}$ in size and were also grouped, creating agglomerates.

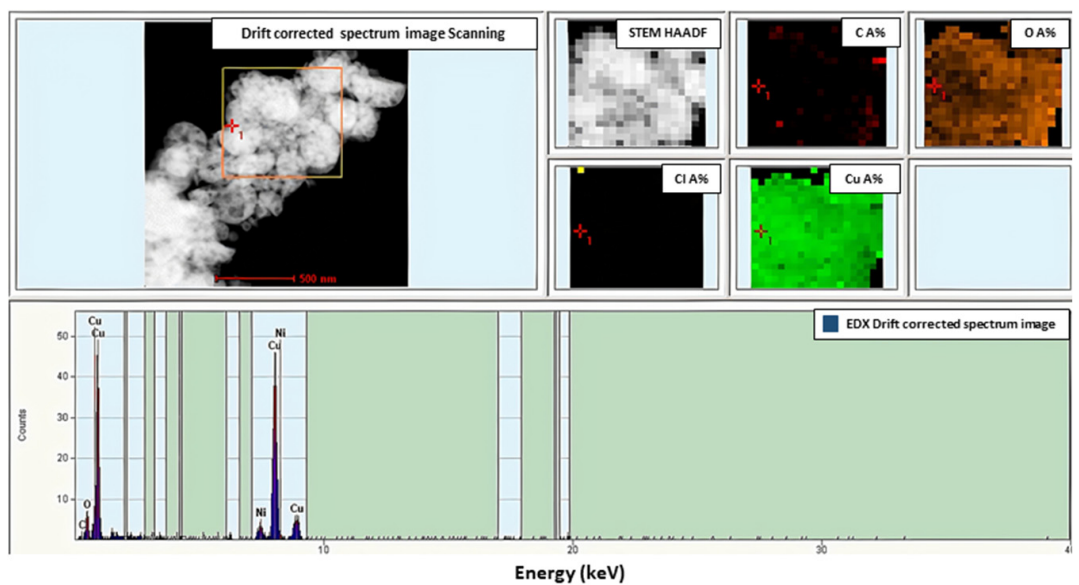

(a)

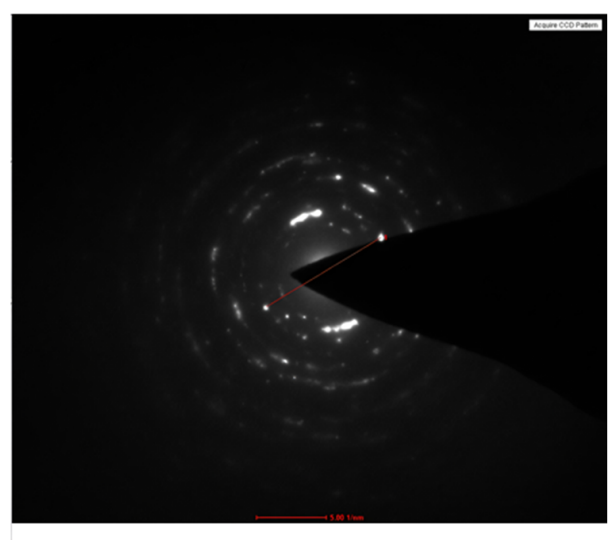

(b)

Figure 22. TEM data of the $\left[\mathrm{Cu}_{2}\left(\mathrm{EtNH}_{2}\right)_{2}\left(\mu-\mathrm{O}_{2} \mathrm{CC}_{3} \mathrm{~F}_{7}\right)_{4}\right](3) / \mathrm{Si}$ after heating, (a) TEM image (top left), chemical mapping (top right) and EDX spectrum (bottom), (b) diffraction pattern $\mathrm{d}_{\mathrm{h} \mathrm{k} 1}=2 / 5 \mathrm{~nm}=0.4 \mathrm{~nm}$. 
Moreover, for $\left[\mathrm{Cu}_{2}\left(\mathrm{EtNH}_{2}\right)_{2}\left(\mu-\mathrm{O}_{2} \mathrm{CC}_{2} \mathrm{~F}_{5}\right)_{4}\right](2) / \mathrm{Si}$, the regular spherical shapes of $7-420 \mathrm{~nm}$ in dimension were observed (Figure S40B and Figure 23). These grains were regularly disposed on the silicon surface. These structures are unusual regarding materials obtained by the dip-coating method.

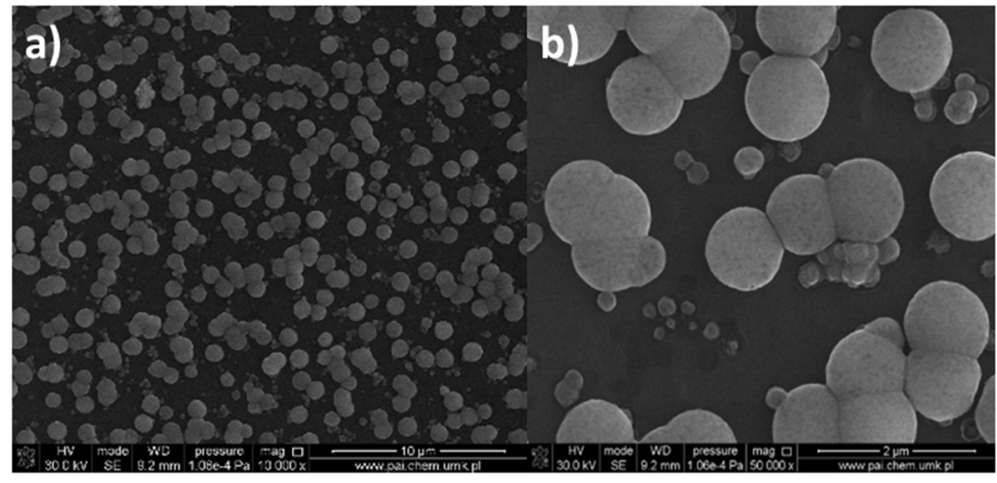

Figure 23. SEM images of $\left[\mathrm{Cu}_{2}\left(\mathrm{EtNH}_{2}\right)_{2}\left(\mu-\mathrm{O}_{2} \mathrm{CC}_{2} \mathrm{~F}_{5}\right)_{4}\right](2) / \mathrm{Si}$, after heating, (a) Mag $=10,000 \times$, (b) Mag 50,000×.

The EDX results indicated the presence of copper and oxygen suggesting copper oxide to be the thermal decomposition product. Carbon as an impurity was detected as well (a few weight percent). Grains were evenly spread on the silicon surface. Therefore, a tight, rough surface of materials without cracks was observed (Figures 24 and 25). The surface roughness increased from several to tens of nanometres $\left(R_{a}\right.$ over the range 14.0$33.0 \mathrm{~nm}, \mathrm{R}_{\mathrm{q}}=21.5-42.0 \mathrm{~nm}$ ). The height of the layer is about $0.5 \mu \mathrm{m}$. The increase in the surface's roughness was observed for materials resulting from applying both, the spin- and dip-coating methods.

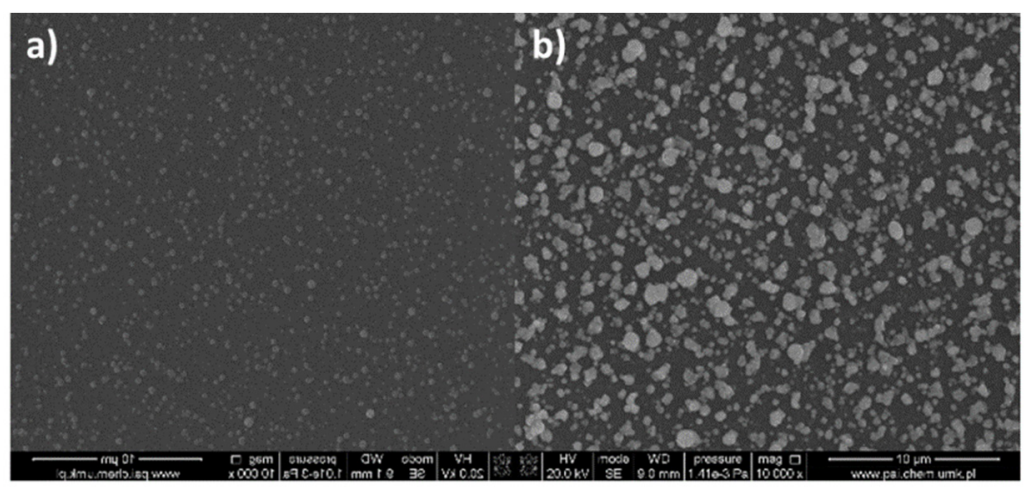

Figure 24. SEM image of $\left[\mathrm{Cu}_{2}\left(\mathrm{EtNH}_{2}\right)_{2}\left(\mu-\mathrm{O}_{2} \mathrm{CC}_{3} \mathrm{~F}_{7}\right)_{4}\right]$ (3)/Si, immersion time $20 \mathrm{~s}$, after heating, (a) the main, homogeneous cover, (b) the area at the bottom with the high deposit concentration

The comparison of the layers obtained by two different wet methods, i.e., dip- and spin- coating indicates that the better results-thin, smooth materials without cracks with high copper content- were obtained by the dip-coating technique (immersion rate: 10 or 5 , immersion speed $80 \mathrm{~mm} / \mathrm{min}$, immersion time $20 \mathrm{~s}$ ). Moreover, the best conditions for the spin-coating process were $1000 \mathrm{rpm}$ and of $30 \mathrm{~s}$ coating time. Better results were obtained for the $\left[\mathrm{Cu}_{2}\left(\mathrm{EtNH}_{2}\right)_{2}\left(\mu-\mathrm{O}_{2} \mathrm{CC}_{3} \mathrm{~F}_{7}\right)_{4}\right]$ (3) complex.

After heating, all the surfaces prepared by the spin-coating method change colour and roughness (from several to tens of nanometres). Additionally, the presence of cracks was noted. However, the films obtained by the dip-coating technique keep the tight structure, changing their colour and roughness (from several to tens of nanometres). This latter method can be an alternative to the CVD technique. 


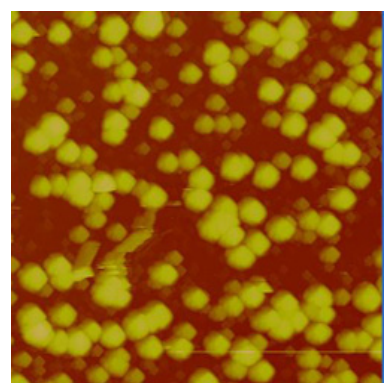

height

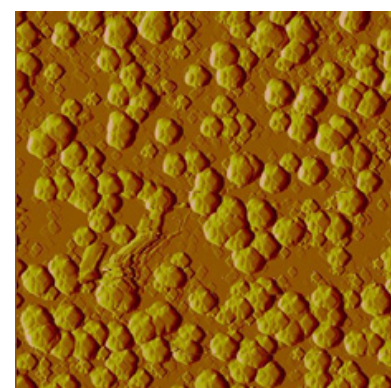

amplitude

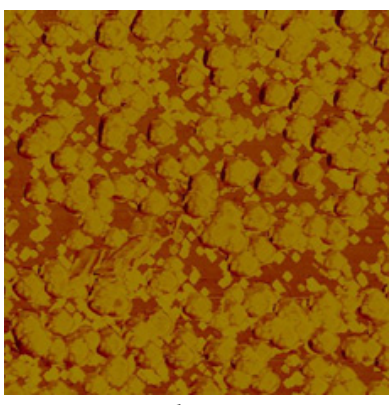

phase

Figure 25. AFM images of $\left[\mathrm{Cu}_{2}\left(\mathrm{EtNH}_{2}\right)_{2}\left(\mu-\mathrm{O}_{2} \mathrm{CC}_{3} \mathrm{~F}_{7}\right)_{4}\right](3) / \mathrm{Si}$, immersion time $20 \mathrm{~s}$. Mag $5 \mu \mathrm{m}$, after heating.

\section{Conclusions}

Copper(II) carboxylate complexes group with ethylamine and isopropylamine of the general formula $\left[\mathrm{Cu}_{2}\left(\mathrm{RNH}_{2}\right)_{2}\left(\mu-\mathrm{O}_{2} \mathrm{CR}_{\mathrm{f}}\right)_{4}\right](\mathbf{1}-\mathbf{1 0})$, where $\mathrm{R}=\mathrm{Et},{ }^{\mathrm{i}} \mathrm{Pr}, \mathrm{R}_{\mathrm{f}}=\mathrm{C}_{\mathrm{n}} \mathrm{F}_{2 \mathrm{n}+1}, \mathrm{n}=1-6$, were synthesized in the reaction of copper(II) perfluorinated carboxylates with amines in situ generated from ethyl or isopropyl isocyanate. These compounds form blue gel-like solids. Based on the IR spectra analysis, the carboxylates bridging coordination mode and the axially N-bonded amine molecules were proposed, which results in the $\mathrm{CuNO}_{4}$ coordination sphere and the dimeric structure of the compounds in the solid state. The electron impact mass spectra analysis exhibited the occurrence of metallated species in the gas phase. The registered pseudomolecular ions $\left[\mathrm{Cu}_{2}\left(\mathrm{EtNH}_{2}\right)_{2}\left(\mu-\mathrm{O}_{2} \mathrm{CR}_{\mathrm{f}}\right)_{3}\right]^{+}$and $\left[\mathrm{Cu}_{2}\left({ }^{\mathrm{i}} \mathrm{PrNH}_{2}\right)_{2}(\mu-\right.$ $\left.\left.\mathrm{O}_{2} \mathrm{CR}_{\mathrm{f}}\right)_{3}\right]^{+}$confirmed the above proposed dimeric structure for the studied complexes both in the solid-state and in the gas phase. The thermal analysis showed that copper transfer to the gas phase took place at atmospheric pressure for complexes $\left[\mathrm{Cu}_{2}\left(\mathrm{EtNH}_{2}\right)_{2}(\mu-\right.$ $\left.\left.\mathrm{O}_{2} \mathrm{CC}_{3} \mathrm{~F}_{7}\right)_{4}\right](3),\left[\mathrm{Cu}_{2}\left(\mathrm{EtNH}_{2}\right)_{2}\left(\mu-\mathrm{O}_{2} \mathrm{CC}_{4} \mathrm{~F}_{9}\right)_{4}\right](4),\left[\mathrm{Cu}_{2}\left({ }^{\mathrm{i}} \mathrm{PrNH}_{2}\right)_{2}\left(\mu-\mathrm{O}_{2} \mathrm{CC}_{2} \mathrm{~F}_{5}\right)_{4}\right](8)$, and $\left[\mathrm{Cu}_{2}\left({ }^{\mathrm{i}} \mathrm{PrNH}_{2}\right)_{2}\left(\mu-\mathrm{O}_{2} \mathrm{CC}_{3} \mathrm{~F}_{7}\right)_{4}\right](9)$. In VT IR spectra, vapours of the (1) and (4) complexes vapours were observed over the temperature range $433-533 \mathrm{~K}$, but in the case of the (2) compound-from 463 to $513 \mathrm{~K}$. For the compounds containing isopropyl group bands, vapours of the corresponding complexes were noticed over 493-533 K (7) and 473-613 K (8). Therefore, the complexes with ethylamine require a lower evaporation temperature than precursors with isopropylamine.

The CVD experiments confirmed that the $\left[\mathrm{Cu}_{2}\left(\mathrm{RNH}_{2}\right)_{2}\left(\mu-\mathrm{O}_{2} \mathrm{CR}_{\mathrm{f}}\right)_{4}\right]$ compounds are the source of metal carriers in the gas phase. The best-quality deposits consisting of pure copper were obtained using precursors $\left[\mathrm{Cu}_{2}\left(\mathrm{EtNH}_{2}\right)_{2}\left(\mu-\mathrm{O}_{2} \mathrm{CC}_{2} \mathrm{~F}_{5}\right)_{4}\right](2)$ and $\left[\mathrm{Cu}_{2}\left({ }^{\mathrm{i}} \mathrm{PrNH}_{2}\right)_{2}\right.$ $\left.\left(\mu-\mathrm{O}_{2} \mathrm{CC}_{2} \mathrm{~F}_{5}\right)_{4}\right](8)$, the evaporation temperature of $473 \mathrm{~K}$, and the deposition temperature of $713 \mathrm{~K}$. Nanorods, nanoparticles, and densely packed grains are produced from the synthesised precursors in the CVD process. The great advantage of the $\left[\mathrm{Cu}_{2}\left(\mathrm{RNH}_{2}\right)_{2}(\mu-\right.$ $\left.\left.\mathrm{O}_{2} \mathrm{CR}_{\mathrm{f}}\right)_{4}\right]$ compounds is that a metallic film can be obtained from the air-stable copper(II) compound with no need to use any additional reducing agent such as $\mathrm{H}_{2}$.

The procedure of the $\left[\mathrm{Cu}_{2}\left(\mathrm{EtNH}_{2}\right)_{2}\left(\mu-\mathrm{O}_{2} \mathrm{CR}_{\mathrm{f}}\right)_{4}\right]$ complex layer formation was not as complicated as that for copper acetate described in the literature. The use of dip- and spincoating indicates that better results, i.e., the thin, smooth materials without cracks, with a high copper content, can be obtained by dip-coating technique. The best conditions for the spin coating process were $1000 \mathrm{rpm}$ and $30 \mathrm{~s}$ coating time. The dip-coating parameters (for the $\left[\mathrm{Cu}_{2}\left(\mathrm{EtNH}_{2}\right)_{2}\left(\mu-\mathrm{O}_{2} \mathrm{CC}_{3} \mathrm{~F}_{7}\right)_{4}\right]$ complex (3)) were as follows: immersion rate 10, immersion speed $80 \mathrm{~mm} / \mathrm{min}$, and immersion time $20 \mathrm{~s}$. Heating the materials resulting from the dip- and spin-coating processes lead to thin copper metallic or copper oxide materials. In the case of the dip-coating method, spherical structures on the substrate surface were formed.

The presented results of EI MS, TG-IR, and VT IR studies confirmed the applicability of the proposed methodology for the CVD precursors selection. The thermal analysis for 
the temperature determination for the spin- and dip-coating materials heating was also proven.

Supplementary Materials: The following are available online at https://www.mdpi.com/article/ $10.3390 / \mathrm{ma1} 14237451 / \mathrm{s} 1$, Table S1 Mass spectrometry EI MS data of $\left[\mathrm{Cu}_{2}\left(\mathrm{EtNH}_{2}\right)_{2}\left(\mu-\mathrm{O}_{2} \mathrm{CC}_{2} \mathrm{~F}_{5}\right)_{4}\right]$ (2); Table S2 Mass spectrometry EI MS data of $\left[\mathrm{Cu}_{2}\left(\mathrm{EtNH}_{2}\right)_{2}\left(\mu-\mathrm{O}_{2} \mathrm{CC}_{3} \mathrm{~F}_{7}\right)_{4}\right]$ (3); Table S3 Mass spectrometry EI MS data of $\left[\mathrm{Cu}_{2}\left(\mathrm{EtNH}_{2}\right)_{2}\left(\mu-\mathrm{O}_{2} \mathrm{CC}_{4} \mathrm{~F}_{9}\right)_{4}\right](4)$; Table S4 Mass spectrometry EI MS data of $\left[\mathrm{Cu}_{2}\left(\mathrm{EtNH}_{2}\right)_{2}\left(\mu-\mathrm{O}_{2} \mathrm{CC}_{5} \mathrm{~F}_{11}\right)_{4}\right]$ (5); Table S5 Mass spectrometry EI MS data of $\left[\mathrm{Cu}_{2}\left(\mathrm{EtNH}_{2}\right)_{2}(\mu-\right.$ $\left.\left.\mathrm{O}_{2} \mathrm{CC}_{6} \mathrm{~F}_{13}\right)_{4}\right](6)$; Table S6 Mass spectrometry EI MS data of $\left[\mathrm{Cu}_{2}\left({ }^{\mathrm{i}} \mathrm{PrNH}_{2}\right)_{2}\left(\mu-\mathrm{O}_{2} \mathrm{CC}_{2} \mathrm{~F}_{5}\right)_{4}\right](8)$; Table S7 Mass spectrometry EI MS data of $\left[\mathrm{Cu}_{2}\left({ }^{\mathrm{i}} \mathrm{PrNH}_{2}\right)_{2}\left(\mu-\mathrm{O}_{2} \mathrm{CC}_{3} \mathrm{~F}_{7}\right)_{4}\right]$ (9); Table S8 Mass spectrometry EI MS data of $\left[\mathrm{Cu}_{2}\left({ }^{\mathrm{i}} \mathrm{PrNH}_{2}\right)_{2}\left(\mu-\mathrm{O}_{2} \mathrm{CC}_{4} \mathrm{~F}_{9}\right)_{4}\right]$ (10); Figure $\mathrm{S} 1$ Infrared spectrum (thin film on $\mathrm{KBr}$ plates) of $\left[\mathrm{Cu}_{2}\left(\mathrm{EtNH}_{2}\right)_{2}\left(\mu-\mathrm{O}_{2} \mathrm{CCF}_{3}\right)_{4}\right]$ (1); Figure $\mathrm{S} 2$ Infrared spectrum (thin film on KBr plates) of $\left[\mathrm{Cu}_{2}\left(\mathrm{EtNH}_{2}\right)_{2}\left(\mu-\mathrm{O}_{2} \mathrm{CC}_{2} \mathrm{~F}_{5}\right)_{4}\right](2)$; Figure $\mathrm{S} 3$ Infrared spectrum (thin film on $\mathrm{KBr}$ plates) of $\left[\mathrm{Cu}_{2}\left(\mathrm{EtNH}_{2}\right)_{2}\right.$ $\left.\left(\mu-\mathrm{O}_{2} \mathrm{CC}_{3} \mathrm{~F}_{7}\right)_{4}\right]$ (3); Figure S4 Infrared spectrum (thin film on $\mathrm{KBr}$ plates) of $\left[\mathrm{Cu}_{2}\left(\mathrm{EtNH}_{2}\right)_{2}(\mu-\right.$ $\left.\left.\mathrm{O}_{2} \mathrm{CC}_{4} \mathrm{~F}_{9}\right)_{4}\right]$ (4); Figure S5 Infrared spectrum (thin film on $\mathrm{KBr}$ plates) of $\left[\mathrm{Cu}_{2}\left(\mathrm{EtNH}_{2}\right)_{2}\left(\mu-\mathrm{O}_{2} \mathrm{CC}_{5} \mathrm{~F}_{11}\right)_{4}\right]$ (5); Figure $\mathrm{S} 6$ Infrared spectrum (thin film on $\mathrm{KBr}$ plates) of $\left[\mathrm{Cu}_{2}\left(\mathrm{EtNH}_{2}\right)_{2}\left(\mu-\mathrm{O}_{2} \mathrm{CC}_{6} \mathrm{~F}_{13}\right)_{4}\right]$ (6); Figure S7 ATR-IR spectrum of $\left[\mathrm{Cu}_{2}\left({ }^{\mathrm{i}} \mathrm{PrNH}_{2}\right)_{2}\left(\mu-\mathrm{O}_{2} \mathrm{CCF}_{3}\right)_{4}\right]$ (7); Figure S8 ATR-IR spectrum of $\left[\mathrm{Cu}_{2}\left({ }^{\mathrm{i}} \mathrm{PrNH}_{2}\right)_{2}\left(\mu-\mathrm{O}_{2} \mathrm{CC}_{2} \mathrm{~F}_{5}\right)_{4}\right]$ (8); Figure S9 ATR-IR spectra of $\left[\mathrm{Cu}_{2}\left({ }^{\mathrm{i}} \mathrm{PrNH}_{2}\right)_{2}\left(\mu-\mathrm{O}_{2} \mathrm{CC}_{3} \mathrm{~F}_{7}\right)_{4}\right](9)$; Figure S10 ATR-IR spectrum of $\left[\mathrm{Cu}_{2}\left({ }^{\mathrm{i}} \mathrm{PrNH}_{2}\right)_{2}\left(\mu-\mathrm{O}_{2} \mathrm{CC}_{3} \mathrm{~F}_{7}\right)_{4}\right]$ (10); Figure S11 Mass spectrometry EI MS spectra of $\left[\mathrm{Cu}_{2}\left(\mathrm{EtNH}_{2}\right)_{2}\left(\mu-\mathrm{O}_{2} \mathrm{CCF}_{3}\right)_{4}\right]$ (1) at temperature: (a) $305 \mathrm{~K}$, (b) $355 \mathrm{~K}$, (c) $600 \mathrm{~K}$ and (d) simulation of isotopic pattern for a pseudomolecular ion $\left[\mathrm{Cu}_{2}\left(\mathrm{EtNH}_{2}\right)_{2}\left(\mathrm{O}_{2} \mathrm{CCF}_{3}\right)_{3}\right]^{+}$; Figure S12 Mass spectrometry EI MS spectra of $\left[\mathrm{Cu}_{2}\left(\mathrm{EtNH}_{2}\right)_{2}\left(\mu-\mathrm{O}_{2} \mathrm{CC}_{2} \mathrm{~F}_{5}\right)_{4}\right]$ (2) at temperature: (a) $310 \mathrm{~K}$, (b) $331 \mathrm{~K}$, (c) $357 \mathrm{~K}$ (d) $542 \mathrm{~K}$ and (e) simulation of isotopic pattern for a pseudomolecular ion $\left[\mathrm{Cu}_{2}\left(\mathrm{EtNH}_{2}\right)_{2}\left(\mathrm{O}_{2} \mathrm{CC}_{2} \mathrm{~F}_{5}\right)_{3}\right]^{+}$; Figure $\mathrm{S} 13$ Mass spectrometry EI MS spectra of $\left[\mathrm{Cu}_{2}\left(\mathrm{EtNH}_{2}\right)_{2}(\mu-\right.$ $\left.\mathrm{O}_{2} \mathrm{CC}_{3} \mathrm{~F}_{7}\right)_{4}$ ] (3) at temperature: (a) $357 \mathrm{~K}$, (b) $417 \mathrm{~K}$, (c) $463 \mathrm{~K}$ (d) $542 \mathrm{~K}$ and (e) simulation of isotopic pattern for a pseudomolecular ion $\left[\mathrm{Cu}_{2}\left(\mathrm{EtNH}_{2}\right)_{2}\left(\mathrm{O}_{2} \mathrm{CC}_{3} \mathrm{~F}_{7}\right)_{3}\right]^{+}$; Figure S14 Mass spectrometry EI MS spectra of $\left[\mathrm{Cu}_{2}\left(\mathrm{EtNH}_{2}\right)_{2}\left(\mu-\mathrm{O}_{2} \mathrm{CC}_{4} \mathrm{~F}_{9}\right)_{4}\right]$ (4) at temperature: (a) $305 \mathrm{~K}$, (b) $345 \mathrm{~K}$, (c) $424 \mathrm{~K}$ (d) $590 \mathrm{~K}$ and (e) simulation of isotopic pattern for a pseudomolecular ion $\left[\mathrm{Cu}_{2}\left(\mathrm{EtNH}_{2}\right)_{2}\left(\mathrm{O}_{2} \mathrm{CC}_{4} \mathrm{~F}_{9}\right)_{3}\right]^{+}$; Figure S15 Mass spectrometry EI MS spectra of $\left[\mathrm{Cu}_{2}\left(\mathrm{EtNH}_{2}\right)_{2}\left(\mu-\mathrm{O}_{2} \mathrm{CC}_{5} \mathrm{~F}_{11}\right)_{4}\right]$ (5) at temperature: (a) $319 \mathrm{~K}$, (b) $425 \mathrm{~K}$, (c) $590 \mathrm{~K}$ and (d) simulation of isotopic pattern for a pseudomolecular ion $\left[\mathrm{Cu}_{2}\left(\mathrm{EtNH}_{2}\right)_{2}\left(\mathrm{O}_{2} \mathrm{CC}_{5} \mathrm{~F}_{11}\right)_{3}\right]^{+}$; Figure S16 Mass spectrometry EI MS spectra of $\left[\mathrm{Cu}_{2}\left(\mathrm{EtNH}_{2}\right)_{2}(\mu-\right.$ $\left.\mathrm{O}_{2} \mathrm{CC}_{6} \mathrm{~F}_{13}\right)_{4}$ ] (6) at temperature: (a) $305 \mathrm{~K}$, (b) $398 \mathrm{~K}$, (c) $431 \mathrm{~K}$ (d) $616 \mathrm{~K}$ and (e) simulation of isotopic pattern for a pseudomolecular ion $\left[\mathrm{Cu}_{2}\left(\mathrm{EtNH}_{2}\right)_{2}\left(\mathrm{O}_{2} \mathrm{CC}_{6} \mathrm{~F}_{13}\right)_{3}\right]^{+}$; Figure $\mathrm{S} 17$ Mass spectrometry EI MS spectra of $\left[\mathrm{Cu}_{2}\left({ }^{\mathrm{i}} \mathrm{PrNH}_{2}\right)_{2}\left(\mu-\mathrm{O}_{2} \mathrm{CCF}_{3}\right)_{4}\right]$ (7) at temperature: (a) $368 \mathrm{~K}$, (b) $389 \mathrm{~K}$, (c) 548 and (d) simulation of isotopic pattern for a pseudomolecular ion $\left[\mathrm{Cu}_{2}\left({ }^{\mathrm{i}} \mathrm{PrNH}_{2}\right)_{2}\left(\mathrm{O}_{2} \mathrm{CCF}_{3}\right)_{3}\right]^{+}$; Figure S18 Mass spectrometry EI MS spectra of $\left[\mathrm{Cu}_{2}\left({ }^{i} \mathrm{PrNH}_{2}\right)_{2}\left(\mu-\mathrm{O}_{2} \mathrm{CC}_{2} \mathrm{~F}_{5}\right)_{4}\right]$ (8) at temperature: (a) $357 \mathrm{~K}$, (b) $404 \mathrm{~K}$, (c) $458 \mathrm{~K}$, (d) $505 \mathrm{~K}$ and (e) simulation of isotopic pattern for a pseudomolecular ion $\left[\mathrm{Cu}_{2}\left({ }^{\mathrm{i}} \mathrm{PrNH}_{2}\right)_{2}\left(\mathrm{O}_{2} \mathrm{CC}_{2} \mathrm{~F}_{5}\right)_{3}\right]^{+}$; Figure $\mathrm{S} 19$ Mass spectrometry EI MS spectra of $\left[\mathrm{Cu}_{2}\left({ }^{\mathrm{i}} \mathrm{PrNH}_{2}\right)_{2}(\mu-\right.$ $\left.\mathrm{O}_{2} \mathrm{CC}_{3} \mathrm{~F}_{7}\right)_{4}$ ] (9) at temperature: (a) $340 \mathrm{~K}$, (b) $372 \mathrm{~K}$, (c) $499 \mathrm{~K}$, (d) $544 \mathrm{~K}$ and (e) simulation of isotopic pattern for a pseudomolecular ion $\left[\mathrm{Cu}_{2}\left({ }^{\mathrm{i}} \mathrm{PrNH}_{2}\right)_{2}\left(\mathrm{O}_{2} \mathrm{CC}_{3} \mathrm{~F}_{7}\right)_{3}\right]^{+} ;$Figure S20 Mass spectrometry EI MS spectra of $\left[\mathrm{Cu}_{2}\left({ }^{\mathrm{i}} \mathrm{PrNH}_{2}\right)_{2}\left(\mu-\mathrm{O}_{2} \mathrm{CC}_{4} \mathrm{~F}_{9}\right)_{4}\right]$ (10) (a) $369 \mathrm{~K}$, (b) $388 \mathrm{~K}$, (c) $401 \mathrm{~K}$, (d) $490 \mathrm{~K}$ and (e) simulation of isotopic pattern for a pseudomolecular ion $\left[\mathrm{Cu}_{2}\left({ }^{(} \mathrm{PrNH}_{2}\right)_{2}\left(\mathrm{O}_{2} \mathrm{CC}_{4} \mathrm{~F}_{9}\right)_{3}\right]^{+}$; Figure S21 Thermal decomposition of $\left[\mathrm{Cu}_{2}\left(\mathrm{EtNH}_{2}\right)_{2}\left(\mu-\mathrm{O}_{2} \mathrm{CCF}_{3}\right)_{4}\right]$ (1) (TG, DTG, DTA curves); Figure S22 TGA/IR spectrum of $\left[\mathrm{Cu}_{2}\left(\mathrm{EtNH}_{2}\right)_{2}\left(\mu-\mathrm{O}_{2} \mathrm{CCF}_{3}\right)_{4}\right]$ (1) registered at temperature $423 \mathrm{~K}$; Figure $\mathrm{S} 23$ Thermal decomposition of $\left[\mathrm{Cu}_{2}\left(\mathrm{EtNH}_{2}\right)_{2}\left(\mu-\mathrm{O}_{2} \mathrm{CC}_{3} \mathrm{~F}_{7}\right)_{4}\right]$ (3) (TG, DTG, DTA curves); Figure S24 Thermal decomposition of $\left[\mathrm{Cu}_{2}\left(\mathrm{EtNH}_{2}\right)_{2}\left(\mu-\mathrm{O}_{2} \mathrm{CC}_{4} \mathrm{~F}_{9}\right)_{4}\right]$ (4) (TG, DTG, DTA curves); Figure S25 Thermal decomposition of $\left[\mathrm{Cu}_{2}\left({ }^{\mathrm{i}} \mathrm{PrNH}_{2}\right)_{2}\left(\mu-\mathrm{O}_{2} \mathrm{CCF}_{3}\right)_{4}\right]$ (7); Figure S26 Thermal decomposition of $\left[\mathrm{Cu}_{2}\left({ }^{\mathrm{i}} \mathrm{PrNH}_{2}\right)_{2}\left(\mu-\mathrm{O}_{2} \mathrm{CC}_{2} \mathrm{~F}_{5}\right)_{4}\right]$ (8); Figure S27 Thermal decomposition of $\left[\mathrm{Cu}_{2}\left({ }^{\mathrm{i}} \mathrm{PrNH}_{2}\right)_{2}\left(\mu-\mathrm{O}_{2} \mathrm{CC}_{3} \mathrm{~F}_{7}\right)_{4}\right]$ (9); Figure S28 Thermal decomposition of $\left[\mathrm{Cu}_{2}\left({ }^{\mathrm{i}} \mathrm{PrNH}_{2}\right)_{2}\left(\mu-\mathrm{O}_{2} \mathrm{CC}_{3} \mathrm{~F}_{7}\right)_{4}\right](10)$; Figure $\mathrm{S} 29$ Temperature variable infrared spectra VT IR of vapors formed during the $\left[\mathrm{Cu}_{2}\left(\mu-\mathrm{O}_{2} \mathrm{CC}_{2} \mathrm{~F}_{5}\right)_{4}\right]$ heating; Figure S30 Infrared spectra for the $\left[\mathrm{Cu}_{2}\left(\mu-\mathrm{O}_{2} \mathrm{CCF}_{3}\right)_{4}\right]$ in the solid state; Figure $\mathrm{S} 31$ Temperature variable infrared spectra VT IR of vapors formed during the $\left[\mathrm{Cu}_{2}\left(\mathrm{EtNH}_{2}\right)_{2}\left(\mu-\mathrm{O}_{2} \mathrm{CC}_{2} \mathrm{~F}_{5}\right)_{4}\right]$ complex (2) heating; Figure S32 The spectra comparison for the $\left[\mathrm{Cu}_{2}\left(\mathrm{EtNH}_{2}\right)_{2}\left(\mu \mathrm{O}_{2} \mathrm{CC}_{2} \mathrm{~F}_{5}\right)_{4}\right]$ complex (2) in the solid state (orange line) and in the gas phase at $473 \mathrm{~K}$ (blue line); Figure S33 Temperature variable infrared spectra VT IR of vapors formed during the $\left[\mathrm{Cu}_{2}\left(\mathrm{EtNH}_{2}\right)_{2}\left(\mu-\mathrm{O}_{2} \mathrm{CC}_{4} \mathrm{~F}_{9}\right)_{4}\right]$ complex (4) heating; Figure S34 The spectra comparison for the $\left[\mathrm{Cu}_{2}\left(\mathrm{EtNH}_{2}\right)_{2}\left(\mu_{2} \mathrm{CC}_{4} \mathrm{~F}_{9}\right)_{4}\right]$ complex (4) a) in the solid state (red line) and in the gas phase at $493 \mathrm{~K}$ (black line) b) at temperature $493 \mathrm{~K}$ and $533 \mathrm{~K}$; Figure S35 Temperature vari- 
able infrared spectra VT IR for the vapor formed during the $\left[\mathrm{Cu}_{2}\left({ }^{\mathrm{i}} \mathrm{PrNH}_{2}\right)_{2}\left(\mu-\mathrm{O}_{2} \mathrm{CCF}_{3}\right)_{4}\right]$ complex (7) heating; Figure S36 Temperature variable infrared spectra VT IR of vapors formed during the $\left[\mathrm{Cu}_{2}\left({ }^{\mathrm{i}} \mathrm{PrNH}_{2}\right)_{2}\left(\mu-\mathrm{O}_{2} \mathrm{CC}_{2} \mathrm{~F}_{5}\right)_{4}\right]$ complex (8) heating 433-733K and at temperature $493 \mathrm{~K}$ (red line); Figure S37 Optical microscope images of $\left[\mathrm{Cu}_{2}\left(\mathrm{EtNH}_{2}\right)_{2}\left(\mu-\mathrm{O}_{2} \mathrm{CC}_{3} \mathrm{~F}_{7}\right)_{4}\right](3) / \mathrm{Si}$ before heating, immersion time 30, before heating (A) the immersion line, (B) middle of the layer; Figure S38 SEM image of $\left[\mathrm{Cu}_{2}\left(\mathrm{EtNH}_{2}\right)_{2}\left(\mu-\mathrm{O}_{2} \mathrm{CC}_{3} \mathrm{~F}_{7}\right)_{4}\right](3) / \mathrm{Si}$ immersion time 30, Mag = 200x, before heating; Figure S39 Optical microscope images of $\left[\mathrm{Cu}_{2}\left(\mathrm{EtNH}_{2}\right)_{2}\left(\mu-\mathrm{O}_{2} \mathrm{CC}_{3} \mathrm{~F}_{7}\right)_{4}\right](3) / \mathrm{Si}$, before heating, immersion time 20 , coating count 10 , Mag $5 x$, lower part of the substrate $(\mathrm{A})$, middle of the layer (B), immersion line (C); Figure S40 Images from optical microscope after heating (A) $\left[\mathrm{Cu}_{2}\left(\mathrm{EtNH}_{2}\right)_{2}\left(\mu-\mathrm{O}_{2} \mathrm{CC}_{3} \mathrm{~F}_{7}\right)_{4}\right](3) / \mathrm{Si}$ immersion time 20; (B) $\left[\mathrm{Cu}_{2}\left(\mathrm{EtNH}_{2}\right)_{2}\left(\mu-\mathrm{O}_{2} \mathrm{CC}_{2} \mathrm{~F}_{5}\right)_{4}\right](2) / \mathrm{Si}$ immersion time 20.

Author Contributions: Conceptualization, M.B. and I.B.S.; investigation, A.B., K.M., M.B. and I.B.S.; writing-original draft preparation, A.B., K.M., M.B. and I.B.S.; writing-review and editing, A.B., K.M., M.B. and I.B.S.; visualization, A.B. and K.M.; supervision, M.B. and I.B.S.; funding acquisition, I.B.S. All authors have read and agreed to the published version of the manuscript.

Funding: The financing of this work was by National Science Centre (grant: N N204 546539) and Nicolaus Copernicus University in Torun (PDB no. 103).

Institutional Review Board Statement: Not applicable.

Informed Consent Statement: Not applicable.

Data Availability Statement: The data presented in this study are available on request from the corresponding author.

Conflicts of Interest: The authors declare no conflict of interest.

\section{References}

1. Padnya, P.; Shibaeva, K.; Arsenyev, M.; Baryshnikova, S.; Terenteva, O.; Shiabiev, I.; Khannanov, A.; Boldyrev, A.; Gerasimov, A.; Grishaev, D.; et al. Catechol-Containing Schiff Bases on Thiacalixarene: Synthesis, Copper (II) Recognition, and Formation of Organic-Inorganic Copper-Based Materials. Molecules 2021, 26, 2334. [CrossRef]

2. Hao, X.-L.; Ma, Y.-Y.; Zhang, C.; Wang, Q.; Cheng, X.; Wang, Y.-H.; Li, Y.-G.; Wang, E.-B. Assembly of new organic-inorganic hybrids based on copper-bis(triazole) complexes and Keggin-type polyoxometalates with different negative charges. CrystEngComm 2012, 14, 6573-6580. [CrossRef]

3. Wang, L.; Sun, H.; Sun, C.; Xu, D.; Tao, J.; Wei, T.; Zhang, Z.; Zhang, Y.; Wang, Z.; Bi, W. Lead-free, stable orange-red-emitting hybrid copper based organic-inorganic compounds. Dalton Trans. 2021, 50, 2766-2773. [CrossRef] [PubMed]

4. Li, X.; Zhong, X.; Hu, Y.; Li, B.; Sheng, Y.; Zhang, Y.; Weng, C.; Feng, M.; Han, H.; Wang, J. Organic-Inorganic Copper(II)-Based Material: A Low-Toxic, Highly Stable Light Absorber for Photovoltaic Application. J. Phys. Chem. Lett. 2017, 8, 1804-1809. [CrossRef] [PubMed]

5. Srivastava, P.C.; Singh, B.N.; Adhya, S.D.; Banerji, K.C. Thermal behaviour of copper oxalate and its mixed ligand complexes with amines. J. Therm. Anal. 1983, 27, 263-273. [CrossRef]

6. Perova, E.V.; Yakovleva, M.A.; Baranova, E.O.; Anan'ev, I.V.; Nefedov, S.E. Reactions of aqueous copper acetate with triethylamine and 3,5-dimethylpyrazole. Russ. J. Inorg. Chem. 2010, 55, 714-726. [CrossRef]

7. Rigamonti, L.; Carlino, S.; Halibi, Y.; Demartin, F.; Castellano, C.; Ponti, A.; Pievo, R.; Pasini, A. Copper 1D coordination polymers and dimers: Role of the carboxylate and the ammonium cation, crystal structures and magnetic studies. Polyhedron 2013, 53, 157-165. [CrossRef]

8. Kumar, N.; Kalsotra, B.L. Preparation of Complexes of Copper(II) Aryl Carboxylates with Diethyl Amine and Dipropyl Amine. J. Chin. Chem. Soc. 1974, 21, 267-269. [CrossRef]

9. Szymańska, I.B. Gaseous phase studies of new copper(II) carboxylate complexes with tert-butylamine as potential precursors for chemical vapor deposition (CVD). Polyhedron 2013, 50, 200-207. [CrossRef]

10. Piszczek, P.; Szymańska, I.B.; Talik, E.; Heimann, J. Deposition of thin copper layers using copper(II) carboxylate complexes with tert-butylamine as new CVD precursors. Chem. Vap. Depos. 2013, 19, 251-259. [CrossRef]

11. Lacko, M.; Papp, P.; Szymańska, I.B.; Szłyk, E.; Matejčík, Š. Electron interaction with copper(II) carboxylate compounds. Beilstein J. Nanotechnol. 2018, 9, 384-398. [CrossRef] [PubMed]

12. Sala, L.; Szymańska, I.B.; Dablemont, C.; Lafosse, A.; Amiaud, L. Response under low-energy electron irradiation of a thin film of a potential copper precursor for focused electron beam induced deposition (FEBID). Beilstein J. Nanotechnol. 2018, 9, 57-65. [CrossRef] [PubMed]

13. Jakob, A.; Rüffer, T.; Schmidt, H.; Djiele, P.; Körbitz, K.; Ecorchard, P.; Haase, T.; Kohse-Höinghaus, K.; Frühauf, S.; Wächtler, T.; et al. Disilver(I) coordination complexes: Synthesis, reaction chemistry, and their potential use in CVD and spin-coating processes for silver deposition. Eur. J. Inorg. Chem. 2010, 2010, 2975-2986. [CrossRef] 
14. Tuchscherer, A.; Shen, Y.; Jakob, A.; Mothes, R.; Al-Anber, M.; Walfort, B.; Rüffer, T.; Frühauf, S.; Ecke, R.; Schulz, S.E.; et al. Lewis-base copper(I) formates: Synthesis, reaction chemistry, structural characterization and their use as spin-coating precursors for copper deposition. Inorg. Chim. Acta 2011, 365, 10-19. [CrossRef]

15. Yang, Y.; Huang, Q.; Payne, G.F.; Sun, R.; Wang, X. A highly conductive, pliable and foldable Cu/cellulose paper electrode enabled by controlled deposition of copper nanoparticles. Nanoscale 2019, 11, 725-732. [CrossRef]

16. Kwon, Y.T.; Kim, Y.S.; Lee, Y.; Kwon, S.; Lim, M.; Song, Y.; Choa, Y.H.; Yeo, W.H. Ultrahigh Conductivity and Superior Interfacial Adhesion of a Nanostructured, Photonic-Sintered Copper Membrane for Printed Flexible Hybrid Electronics. ACS Appl. Mater. Interfaces 2018, 10, 44071-44079. [CrossRef]

17. Chan, G.H.; Zhao, J.; Hicks, E.M.; Schatz, G.C.; van Duyne, R.P. Plasmonic properties of copper nanoparticles fabricated by nanosphere lithography. Nano Lett. 2007, 7, 1947-1952. [CrossRef]

18. Huang, C.-L.; Kumar, G.; Sharma, G.D.; Chen, F.-C. Plasmonic effects of copper nanoparticles in polymer photovoltaic devices for outdoor and indoor applications. Appl. Phys. Lett. 2020, 116, 253302. [CrossRef]

19. Gu, Z.; Shen, H.; Shang, L.; Lv, X.; Qian, L.; Zheng, G. Nanostructured Copper-Based Electrocatalysts for $\mathrm{CO}_{2}$ Reduction. Small Methods 2018, 2, 1800121. [CrossRef]

20. Luc, W.; Fu, X.; Shi, J.; Lv, J.J.; Jouny, M.; Ko, B.H.; Xu, Y.; Tu, Q.; Hu, X.; Wu, J.; et al. Two-dimensional copper nanosheets for electrochemical reduction of carbon monoxide to acetate. Nat. Catal. 2019, 2, 423-430. [CrossRef]

21. Kuroda, K.; Keller, P.; Kawasaki, H. Mild synthesis of single-nanosized plasmonic copper nanoparticles and their catalytic reduction of methylene blue. Colloids Interface Sci. Commun. 2019, 31, 100187. [CrossRef]

22. Gao, F.; Pang, H.; Xu, S.; Lu, Q. Copper-based nanostructures: Promising antibacterial agents and photocatalysts. Chem. Commun. 2009, 24, 3571-3573. [CrossRef] [PubMed]

23. Mahmoodi, S.; Elmi, A.; Hallaj-Nezhadi, S. Copper Nanoparticles as Antibacterial Agents. J. Mol. Pharm. Org. Process Res. 2018, 6, 1000140. [CrossRef]

24. Niavol, S.S.; Ghodsi, F.E. Effect of pH on the Properties of Nanocrystalline CuO Thin Films Deposited by Sol-Gel Process. Russ. J. Phys. Chem. A 2013, 87, 84-87. [CrossRef]

25. Syukri, T.; Ban, Y.; Ohya, Y.; Takahashi. Novel approach to deposition of copper thin films by dip-coating method. J. Mater. Sci. Lett. 2002, 21, 1449-1451. [CrossRef]

26. Szłyk, E.; Szymańska, I. Studies of new volatile copper(I) complexes with triphenylphosphite and perfluorinated carboxylates. Polyhedron 1999, 18, 2941-2948. [CrossRef]

27. Furukawa, Y.; Kaneko, A. Investigation of surface formation process of silicon molecular beam epitaxy by atomic force microscopy. CIRP Ann. 1999, 48, 453-457. [CrossRef]

28. Nakamoto, K. Infrared and Raman Spectra of Inorganic and Coordination Compounds, 6th ed.; John Wiley \& Sons, Inc.: Hoboken, NJ, USA, 2009; Part A 56-58, 217-220, part B, 276-282.

29. Sengar, B.R.S.; Narain, G. Magneto-chemistry and Infrared Spectra of Ammonia and Primary Aliphatic Amine Complexes of Copper(II) Chromate. Bull. Chem. Soc. Jpn. 1975, 48, 1087-1088. [CrossRef]

30. Uznanski, P.; Zakrzewska, J.; Favier, F.; Kazmierski, S.; Bryszewska, E. Synthesis and characterization of silver nanoparticles from (bis)alkylamine silver carboxylate precursors. J. Nanoparticle Res. 2017, 19, 121. [CrossRef]

31. Zakrzewska, J.; Uznanski, P. Synthesis and characterization of bis(amine)palladium(ii) carboxylate complexes as precursors of palladium nanoparticles. Dalton Trans. 2021, 50, 6933-6948. [CrossRef] [PubMed]

32. Melník, M. Mono-, bi-, tetra- and polynuclear copper(II) halogenocarboxylates. Coord. Chem. Rev. 1981, 36, 1-44. [CrossRef]

33. Mikuriya, M.; Yamakawa, C.; Tanabe, K.; Nukita, R.; Amabe, Y.; Yoshioka, D.; Mitsuhashi, R.; Tatehata, R.; Tanaka, H.; Handa, M.; et al. Copper(II) Carboxylates with 2,3,4-Trimethoxybenzoate and 2,4,6-Trimethoxybenzoate: Dinuclear Cu(II) Cluster and $\mu$-Aqua-Bridged Cu(II) Chain Molecule. Magnetochemistry 2021, 7, 35. [CrossRef]

34. John Wiley \& Sons. SpectraBase Compound ID=8A1dEqurmmH SpectraBase Spectrum ID=G4CBuKNSKtQ, (n.d.). Available online: https: / / spectrabase.com/spectrum/G4CBuKNSKtQ (accessed on 30 October 2021).

35. John Wiley \& Sons. SpectraBase Compound ID=Cz3wO46i3MG, (n.d.). Available online: https://spectrabase.com/compound/ Cz3wO46i3MG (accessed on 30 October 2021).

36. John Wiley \& Sons. SpectraBase, SpectraBase Compound ID=3IaXq9hN0c6 SpectraBase Spectrum ID=4PAsbe0uoOp, (n.d.). Available online: https:/ / spectrabase.com/spectrum/4PAsbe0uoOp (accessed on 30 October 2021).

37. John Wiley \& Sons. SpectraBase Compound ID=6i6hO8Z6rbg SpectraBase Spectrum ID=1HL91c6HmtV, SpectraBase, (n.d.). Available online: https:/ / spectrabase.com/spectrum/1HL91c6HmtV (accessed on 30 October 2021).

38. John Wiley \& Sons. SpectraBase Compound ID=4G3cv2HmDfG SpectraBase Spectrum ID=89U74D3zedG, (n.d.). Available online: https: / spectrabase.com/spectrum/89U74D3zedG (accessed on 30 October 2021).

39. Fuson, N.; Josien, M.-L.; Jones, E.A.; Lawson, J.R. Infrared and Raman spectroscopy studies of light and heavy trifluoroacetic acids. J. Chem. Phys. 1952, 20, 1627-1634. [CrossRef]

40. Shipman, S.T.; Douglass, P.C.; Yoo, H.S.; Hinkle, C.E.; Mierzejewski, E.L.; Pate, B.H. Vibrational dynamics of carboxylic acid dimers in gas and dilute solution. Phys. Chem. Chem. Phys. 2007, 9, 4572-4586. [CrossRef] [PubMed]

41. Höflich, K.; Jurczyk, J.M.; Madajska, K.; Götz, M.; Berger, L.; Guerra-Nuñez, C.; Haverkamp, C.; Szymanska, I.; Utke, I. Towards the third dimension in direct electron beam writing of silver. Beilstein J. Nanotechnol. 2018, 9, 842-849. [CrossRef] [PubMed] 
42. Nakamoto, K. Infrared and Raman Spectra of Inorganic and Coordination Compounds: Part B: Applications in Coordination, Organometallic, and Bioinorganic Chemistry, 6th ed.; John Wiley \& Sons, Inc.: Hoboken, NJ, USA, 2009; p. 118.

43. Gu, N.X.; Oyala, P.H.; Peters, J.C. Hydrazine Formation via Coupling of a Nickel(III)-NH2 Radical. Angew. Chem. Int. Ed. 2021, 60, 4009-4013. [CrossRef] [PubMed]

44. Jakob, A.; Rüffer, T.; Ecorchard, P.; Walfort, B.; Körbitz, K.; Frühauf, S.; Schulz, S.E.; Gessner, T.; Lang, H. Phosphane Copper(I) Dicarboxylates: Synthesis and Their Potential Use as Precursors for the Spin-coating Process in the Deposition of Copper. Z. Anorg. Allg. Chem. 2010, 636, 1931-1940. [CrossRef]

45. Bräuer, B.; Zahn, D.R.T.; Rüffer, T.; Salvan, G. Deposition of thin films of a transition metal complex by spin coating. Chem. Phys. Lett. 2006, 432, 226-229. [CrossRef]

46. Syukri; Terazawa, T.; Ban, T.; Ohya, Y.; Takahashi, Y. Dip Coating of Metal Films from Metal Acetate-Acetol Hydrazone System, Ceram. Trans. In Proceedings of the International Conference on Ceramic Processing Science Meeting, Nagoya, Japan, 15-17 May 2000; 2001, Volume 112, pp. 329-334.

47. Theivasanthi, T.; Alagar, M. X-Ray Diffraction Studies of Copper Nanopowder. Arch. Phys. Res. 2010, 1, 112-117. [CrossRef] 